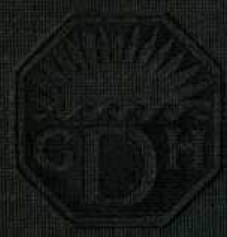



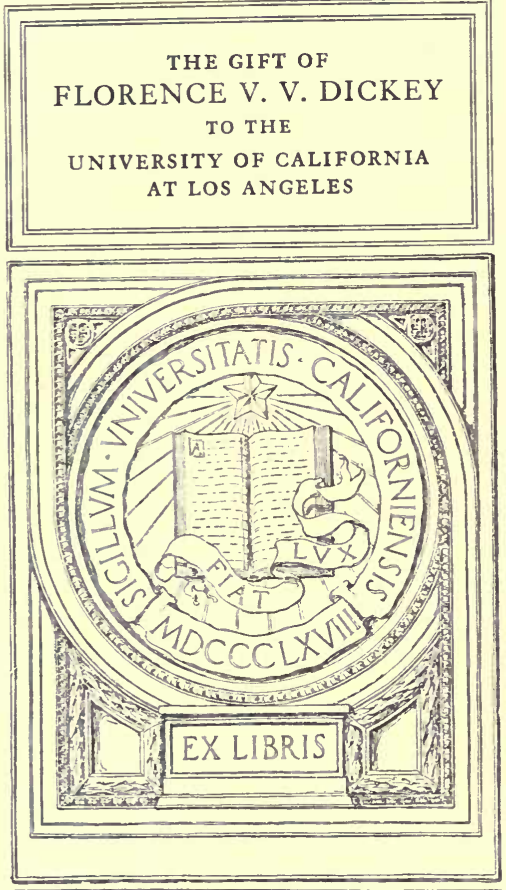

THE DONALD R. DICKEY LIBRARY OF VERTEBRATE ZOÖLOGY 



\section{WILD LIFE IN THE TREE TOPS}






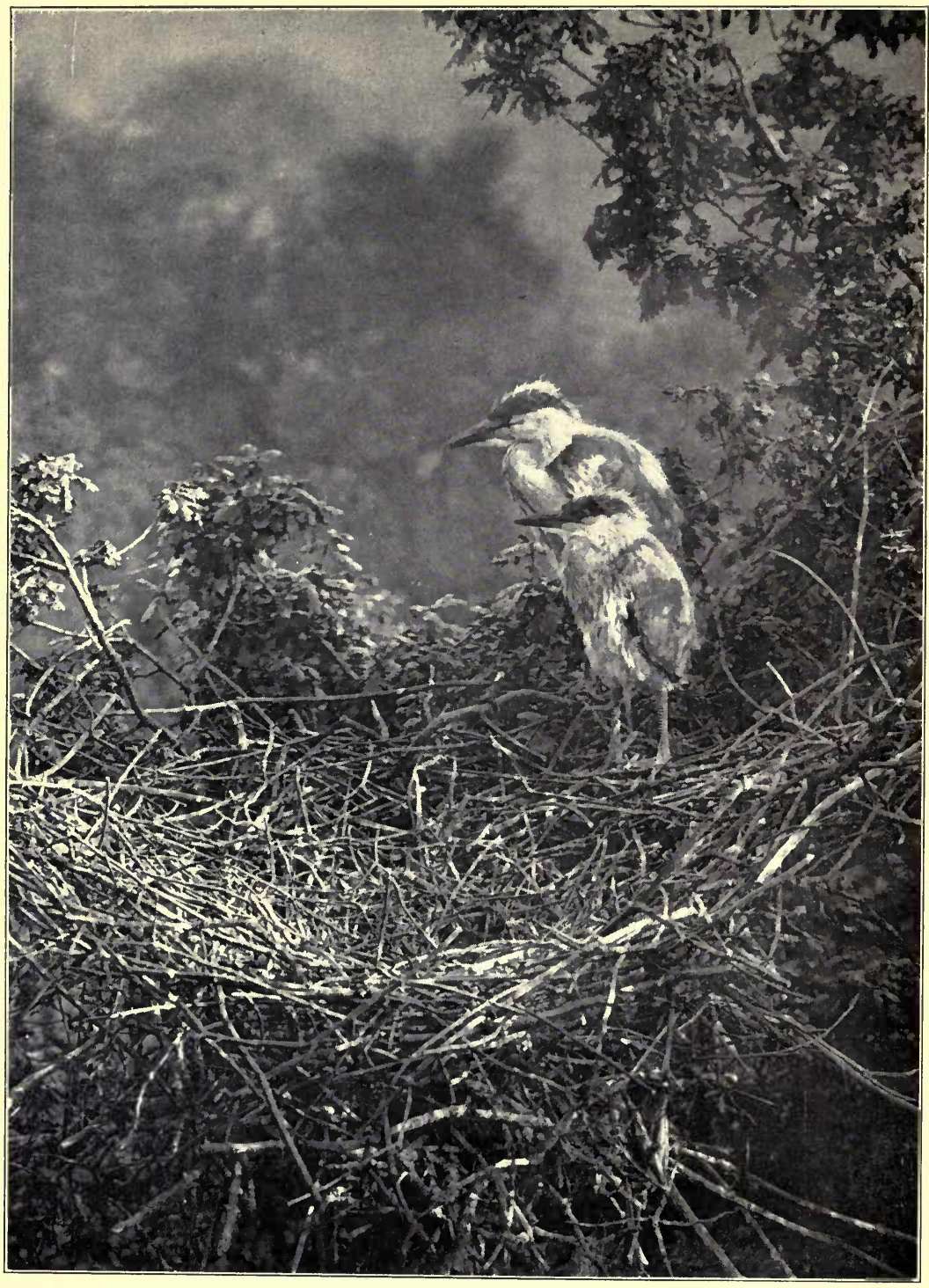




\section{WILD LIFE \\ IN THE TREE TOPS}

\section{By \\ CAPT. C. W. R. KNIGHT \\ M.C., F.R.P.S., M.B.O.U.}

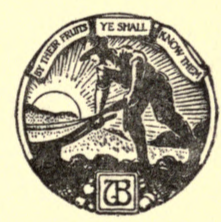

FIFTY-THREE ILLUSTRATIONS FROM PHOTOGRAPHS TAKEN BY THE AUTHOR

GEORGE H. DORAN CO., NEW YORK THORNTON BUTTERWORTH LIMITED I5 BEDFORD STREET, LONDON, W.C.2 
Published . . . Nov. 1921

Second Impression . . Jan. 1922 


\section{CONTENTS}

CHAP.

PAGE

I A Rookery IN Spring .

II The Buzzards of the Doone Country $\quad . \quad \ldots \quad . \quad . \quad$. 27

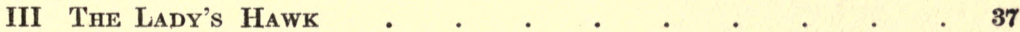

IV In the Depths of a Fir Forest . $. \quad . \quad . \quad . \quad . \quad . \quad$. 45

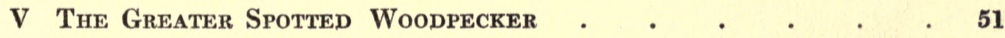

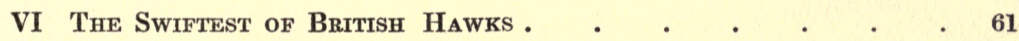

VII Two Brown Owls $\quad$ •

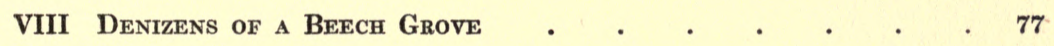

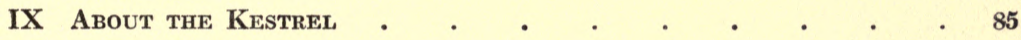

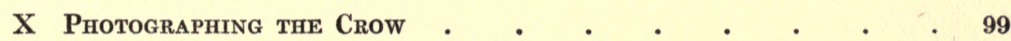

XI Concerning a Sparrow Hawk Family . $\quad . \quad$. $\quad . \quad$. 107

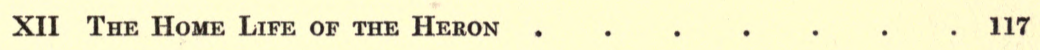

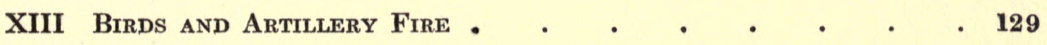

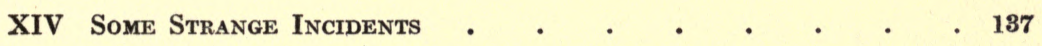




\section{LIST OF ILLUSTRATIONS}

FACING

PAGE

The Rabbit's Contribution (see p. 144) . . . . Frontispiece

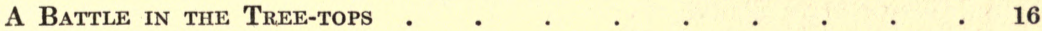

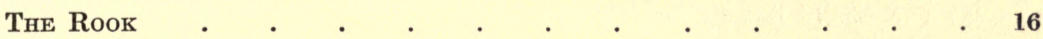

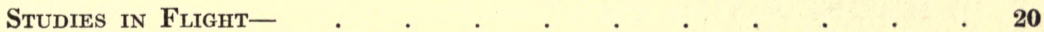

(a) A rook " banking."

(b) "The throw-up" of the kestrel.

The Rook with her Clamouring Family . . . . . . . . 24

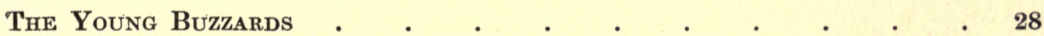

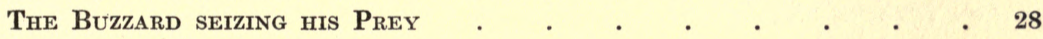

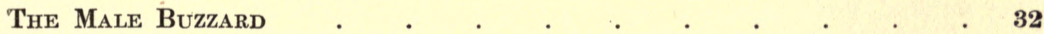

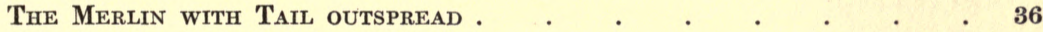

The Merlin Pursuing her Quarry. . . . . . . . . . 40

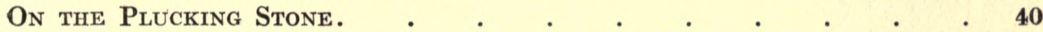

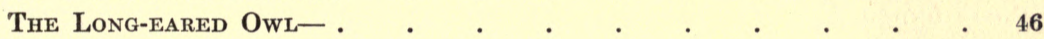

(a) Suspicious.

(b) Thoroughly alarmed.

A Long-eared Owl and her Single Youngster- $\quad . \quad$. $\quad . \quad 48$

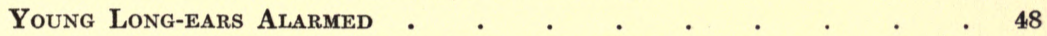

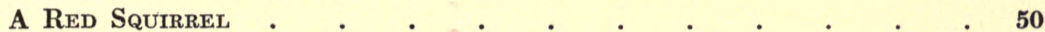

The Great Spotted Woodpecker . . . . . . . . . 52

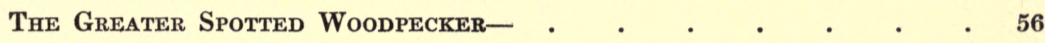

(a) On the wing.

(b) Climbing.

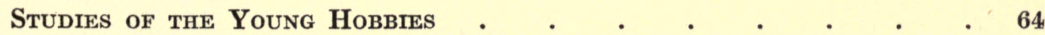

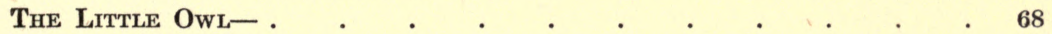

(a) Mature.

(b) Immature.

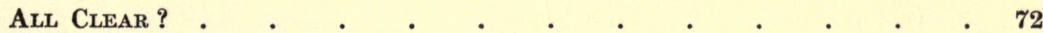

Young Tawny Owls in a disused Magpie's Nest . . . . . 74

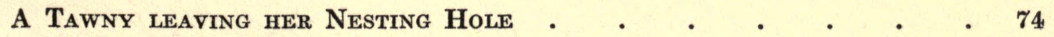

A Young TAWNy 
The Green Woodpecker

The Noctule's TeEth

Three Female Noctules and their Young . . . . . . . 84

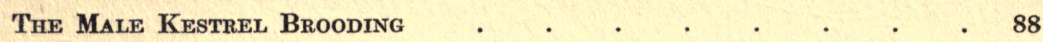

Newly Hatched Young Kestrels . $\quad . \quad$. $\quad . \quad . \quad . \quad . \quad . \quad 88$

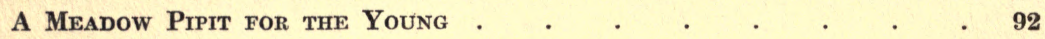

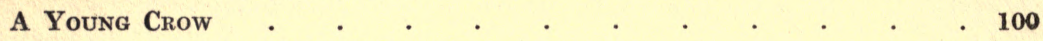

A Crow's Strange Nest Materials $\quad$. $\quad . \quad . \quad . \quad . \quad . \quad . \quad$. 100

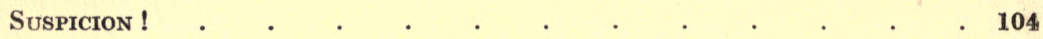

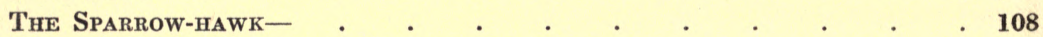

(a) The family line-up for the meal.

(b) At a later stage they feed themselves.

The Sparrow-hawk's Wild Eye . . . . . . . . . . 112

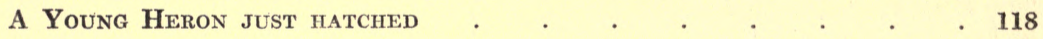

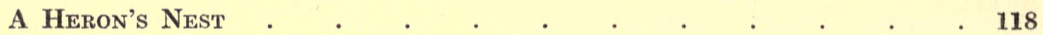

With her Yellow Eye fixed on the O.P. . . . . . . 120

Heron feeding her Young . . . . . . . . . . . . . . 124

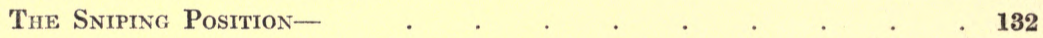

(a) The swallow's nest.

(b) The view through the loophole.

The Nest of the St. Eloi Golden Oriole . . . . . . . 134

Rooks under Fire. . . . . . . . . . . . 134

The "Scruff" of the Young Stoat . . . . . . . . 140

From the Stoat's Larder . . . . . . . . . . 140 


\section{PREFACE}

T $\mathrm{N}$ the following pages $\mathrm{I}$ have endeavoured to set forth some of my observations and experiences whilst studying those birds-and mammalswhose habit it is to frequent the upper branches of our trees. These dwellers among the tree tops held-even in my school days-an overwhelming fascination for me ; and in those days my ability to climb seemingly inaccessible trees often stood me in good stead where the collecting of eggs was concerned. On many occasions I was asked to climb to the nest of some bird-perhaps a member of the Crow or Hawk tribe-because he who had found it was not equal to the task; and I often noticed that, in comparatively good collections the eggs of such birds were not represented.

And since it seems that our tree-nesting community generally are to-day somewhat neglected by the Natural History photographer, I hope that the results of my efforts as contained in this volume may prove to be of interest to all those to whom our wild creatures are a source of pleasure.

I have set down nothing concerning the birds and mammals which I have studied that has not come within my own personal experience, and have not quoted the views and beliefs of others without specific mention of the fact.

Let me avail myself of this opportunity of expressing my thanks to those who have so generously allowed me to construct " observation posts" on their land; for without such hiding-places the photographs with which the book is illustrated could never have been secured. I should also like to thank those others who have so cheerfully encouraged me in my frequent moments of exasperation and despondency.

\section{Park Point, \\ Bessels Green,}

SEVENOAKS.

September 30, 1921. 


\section{INDEX}

A

Ants, 81

B

Bat (noctule), 52, 82-84

Beetles, 70, 85

Beetles (water), 127

Bird catchers, 107

Blackbird, 71, 109, 133

Bullfinch, 72

Buzzard, 18, 27-35, 38, 62, 71, 91

C

Castings, 16, 35, 127

Chicken, 64, 67

Crossbill, 13

Crow (carrion), 16, 25, 33, 38, 63, 87, 92, 99-106, 113, 139

Cuckoo, 109

D

Dove, 109

Dove (stock), 50, 70, 77, 143-144

E

Eagle (Golden), 27, 29

Earthworms, 85

Eels, 124, 126, 127

F

Falcon (Peregrine), 14, 18, 19, 27, 38, 64, 68, 117

Falconry, 19, 38, 42, 62, 117, 120, 133

Fish, 119, 127

Fish, flat, 127

Fish, gold, 127

Frog, 72-85
G

Golden Oriole, 129-132

Goshawk, 28

Grasshopper, 85

Great Tit, 57, 115

Greenfinch, 47, 71

Grouse, 41

H

Hack (flying at), 64

Haggard Hawk, 95

Heron, 16, 35, 92, 113, 117-128, 142-144.

Hobby, 27, 37, 40, 46, 61-68, 92,99

\section{J}

Jackdaw, 48

Jay, 44, 45, 49, 109, 132

K

Kestrel, 16, 18, 27, 28, 29, 37, 40, 41, 43, $46,62,65,68,70,85-97,133$

Kite, 28, 31

L.

Lady's Hawk, 37-44

Lark, 41, 42, 67, 89

Lizard, 29

M

Magpie, 34, 129, 133

Mallard, 42, 140, 142

May-bug, 67

Meadow Pipit, 41, 85, 89

Merlin, 37-44, 62, 72, 107

Moles, 29, 71, 74, 127

Moorhen, 130 
Mouse, 71, 74, 85

Mouse (Field), 71,90

$\mathbf{N}$

Nightingale, 129, 132

Night-jar, 109

Nuthatch, 57, 81-82

O

Observation post, 20

Osprey, 28

Owls, 39

Owl, Barn, 46, 70, 73, 140

Eagle, 18

Little, 27, 46, 52, 69, 75, 133

Long-eared, 13, 46-49, $\gamma 1$

Tawny, 46, 69-75, 77

\section{$\mathrm{P}$}

Partridge, 27, 41, 43, 69, 72, 86, 132

Pheasant, 69, 86

Pigeon, 43, 92

Plover, 41, 43, 48

R

Rabbit, 28, 31, 32, 33, 71, 74, 144

Rat, 71, 74

Raven, 99, 103

Redshank, 127

Robin, 71, 137-138

Rook, 13-25, 39, 87, 99, 133-135, 140
Shrikes, 16

Shrimps, 177

Sparrow, 71, 92, 96, 109

Sparrow-hawk, 29, 37, 41, 42, 43, 45, 46: $48,68,92,107-116,132,138$

Squirrel, Grey, 50

Red, 45, 49, 50

Starling, 52, 71, 85, 92

Stoat, 18, 141-142

Stork, 13

Swallow, 63, 129, 131

Swift, 67

\section{$\mathbf{T}$}

Thrush, 39, 72, 91, 109, 132, 142

Missel, 48, 70, 72, 139

\section{$\mathbf{V}$}

Vole, 85

Vole (water), 72, 127

\section{W}

Wagtail, Pied, 137-138

Whitethroat, 111

Woodpecker, Greater Spotted, 51-59, 78, 81-82

Green, 51, 58, 78-81, 109, 142

Lesser Spotted, 78, 81-82

Woodpigeon, 45, 109, 130 


\section{CHAPTER I}

\section{A Rookery in Spring}

$\mathrm{P}^{\mathrm{n}}$ ROBABLY the most familiar figure among the tree-top dwellers of these Islands is that of our friend the Rook ; which bird is indeed so generally distributed and so obvious as to need no detailed description here.

Most of us, too, will have noticed the clustered nests, particularly during the winter months, when, silhouetted against the sky, they stand out clearly among the then leafless branches.

There is always a certain romantic attraction about a Rookery, even as seen from 'terra firma,' and a distant view of the jolly rooks as, after an absence of some eight months, they return to repair the remains of last year's nests, generally arouses, at least amongst the youthful population, something of the enthusiasm that greets the coming of the Stork on the continent.

In most districts the Rook is the first of our birds to commence its building operations. Occasionally, and almost before we have realized that winter has left us, a report may come that the eggs of a Crossbill or Long-Eared Owl have been discovered; but, generally speaking, the bulky structures which the Rooks put together with such noisy argument are the first indications that yet another nesting season has arrived.

Once the building has commenced in earnest, the tree-tops afford a spectacle which, by reason of the comings and goings and the curious antics involved, can hardly fail to attract and arrest attention.

A Rook will put himself to immense trouble in carrying, often from a considerable distance, a stick-one might sometimes even call it a small branchwith which to help strengthen the foundation of a nest. It is by no means plain sailing, for obstacles will assuredly be encountered; an adverse wind may be blowing; whilst frequently the chosen branch will be awkwardly shaped, with side growths that make it difficult to control. Eventually, however, the nest site will be reached, with, in all probability, an adoring if impatient mate to help him in his troubles ; and then, with what quaint beak thrusts and tuggings will the new acquisition be finally fixed in position.

No sooner is this satisfactorily accomplished than the Rook is off once more for fresh material. As a rule, although the lower branches of his own 
tree would often seem to serve his purpose quite admirably, the Rook prefers to gather his sticks and twigs from some particular tree in the neighbourhood, which for some reason, impossible to determine, has attracted his fancy. He has, moreover, a nice choice in twigs, and having reached the selected tree he will hop from branch to branch, peering this way and that, until he spies what he considers to be the most suitable one.

He sidles out along the branch, looks at it closely, makes up his mind and seizing it in his beak, pulls and twists until, with heaving shoulders and halfclosed eyes, he contrives to wrench it free.

Then home once more, and back, and home again.

How intently does each pair of Rooks work to perfect their future home, and with what a pompous air do they turn all comers from what they consider to be their own particular area!

Sometimes a pair of Rooks will sit for hours together by their half-built nest, apparently dreaming away the time, and seeming in no hurry to finish the work; but, rather, completely satisfied with the feeling that the site has been decided upon, and that actual building has begun.

A colony of Rooks on a balmy March morning, softly calling to one another amongst the nests in the tree-tops, high above the primroses which carpet the sweet-smelling earth beneath, may perhaps convey to the casual observer the impression of a peace-loving, easy-going community. Yet sociable as they are, the trees witness some lively struggles for mastery amongst them.

Sometimes, for some unaccountable reason, one Rook will suddenly make an attack on his neighbour's unoffending wife as she sits complacently upon her nest, and such a scuffle and squawking will ensuc as to suggest that both rooks are being put to death-to say nothing of the smashing of any eggs that might be in the nest.

The husband of the unhappy victim of this onslaught, chancing to be leisurely returning from some foraging expedition, suddenly quickens his pace : his keen eyes have detected that there is trouble at home, and dashing forward he sweeps into the tree with the swerving purposeful action of a Falcon closing on her quarry. In an instant he has seized the intruder with beak and talons, and whilst the pair of them, firmly locked in each other's claws, come fluttering and squalling down through the branches, the female who was thus unceremoniously attacked, calmly resumes her duties as though nothing untoward had happened.

And how human they are! One pair, perhaps resenting the proximity of those in the next nest, finds some excuse for the exchange of a few pleasantries; and give vent to their feelings by advancing towards their neighbours with uplifted wings, raised hackles, and the most awe-inspiring caws that they can produce; each of them apparently urging on his mate to go in and set the brave example. 
Meanwhile the neighbours put up a good show by standing firmly with half-spread wings and open beaks : trying, it would seem, to bluff the aggressors into believing that they will hold on to the last.

One of the attackers jabs wildly with his beak in the direction of the enemy -upon which all eaw frantically; the other takes half a pace forward to the loud applause of his mate; while the besieged, by firmly holding their ground, seem to demoralize the besiegers to such an extent that no decisive result is attained. And so, with a good deal of wing-flapping and smoothing of ruffled feathers, the battle comes to an inglorious end. No blood has been spilt, but every one seems satisfied.

While all this is going on, a Rook occupying a flat below goes cheerfully about her business, neither she, nor any of the others in the vicinity taking the least interest in the uproar.

When, however, later in the season, the rival claims have been adjusted, and the females are sitting upon their greenish blotched eggs, an atmosphere of peace and serene content pervades the colony. The caws that emanate from the branches about the nests seem to be the sleepy conversation of a satisfied people, and every now and again the faithful husbands may be seen flying into the trees, each settling on his nest, or some branch adjacent to it, and affectionately poking food down the throat of the cawing female; which operation accounts for the curious gulping sound which sometimes intercepts a prolonged 'caw-w-w.'

The delight of the female as she receives the little gift is very obvious, for besides such verbal expression of her pleasure, she flutters her half-opened wings in a quivering way, just as a young bird does when taking food from the parent.

Sometimes she is so overcome with joy at the return of her mate-or the possibility of more food-that unable to wait patiently upon the nest, she flutters from branch to branch towards him, and with wide-open beak awaits the expected meal.

Such food is almost invariably collected from the pasture and arable land in the vicinity of the Rookery, and is composed almost entirely of larvæ and insects. So anxious are the Rooks to secure these delicacies that they will settle upon and examine the newly turned earth in the wake of a plough; and in fact, in hard weather, when they are pressed for food, they will often settle within a few fest of the man guiding the plough, and instances are on record of the Rooks having been ploughed under in their cagerness to secure some tempting morsel.

Towards the middle of March, or early in April, the majority of the Rooks have completed their nests. In due course from one to six eggs are laid, the most usual clutch being four or five-though it is by no means uncommon to find but a single nestling hatched. 
A rather quaint theory which has been put forward by an ardent presentday oologist-who also happens to be a somewhat poor climber-is that the most vigorous Rooks select and monopolize the highest points of the trees for the nesting sites-so that the weakly down-trodden Rooks have to be satisfied with the lower and more accessible branches. Consequently the largest clutches are at the extreme tops of the trees! The oologist therefore who is a poor climber-or who suffers from vertigo-must needs content himself with a poor show of Rooks' eggs! The writer's experiences do not confirm this theory.

The ground beneath a Rookery is littered with the sticks which have been dropped by the birds during the scuffles involved in the business of nest-building, as well as with the pellets which the birds have cast. The latter generally consist of grasses, beetles' cases, fur, and so forth, and afford good evidence of the Rook's taste.

It is perhaps not generally known that Rooks, Crows, Herons, and Shrikes share with the Hawks and Owls the ability to thus get rid of indigestible matter. And in order to enlighten those who are not acquainted with this habit, it might be well to explain here exactly what a casting is, and how a casting is produced-for castings will be referred to in later pages, and it will be well to understand the exact meaning of the term.

A casting or pellet, then, is composed entirely of the indigestible portions of recent meals, and is thrown up and ejected through the beak, generally on the morning following the day on which the food was consumed.

If, for instance, a Kestrel should devour, let us say, some mice, on a particular day, it will, early the next morning, suddenly commence to work its head and neck about in an uneasy strained sort of manner; and with lowered head and open beak will strive to throw up the casting. In a few seconds its efforts are successful, and the pellet or casting which, in the case of a Kestrel, is usually about the size and shape of an acorn, drops to earth. Upon examination the casting will be found to consist of the fur and whiskers of the unhappy mice of yesterday. By examining such castings, one may form a very fair idea of what the bird concerned has been feeding on.

Rooks cling to their breeding-sites with remarkable tenacity. Year after year they return to the same clump of trees ; in fact, their constancy in this respect is so marked that their presence is often associated with the fortunes of the family whose permanence has, so to speak, coincided with their own.

It is an ill day for the Hall, say the village wiseacres, when at the nesting season the Rooks fail to put in an appearance, and until they establish themselves bad luck will overtake the place, and will continue.

Sometimes, however, tradition is openly defied, and the Rooks given notice to quit.

The following instance may serve to show how difficult it may be to 


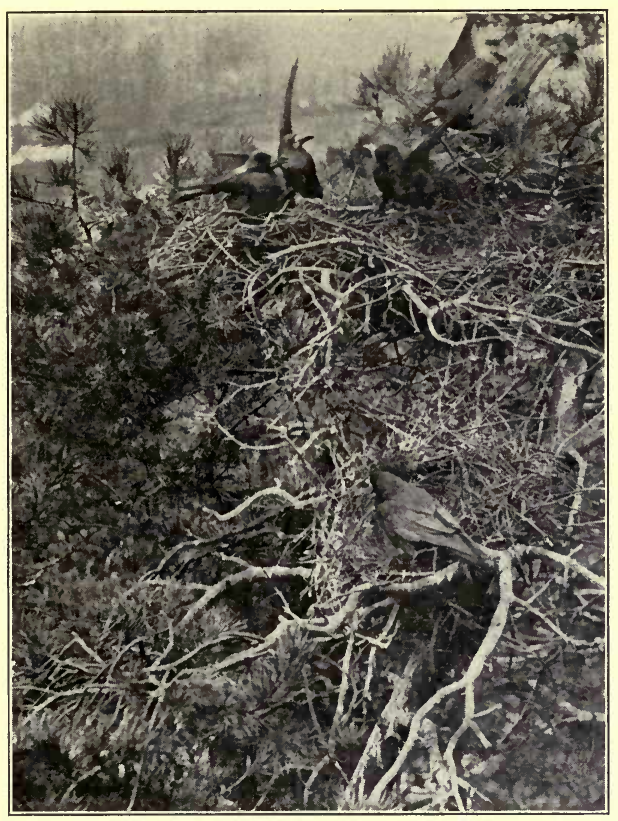

A BATTLE

IN THE

TREE-TOPS
THE ROOK

[Showing the absence of feathers at the base of the beak.]

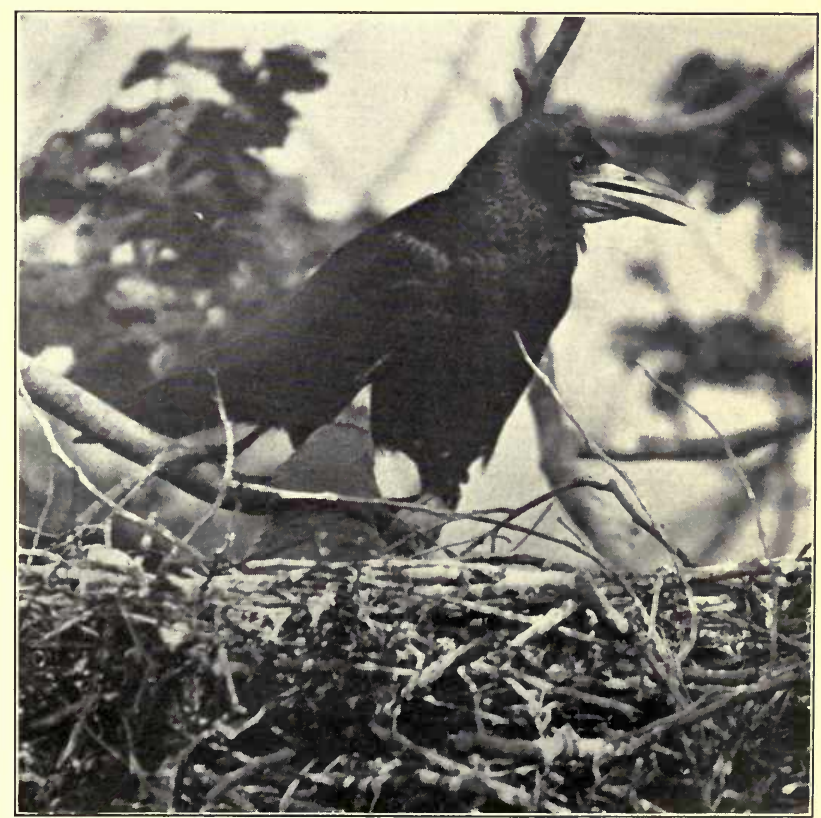


persuade the members of a Rookery to nest anywhere but in their time-honoured clump of trees.

A farmer on whose land was a long-established Rookery, decided that, owing to the raids which the birds were making upon his newly-sown corn, he would have no more of them, and detailed a man, armed with an ancient though formidable shot-gun, to stand under the trees; and instructed him to shoot any Rooks that might come within range.

Day after day the spasmodic bangs of the gun might be heard from the distance; day by day some unfortunate Rook, braver than the rest, would fall a victim to the shooter's patience; and day by day the mangled bodies of the dead Rooks, littered about under the trees, increased in numbers. Weeks passed and still the Rooks, hanging about their trees, refused to commence nest-building elsewhere. Occasionally one or two would alight on the familiar branches, only to pay the full penalty for their temerity, and yet they refused to leave.

At last, however, the watch below was relaxed, and the Rooks, feeling that the period of waiting was over, commenced the business of nest-building with feverish energy.

Where one evening there had been not a single new nest, there were, the following morning, the foundations of between fifty and sixty being run up at lightning speed. Little time there was for squabbling or intervals of peaceful rest, so busy were the Rooks on the serious business of home-construction.

A few days later the man with the gun resumed action. Soon the ground was thickly strewn with the remains of the birds. Caught up in the branches beside some of the nests the bodies of Rooks hung listless. And still the intermittent banging of the gun could be heard.

At length such terror was instilled into the hearts of the surviving Rooks that they were driven to betake themselves elsewhere, and the man with the gun at last relinquished his position under the silent remains of last year's nests.

On May 10 th of that year it was found that a solitary pair of Rooks had stuck indomitably to the ancestral haunt, and had laid three eggs in a nest surrounded by the deserted homes of dead or fugitive relations.

But if undisturbed, the Rooks, by the middle of May, would be engaged in feeding their young-many of which would be by this time almost fully grownand might be seen making constant journeys between the Rookery and the feeding-ground.

When the young Rooks are able to leave the nests and take short flights to the surrounding trees, it is a common practice for the owner of the place to organize a 'Rook-shoot,' when either guns or rifles may be utilized in the process of thinning out the young Rooks. To what degree this may be termed 'sport' is an open question; certain it is, however, that it does not 
prevent the Rooks from returning to the same nesting-site in the following year, and the possibility of Rooks becoming a serious nuisance to the agriculturist must not be lost sight of.

Few birds are more wary. A flock of them feeding in a field will appear to be so busily engaged as not to mark your passing ; but, stand for a moment or raise your stick to your shoulder as you would a gun, and in a moment the whole flock is on the wing with loud and angry remonstrance.

This wariness-perhaps not unmixed with curiosity-accounts for the fact that if a stoat be gambolling or hunting on the Rooks' feeding-ground, the birds will collect in a rough circle around it, and spend a considerable time in fluttering into the air, advancing a few yards towards the object of their apprehension-or curiosity-and retiring with spasmodic leapings and flutterings if it should chance to advance towards them.

This characteristic is sometimes taken advantage of by those who, for some reason or other, wish to rid the district of some of its Rooks. Instead of a stoat, a tame ferret is used as a decoy, and the little animal, tethered to a spot frequented by Rooks, seldom fails to attract the first flock that chances to be passing. The Rooks turn in their flight, and settling in the same manner as when a stoat is espied, form an easy mark for the gunner who is meanwhile lying in wait.

A large bird of prey might-and has been-utilized to the same purposebut in this case there is no question as to why the Rooks are attracted. They cordially detest-for instance-an Eagle-Owl or a Buzzard, and vent their feelings by ' mobbing' the intruder ; that is by making a series of sharp swoops at his head! It is indeed an extraordinary sight to see a flock of Rooks stooping, one after another, at their ofttimes quite imaginary enemy.

Should a modest Kestrel approach the Rookery too closely he will be quickly driven off by the Rooks; who, issuing forth in a crowd, will so harry the quite innocent little hawk as to prompt him to put on his best pace and quit the district without delay.

Even the lordly Peregrine is sometimes thus ignominiously pursued by the vulgar Rook-and the question at once arises as to how the Rooks can possibly tell that, at the moment, the noble Falcon is not 'out for blood'; for in the ordinary course of things, to merely catch sight of a Peregrine creates such feelings of dread within the Rook's breast as to send him flying headlong to the nearest cover.

Apropos of this point the following account may be of interest to the readers of these lines.

One stormy April evening, whilst watching with a pair of glasses the goings on in a Rookery in the West of England, the writer was asked by a mounted passer-by if a Peregrine had been seen. A hawking party was out, and following a long, high flight, one of the Falcons in pursuit of a strong Rook 
had literally 'disappeared into the blue,' and had last been seen some halfmile north of the Rookery.

Knowing something of the art of Falconry, the writer promised to try and take her up if she should put in an appearance-or at least report her whereabouts if he should see her take perch to roost for the night.

About an hour later he was attracted by the extraordinary behaviour of the Rooks, who suddenly rose up in a great cawing mass above the trees, only to retire, equally suddenly, amongst the branches again. And then the cause of their unrest, in the shape of the lost Falcon, hove in sight. As she passed overhead two things were obvious, one, that she was a trained hawk, for her bells could be heard quite clearly, the other, that she had recently killed and fed up; her protruding crop was sufficient evidence of that.

How serenely she sailed along!

No wonder, soliloquized the writer, that the Rooks withdrew so hurriedly into the cover of the tree-tops! For he knew how exceedingly quick they are to avail themselves of any cover, even when they see the Falcon sitting on the Falconer's fist.

Right overhead she passed, her bells tinkling, her jesses trailing behind -what a glorious bird!

And then a strange and a totally unexpected thing happened. Hardly had she passed over the Rookery than a dozen or so Rooks-feeling perhaps more confident when acting collectively, suddenly dashed out from the trees, and treating this most noble of birds as though she were a common Owl or Buzzard, commenced to mob her in the cheekiest manner.

So implicit was the writer's faith in the Falcon that he fully expected her to turn and scatter the rude mob. His feelings of disappointment can be better imagined than described, when it is told that not only did the Falcon shift and twist to avoid the stoops of the Rooks, but that she even began to scream vociferously!

Yet watchful, clever-and at times even brave-as the Rook undoubtedly is, he is nevertheless on occasions extremely stupid-or unjustifiably confiding in his own kind. Watch him, for instance, hard at work labouring backwards and forwards between the nest and the tree from which he gathers his sticks. So intent is he on his work that he does not notice that each time his back is turned a covetous Rook from a neighbouring nest will stealthily creep forward and commence to prod and pull at his hardly-won pile. Nor indeed is it essential that his back should be turned, for sometimes the robbery takes place beneath his very nose-or perhaps one should say 'beak'-without the least notice being taken.

$\mathrm{He}$ merely adjusts the newest find and straightway starts off in quest of another.

The question as to how accurate observations of the ways of such birds 
as Rooks can be carried out, may have already arisen in the mind of the reader.

Of course Rooks are exceedingly common birds, and birds moreover that love to nest in the vicinity of human dwellings-and usually do so before the leaves are out to hide them and their bulky homes. And yet it is not an easy matter, even from a convenient top-floor window in the neighbourhood of a Rookery, to get a really clear, unobstructed view of what is taking place in the various nests. There are so many twigs and branches to obstruct anything but an overhead view; and one can hardly contemplate hiring an observation balloon!

After many years of experience, the writer has come to the conclusion that there is one way, and one way only, of studying intimately the habits of the tree-top denizens; and that is by building high up among the branches, and at a point overlooking the selected nest, an observation post, into which when the time for action arrives, the observer, possibly with his camera, may retire, and whence he can observe without himself being seen.

It need hardly be said that such an observation post, which may be constructed of sacks, old tablecloths, 'shoddy bags,' and so on-is not built in a day-nor in a week.

Rooks, as we have already noted, are very wary birds, and should such a huge structure appear too suddenly in the midst of their homes, they would, without doubt, leave their eggs and young, once and for all-with direful results.

So the building of the observation post, if catastrophes are to be avoided, must be very gradual, and will cover a considerable period.

When the foundation stone of the observation post-in the shape of a piece of sacking, some two feet square-is first placed in position, the Rooks take some little time in overcoming their innately suspicious natures, and in assuring themselves that the piece of sacking, flapping idly in the wind, is not a fresh kind of trap. But at length, encouraged no doubt by the complacency of their more distant neighbours, they ultimately take their courageas it were-in both feet, and hop gingerly on to the nest : as a rule, only to shoot upwards and backwards, as though they have accidentally dipped their toes into boiling water.

At length, however, they settle down, and the following morning generally finds them utterly careless of the flapping canvas.

A day later another piece of sacking is added to the first; and so on, until at the end of three weeks we have quite a respectable semblance of a hiding-place, for by this time the sides are tied together; there is sufficient loose sacking hanging down to hide the feet; and the whole affair is most artistically camouflaged with dead branches, sprays of elder, and handfuls of grass and rushes from the dyke hard by. 


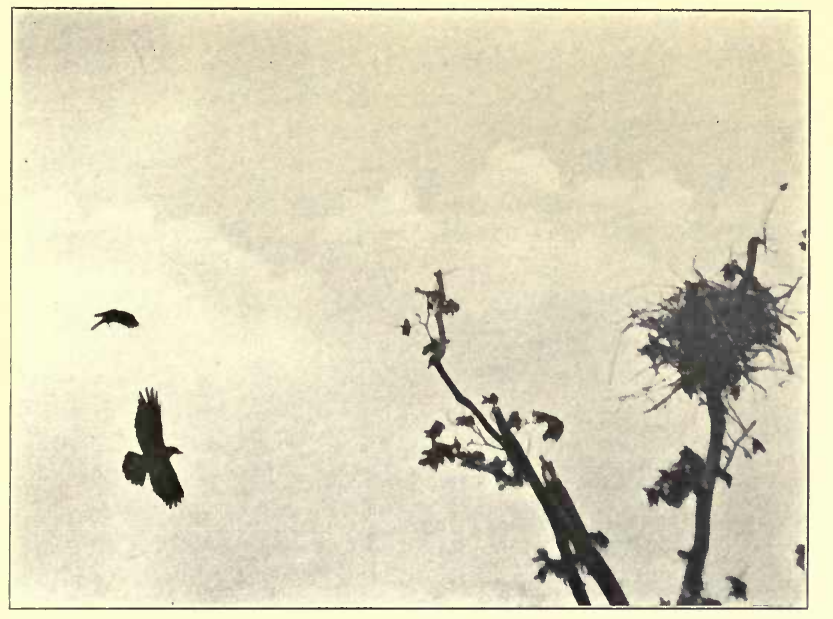

A ROOK "BANKING" ANI)

"THE THROW.UP" OF THE KESTREL

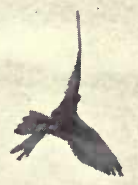


All that is now needed is one more shoddy bag to serve as a roof, a little platform affair on which the camera may be fixed, and some black muslin.

At this stage in the proceedings there is one danger to be guarded against, and that is the possibility of the Rooks returning while work in the observation post is in progress, for in all probability any chances of success would be doomed if the Rooks should return to find a human being dallying so close to their homes.

So it is necessary to devise some means of keeping them away during the time that the observation post is being completed.

All of which sounds simple enough; but, as a matter of fact, the business of collecting sacks and shoddy bags, of dragging camouflage branches, and so on, to the foot of the tree, and of hauling them all to the proper elevation-to say nothing of fixing them in the desired position, is really at times somewhat trying. For when they, or some of them, are at length lodged in the fork of some swaying branch, it is with the utmost difficulty that one hangs on with one hand, and attempts to tie up sacking, or hammer in a nail with the other.

By building the observation post thus gradually, one not only lessens the chance of scaring the Rooks, but spreads the hateful task over a longer period; nevertheless the waves of hopeless exasperation which are apt to overcome one at such times are never wholly avoided.

But at length the observation post is completed. The roof does not need camouflage of any kind, for almost resting upon it are no less than four Rooks' nests, three of which by this time contain fair-sized young ones. Without doubt one could easily touch an old Rook by making a hole through the bottom of her nest. But it would be a senseless thing to do.

The day having arrived then, when close-range observation and photography of the Rook is to be attempted, we-the writer and a companion-set out for the Rookery.

It is essential in such a case to have a companion to accompany one to the Rookery, to stand by until all is in readiness, and to leave as noisily and ostentatiously as possible; for otherwise the Rooks would in all probability reason out the fact, that if some one ascended the tree, disappeared, and has not since descended, then that some one must be still in the tree. This undesirable state of affairs is perhaps obviated by one's companion endeavouring to keep the attention of the Rooks concentrated on himself. In his efforts to attain this end, he throws his hat in the air, shouts, and performs other queer antics.

During the past summer a friend of mine who was carrying out this part of the work with extraordinary energy, was much embarrassed to suddenly find that he had a large and deeply interested audience watching him! Doubtless they thought him mentally deficient. 
Even from a distance the observation post looms large and clumsy, and we wonder whether the local populace will imagine it is an enormous rook's nest or part of a derelict Zeppelin. In any case the rooks seem to ignore it, and we are delighted to notice as we draw closer that 'our' nests are attended by the old birds.

Our arrival, however, seems to be much resented; the whole colony of Rooks rising in the air and circling above us with angry caws of remonstrance; their shadows dancing the while upon the meadow below.

No time is to be lost, for it is unwise to keep the birds from their nests for any length of time; and to the distant accompaniment of wild shouts from my companion, who is busy throwing his hat up and chasing it, the journey to the observation post is commenced.

The trees are elm, and consequently too much confidence must not be placed in their thinner limbs. Still, by keeping close to the trunk there is not much fear of an accident, and with a rope trailing behind, by which the camera may be hauled up, the observation post is ultimately reached.

In order to enter it, one has to reach up into its interior with one hand, grasp a stoutish branch which serves as a seat, and haul oneself high enough to get a footing on a convenient branch. The camera is then hauled up and fixed in position, and the word given to the hat thrower to go away, and return in four hours' time. These instructions have to be repeated some five or six times, as owing to a stiffish breeze which is blowing, it is impossible for him to hear a word of what is being said ; and it is only when he at last stands immediately beneath the observation post and listens with his head on one side that he understands what is required.

And now that all is in readiness we can lean back and take things easily -for a while. There is a wonderful light to-day, but rather too much wind. Through a tiny peep-hole in the sacking we can see the form of our companion, dwarfed by distance, slowly making its way over the cornfield towards the farm on the edge of the marsh.

But in the meantime, how are the Rook families faring? Immediately opposite to us as we sit on the branch, and at the same level as the head, is an opening in the canvas some six inches broad by one inch high, over which black muslin has been stitched. It is quite a convenient idea for watching the Rooks without any possibility of their seeing through into such a dark interior.

There are two nests under observation, about four feet from one another. The nest on the right contains eggs which must be on the point of hatching, whilst that on the left holds a family-two in number-of fully fledged young Rooks. These young Rooks are at the moment lying on the edge of the nest, apparently overcome by the heat; at least they are in the direct rays of a summer sun, and with half-open beaks are panting heavily. 
A terrific commotion, a flapping of wings, a cacophony of caws overhead, tells one that the Rooks are returning. What an uproar! They are certainly returning much more readily than we had dared to expect. In fact our companion has not yet disappeared under the Marsh Gate cherry-trees. And in less than five minutes, we see the Rook from the right-hand nest swing up into a branch not more than fifteen feet away, and stand there with lowered head and shining eye, satisfying herself that all is well before going on to her eggs. Then in a most amusing manner she sidles along the branch, yet nearer to us, towards her nest.

The nest is but twelve feet from the observation post so that as we watch her we can see every gleaming feather. What a mistaken idea it is to suppose that the Rook is 'black'; for as they catch the light her feathers reflect the most glorious greens and purples. And in what splendid condition her plumage is! As she steps on to her nest, and prepares by 'puffing out' her breast feathers, to cover the eggs, we cannot help comparing her with the battered travesties of her kind, that we sometimes see in cages.

As she lowers herself on to the eggs, we notice that her breast feathers are 'puffed out' to such an extent that they are almost horizontal.

The ability to raise the feathers in this way so exposes the bare patch of skin on a sitting bird's breast-which is known as the 'sitting patch'-as to allow the eggs to come in direct contact with her naked skin; the feathers, of course, closing around the eggs when the bird is in position.

As our Rook turns her head this way and that, the glossy feathers of her neck would seem almost to have been dipped in oil, so brightly do they shine in the sunlight. Presently, with her beak over her back, she commences to preen her flight feathers, and the little 'snap' of her beak as it reaches the end of the feather is quite audible in the observation post.

Rooks, in spite of their evil reputation, are exceedingly careful of their plumage and of the cleanliness of the nest. They spend hours preening and shaking their feathers, and are most watchful, when the young are hatched, that no foul matter is allowed to remain in the nest.

Anything of the kind is immediately picked up in the extreme tip of the beak, carried on to the surrounding branches and dropped overboard.

An excited 'car-r-ing' from the nest on the left announces the fact that the two young ones are about to be fed. As we turn to watch them, we see one of the Rooks advancing along a branch towards them with the food pouch stuffed with food. Reaching up on their shaky limbs, the young Rooks vie with one another for the first share, although little seems gained by hurry, for, before distributing the food, the Rook, with the help of her tongue, transfers some of the food to the tip of the beak, when it is placed down the throat of the young one.

Before the second young one receives a share he, too, has to wait until the 
process of transferring food from pouch to beak has once more been accomplished.

Having delivered her gifts, the Rook seems inclined to brood her young, and tries unsuccessfully to do so. They are really too large, however, and so she has to content herself by lying on the nest beside them-quite content, it would seem, to have them close by.

Some twenty minutes later the male Rook-if one can determine the sex of a Rook by the brilliance of the plumage-flutters into the branches and on to the side of the nest. Judging by the actions of the female one would think that she was suffering from the final pangs of starvation.

With quivering wings and uplifted open beak she cowers before her mate, begging him, it would seem, to give her food.

Quite unconcernedly the male transfers a little food into his beak, and presses it affectionately down her throat; then, ignoring her further entreaties, he turns his attention to the young ones, who although they were fed but twenty minutes before, seem as hungry as ever. Having fulfilled his mission he once more turns seawards and sails out over the marshes.

Hardly has he gone than the sitting Rook on the right vociferously welcomes her husband, and standing on her nest with wings aflutter, she too receives a donation of food.

As the day wears on, the two young Rooks on the left become increasingly restless. First one and then the other indulges in a bout of wing-flapping, at the same time jumping into the air as though to test the weight-carrying capacity of his wings. At any moment they may risk a trial flight to one of the adjacent branches; an idea in which their parents seem to be encouraging them, for when they return with food, they hesitate for some time before coming to the nest, as though luring the young ones into the branches.

And at last one of the young Rooks flutters into a branch a few feet from the nest; where, at his next visit, the parent liberally feeds him.

Then another step is essayed, and by short stages he soon reaches the tiptop twig of the home tree.

It is from just such a point of vantage as this that the first trial flights are made. The young Rooks love to climb upwards, and when they reach the highest point, they usually attempt a flight to-for instance-the top of the adjoining tree.

Should a young rook on such a trip be carried out of its course by a too boisterous wind, one or other of its parents will generally be close at hand to fly to its side, and with caws of encouragement to cheer it in its trouble.

So now there is only one young Rook remaining in the left-hand nest; although it is only a question of minutes before he too takes the fateful plunge. And at last he takes it, only unfortunately he seems to lose his head in the 


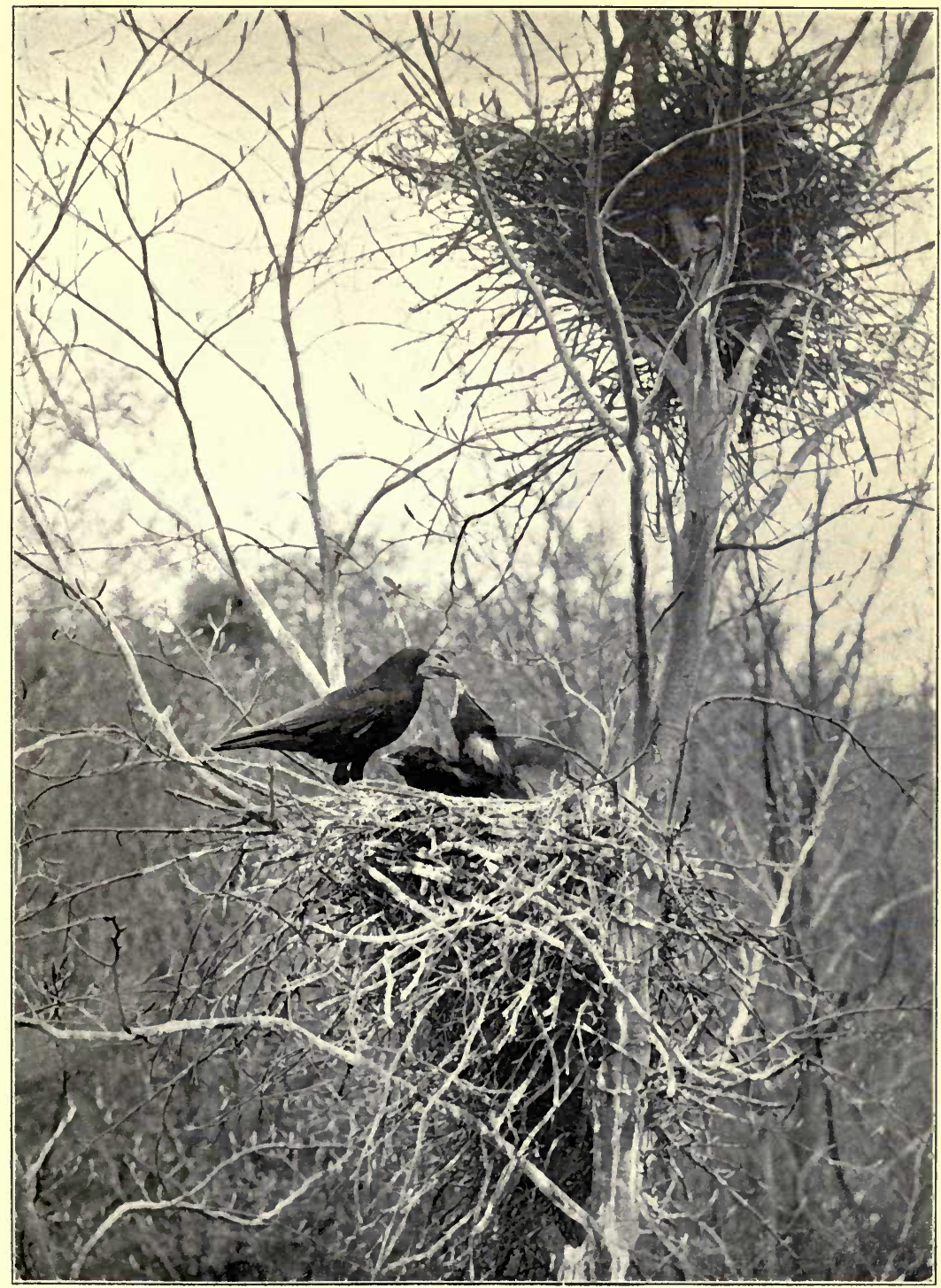

THE ROOK WITH HFR CLAMIOURING FAMILY 

excitement of the effort, and tries vainly to land on the back of the sitting female in the next nest !

This behaviour is naturally much resented, and the young Rook soon finds himself pushed overboard, where, hanging almost upside down, but clinging on desperately with his extraordinarily strong feet and sharp talons, he finds himself in a poor strategic position, and the target for a series of sharp jabs from the old female's beak !

At length thoroughly exhausted, and no doubt smarting from his injuries, the young Rook collapses and is only saved from a premature descent to earth by a branch that happily chances to spread just below him.

He soon recovers his composure, however, and is presently perched almost as high as his brother; where, amongst a company of some half-dozen other young Rooks, and two or three old ones, he seems at least temporarily satisfied.

It is whilst the old and young Rooks are thus sitting in groups that one notices particularly the strange characteristic which enables one to differentiate between them. Whereas the immature Rook has at the base of the beak a black feathery moustache-like growth which, as it were, lies along the upper mandible, and is very similar to the ' moustache' a magpie or crow possesses, the mature bird has the base of the bill surrounded by bare, greyish-coloured skin; by which, as may be seen from the illustrations, it may readily be distinguished from the Carrion Crow.

Our period of observation at an end, and the return of our companion expected at any moment, we will close this chapter by reminding the reader that during the hours which we have spent in the observation post, some rather trying moments have been experienced.

Cramp and mosquitoes are the two most common troubles - and one wonders what mosquitoes are doing at such a height. Then of course the seat is none too comfortable, and shoddy bags do not make the pleasantest of summer-houses.

However, there are many redeeming features, and among them the fact that, first of all, the Rooks have behaved exceedingly well, and secondly that there was never any need to remain absolutely quiet, for the Rooks have made sufficient continuous noise to drown any sound that the observer might accidentally produce. 


\section{CHAPTER II}

\section{The Buzzards of the Doone Country}

W

ITH the exception of the Golden Eagle, the Buzzard has perhaps the most impressive appearance of all our wild birds. His great dark-tipped wings with their widely separated primaries stamp him at once as a bird of the highest altitudes; whilst his flat forehead, curved bluish-black beak, and fierce deep-set eyes suggest a creature of deadly intent and immovable purpose.

Soaring high in the air above the wild undulating moorlands, he is so conspicuous as to attract and hold the attention of all who take pleasure in so unusual a sight.

With such majestic ease does he wheel aloft, mounting skywards without the least apparent effort on outstretched motionless wings, that one might well conclude that he must surely be classed among such outstanding fliers as the Hobby and the Peregrine.

Yet, in spite of his formidable appearance and graceful aerial evolutions, the Buzzard is not by any means a powerful flier, and, moreover, he is possessed of a comparatively poor spirit : in fact, when one considers the type of food upon which he usually preys, one is inclined to marvel at the methods of certain game-preserve owners who have allowed Buzzards to be obliterated on every possible occasion.

Perhaps the Buzzard, like the Kestrel and the Little Owl, has been accused of taking too great a toll of the game-birds; but those of us who are acquainted with the flight of-for instance-a covey of partridges before a good game hawk, and have noted the agility with which they are able to take advantage of cover, will realize the absurdity of the suggestion.

The Buzzard, who either grabs his quarry at the first dash, or swings by it like an express train whose brakes have failed to act, would have a very poor chance of taking a full-grown partridge, and we may be sure that, in the case of cheepers, or newly-hatched young, the warning cry of the old bird, which would be uttered the instant the form of the Buzzard loomed into view, would cause the whole family to vanish into hiding as though by magic. 
Still, the fact remains that the Buzzard is 'obtained' annually in such numbers as would lead us to suppose that-were it not for the last few inaccessible or protected strongholds, he would, like the Kite and the Osprey, be on the verge of extinction.

Strangely enough, this imposing bird, towards whose soaring form many admiring eyes will be turned, is of a somewhat slothful nature, for he feeds largely upon such undignified food as lizards, mice and earthworms; and may be trapped on dead bait more easily than any other of our birds of prey.

A rabbit's paunch effectively arranged will generally prove sufficiently attractive to appeal to the Buzzard's ' penchant' for this delicacy.

Such a large bird cannot be expected, of course, to rear its family of voracious young upon such meagre food as beetles and earthworms, and must of necessity resort to killing creatures of more substantial proportions; just as the modest Kestrel, when it has a family to rear, will tackle and secure such formidable opponents as blackbirds and starlings.

One is prompted-when considering the nature of the Buzzard's foodto wonder why the bird should have been so adversely criticized by famous ornithologists.

He has been called ' cowardly,' sluggish, degenerate, and so forth, but after all, none of us are perfect, and one cannot expect a bird which has not been equipped by Nature with the powers of flight of a Hobby, to provide such a dashing demonstration of wing power as that little Falcon unconsciously displays. He cannot be more than-by comparison-a poor flier. Neither can we presume that a bird not endowed by Nature with the Goshawk's lust for killing, should be anything but-by comparison-a lethargic chickenhearted creature. One does not hear of Owls being recorded as 'dastardly' or 'stupid.'

And in the writer's opinion the Buzzard is not in any sense cowardly or sluggish. He certainly would seem to feed mainly upon young rabbitsprobably because they are a most satisfactory quarry from every point of view. They are to be found in countless numbers; they are comparatively easily picked up-during their preoccupation of feeding, and, lastly, their flesh seems admirably to suit the requirements of the young Buzzards.

But, if put to the test, the Buzzard can, and will, hold an energetic fullgrown rabbit; and does so with a determination that cannot be shaken by the rabbit's most violent struggles to free itself.

Surely the most critical, the most superior, of us humans cannot call him sluggish as, exerting every ounce of strength, he makes in a bee-line for the selected quarry. Almost stooping as he comes down from his 'pitch,' he swings along at considerable speed, and binds to his victim with a grip from which there is no hope of escape. If he chances to seize the prey by 


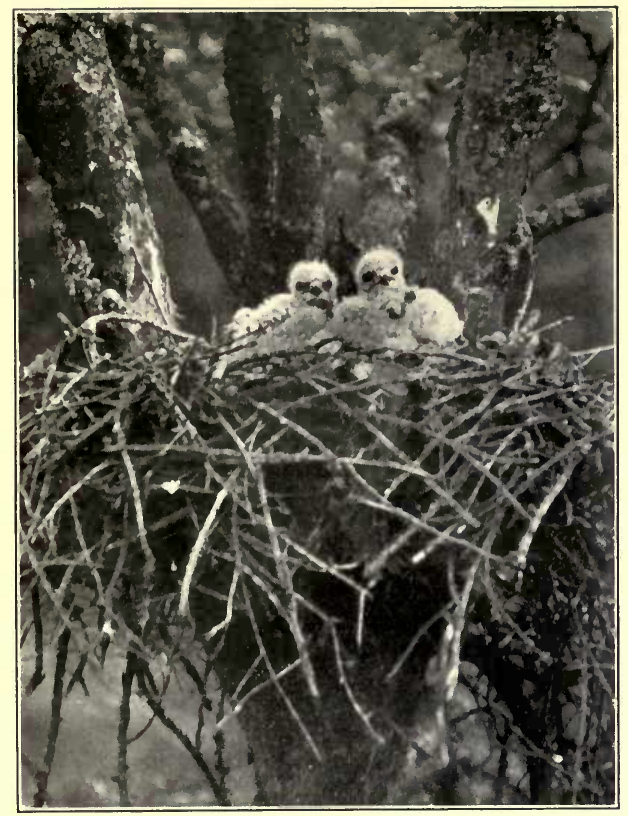

THE YOUNG

IBUZZARDS

THE HUZZARD SEIZINC; IIIS PREY

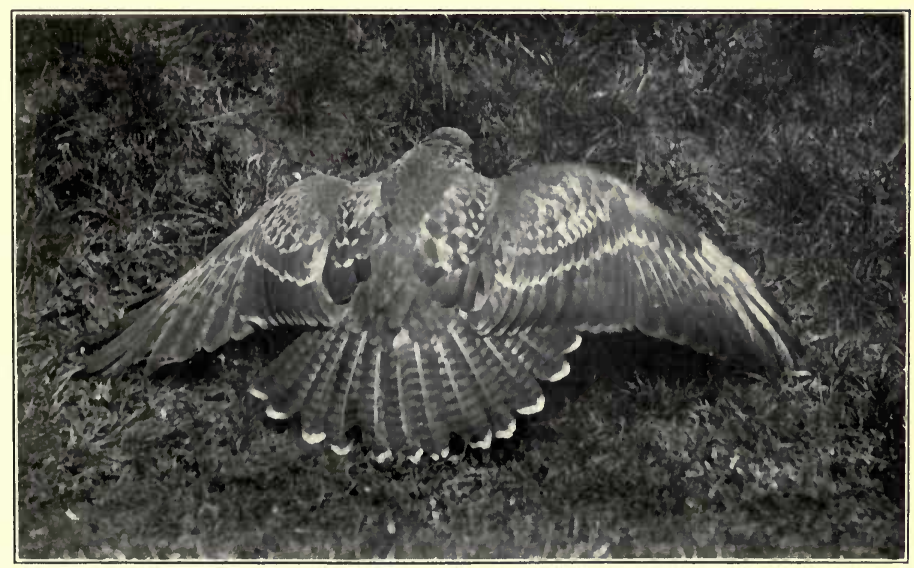


some awkward portion, such as a hind leg, he endeavours with his disengaged foot to grasp its head, and if he succeeds, any struggles on the part of the victim are hopeless.

One might be justified in terming a Buzzard 'dastardly,' if it should chance to grip one's naked hand in its vice-like clutch.

Buzzards feed upon moles to quite a considerable extent, and easily pick up these little animals in the dry summer weather, but the writer's experiences would point to the fact that they prefer rabbit to any other food. It is a quaint fact that the Buzzard will attack such modest opponents as lizards and Moles, with as much fierceness and impetuosity as he does the strongest rabbits ; although in the case of the smaller quarry he, in his ardour, usually grasps handfuls of grass, among which the victim is literally crushed to death!

So the Buzzard might-from our point of view-be described as 'simple,' and perhaps also unnecessarily provident, when it is told that in spite of his comparatively clumsy flight, he contrives to carry to the nest food far in excess of the requirements of his family.

The Buzzard's special forte-where flying is concerned-is soaring-and he soars more beautifully than any other British bird. The question how a bird can, without any appreciable effort, travel in such circles and gradually rise to such vast heights has often been raised.

It would seem, to the writer, that the reason that the Buzzard is able to do this more successfully than the other hawks is that he has a relatively small body and unusual spread of wing - that he takes advantage of the least breeze, and mounts in the air very much after the manner of a kite. He seems to allow himself, with wings full spread, to drift on the breeze for a distance-then with the impetus so gained, he describes a large curve until he is facing the wind, in which position he is carried slightly upwards. As he loses his momentum, he describes the other half of his circle, and travelling with the wind for a while, again gathers sufficient impetus for another turn against it.

Sparrow-Hawks and Kestrels also soar, but not nearly to the same extent, and generally flap their wings when travelling on the downward side of the circle, in order to gain the required amount of impetus to carry them upwind.

In any case, a soaring Buzzard is a most impressive sight, and may easily be mistaken -in a possible district-for a Golden Eagle.

Buzzards commence to build in about the beginning of May, often on the ledge of a cliff overhanging the sea, but at times among the upper branches of a deciduous tree, perhaps most frequently in an ash. They return annually to the same breeding-areas, like the majority of our hawks, and in consequence, if the enthusiast spends much of his time in a district which they inhabit, he will probably have little difficulty in discovering a nest, if he should desire to do so, for the Buzzard cannot be considered a rare bird. 
When, however, the writer visited the part of the country we are now referring to, he experienced considerable difficulty in finding a Buzzard's nest.

Of course the shapes of Buzzards soaring high in the evening air, sometimes three or four together, were very encouraging and inspiring; but after having spent several days of fruitless endeavour, the only way of solving the problem seemed to be to ask the natives if they had ever come across a Buzzard's nest anywhere.

The replies were very interesting, but not altogether what was wanted. For he learnt that the Buzzards' nests were exceedingly difficult to find ; that they were usually constructed in some precipitous cliff overhanging the sea, that the birds laid as many as six eggs, and fed largely on lambs.

A little more persuasion, and maybe the informants might have been encouraged to declare that they sometimes even carried off babies !

The writer had, ' before the war,' been lowered on a rope to some Buzzards' nests in the cliffs of our south-western shores-and now seriously contemplated making a trip to the sea coast. Being, however, particularly interested in the tree-nesting birds of these Islands, he decided to continue the search among the wooded country on the edge of the moors.

For a time the hunt was continued without any indication of a nestexcept that one evening a Buzzard was seen flying low over a beech hedge towards some distant trees, the consequent search revealing only a Kestrel's nest with eggs, and a magpie's nest containing a solitary young Tawny Owl.

The next day, however, a Buzzard was seen at really close quarters. Fifty yards ahead of us as we approached across the moor, he rose from the side of a mountain stream where apparently he had been indulging in a bath ; at any rate, he settled on a rock some 200 yards away, and by the aid of the glasses we watched him preening himself and arranging his feathers with the utmost solicitude.

The Buzzard, in spite of his evil reputation, is much addicted to a bath; probably even more so than many of his more distinguished relatives.

The direction of his flight when he eventually did take wing was no guide to the location of the nest, as he straightway soared to an immense height, and at length disappeared from view.

The following day, whilst sitting on a bank overlooking a deep, partially wooded valley, and discussing the possibility of a visit to the seashore, the writer-or his companion-chanced to spy in a distant tree, a dark lump that looked from such a distance-probably a good half-mile-like a large nest. Closer investigation, with the aid of glasses, showed that it certainly was a nest, and by all appearances a new nest.

Hoping devoutly that it wouldn't turn out to be a crow's, and not daring to suggest even to one another, that it looked as though it ought to be a Buzzard's, we collected our belongings and set out towards it. 
On the way, one of us remarked in an off-hand manner that it looked exactly like the pictures that one has seen of a Kite's nest, and built high up in the fork of one of a clump of tall ash trees on a steep hill-side, surrounded by the wild beauty of the Doone country, the eyrie, now only about 200 yards away, really looked extraordinarily impressive.

And a moment later we saw a huge Buzzard-almost golden-brown on the upper parts it seemed-rise from the nest, and spreading her great wings, swing out and away over the valley.

The excitement of the enthusiast at such a moment cannot be describedpossibly it borders on the ridiculous! In any case the tree was reached in an incredibly short time, and the discovery soon made that it would be no easy matter to climb it.

From the top of the hill we found that a good view of the nest could be obtained, and with the help of the glasses we could see that there were some young Buzzards on it-at least, an indistinct white mass suggested young Buzzards in down.

This discovery led to renewed efforts to negotiate the tree, and at length, with the help of a long larch pole, the thing was accomplished-though not without a good deal of exertion, for to 'swarm ' up thirty-five feet of ash stem to the lowest branch is not an easy business, particularly when the trunk is too large to allow the climber to clinch his fingers.

All this time the female Buzzard with motionless wings, on which we could distinctly see the alternate black and white bars, described great circles above the tree, at the same time uttering a loud intermittent mewing cry, which indeed she did whenever the nesting-tree was approached too closely.

There is a certain uncanny charm about this mewing of the Buzzardsa strange wildness that is, without doubt, enhanced by the grandeur of the surroundings.

The nest was found to contain three young ones (and this is the usual number), two females and one male, which, judging by the fact that their feathers were just coming through the down, must have been about two weeks old.

One can usually determine the sex of young hawks in the nest by the varying sizes at the same age, the females being larger than the males, though the difference in the case of Buzzards is not so marked as with most of the other hawks.

On the sides of the nest were two large piles of young rabbits-a total of thirty-five-far more of course than the young Buzzards could ever hope to consume. Those on the top of the pile were quite fresh, evidently having been secured the same day: though the less recent additions at the bottom of the pile had been in position so long that they were literally a mass of maggots. All of these young rabbits had been roughly plucked and practically all had had their intestines removed. 
It is common knowledge that the males of our smaller hawks carefully pluck the bodies of any birds they may secure before carrying them to the nest; but it may not be generally known that the Buzzard, obeying the same instinct, prepares his rabbit food in the same way.

Whilst I was examining these trophies on the nest, the male Buzzard arrived with yet another young rabbit hanging from his talons! On seeing me, however, he turned aside, dropped the rabbit and later joined his mate as she circled and mewed in the sky.

The nest turned out to be rather unsatisfactory from the photographic point of view, the only possible tree in which the camera could be fixed being too far away. However, there was nothing for it but to make the best of things, and an 'imitation camera,' consisting of a bundle of ferns tied up with string-was accordingly placed in position in the neighbouring tree at a point overlooking the nest.

And having completed these preliminaries, we quietly withdrew.

In two days' time, another visit was paid to the Buzzards' tree; this time with the idea of constructing a hiding-place into which a string from the camera could be run, and which might be pulled-in order to release the shutter -at the psychological moment.

As we drew near to the trees one of the Buzzards-the female, in all probability-flew up from the ground under the nest, and dropped a young rabbit which was quite warm. As we worked on the hiding-place we heard both of them mewing, and saw them soaring above us-and doubtless watching every movement! - at an immense height.

That same evening another visit was paid to the Buzzards, and this time, by creeping along behind a beech hedge we got quite close to the trees without ourselves being seen.

The female was on the nest, and through the glasses we could see that she was lying on the side of the nest by the young ones, very much in the same way as the female Rook did when the young were too large for her to brood.

Presently, from the direction of the moors, we saw the male coming in with another ill-fated young rabbit-about half-grown-hanging from his talons. Somehow it reminded me of an old print which impressed me very deeply years ago, and which portrayed an owl flying along with a live stoat hanging by the teeth from its throat.

The male Buzzard meanwhile continued towards his home tree, and when he drew near, planed down to within some ten feet of the ground, and then on outstretched wings, suddenly swung upwards and on to his nest. On his arrival the female stood up, but seemed in no hurry to relieve him of his catch; nor did she object to his tearing some small pieces from the rabbit which he had brought, and delivering them to one of the not too eager young ones.

Anxious no doubt that the larder should be plentifully stocked, the male 


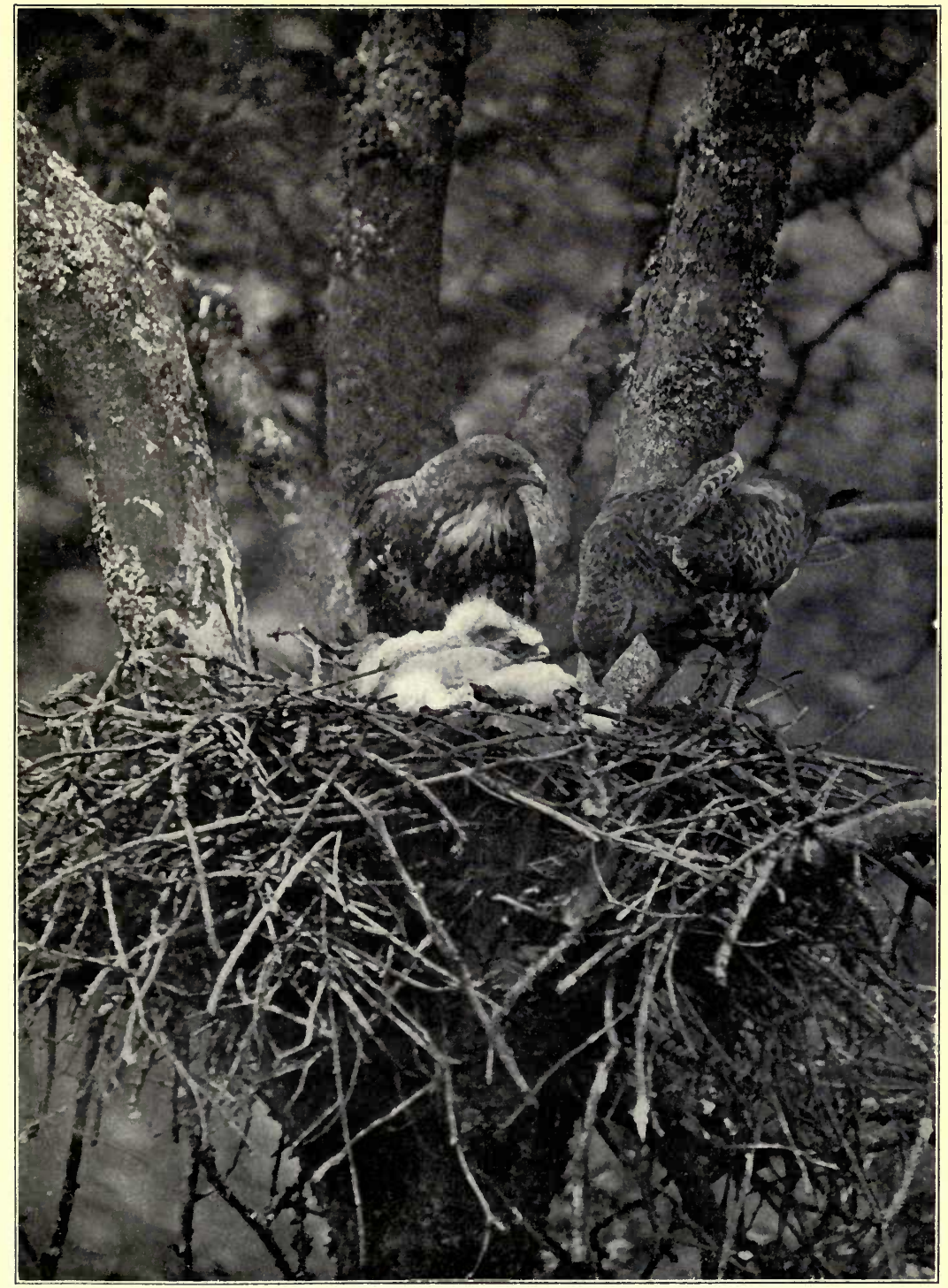

THE MALE BUZZARD DEPOSITS YET ANOTIER RABBIT ON THE NEST 
then swung out of the tree, and disappeared once again in the direction of the moors.

Two days later it was decided that photography should be attempted, and in due course the actual camera was substituted for the bunch of ferns, a string was run through a series of screw eyes to the foot of the camera tree, and thence to the operator's hiding-place, and the dark-slide withdrawn in readiness for an exposure.

Meanwhile both of the old Buzzards were soaring overhead, and, of course, watching all the arrangements.

This was a difficult piece of country in which to outwit the keen-eyed Buzzard, for since there was no cover he could see from his position on high all that was going on below, and incidentally any one who entered the hidingplace.

After a considerable wait, however, the female Buzzard returned to the nest, and distributed some portions of rabbit among the family. Then for a time she sat at the side of the nest, resting and preening her feathers. Presently she walked to the opposite side of the nest, picked up a small rabbit, and after some slight hesitation, flew off with it. In about fifteen minutes she returned without the rabbit, and continued to rest and preen as before.

About two hours later the male-bearing another small rabbit-joined her. On this occasion the young Buzzards did not seem to be in the least degree hungry - the first young hawks in the wild state I have ever seen that were not ready for food.

Before leaving that evening, I climbed up to the nest and purloined some half-dozen of the newly-gathered young rabbits. They are, in the fried state, excellent for breakfast.

I noticed, whilst at the nest, that the Buzzards had been decorating it with some fresh leafy twigs from one of the beech trees.

Whilst at the nest on our next visit, we remarked that the Buzzards were less timid than on previous occasions; they both soared at a much lower elevation, the female ultimately settling on a small beech tree growing from one of the beech hedges so common in the district.

This apparently insignificant incident led to a most interesting exhibition -which at least proved that the Buzzard, although a slow flier, is capable of performing some remarkable evolutions in the air.

It so happened that in the beech hedge was a Carrion Crow's nest, containing almost fully grown young ones-and the parent crows, noting the proximity of the great bird of prey, evidently decided that drastic action must be taken, for the Crow, like his cousin the Rook, heartily abhors the Buzzard and his tribe.

Soon both of the crows were in the air, circling and half-hovering over their enemy's head. Then one of them, with wings thrown back, would put 
in a dashing stoop, so accurately timed that the astonished Buzzard would duck his head to avoid that black form that whizzed by him like a shell from a field gun.

And hardly had he recovered from the shock than the other crow, turning over in the air, would follow with another well-timed shot, and again the Buzzard flinched involuntarily as the sable form flashed past.

By this time the first crow, who had really thrown up to a most creditable height, was in position for a second stoop, and with the advantage of a greater height to help his speed, the shot was considerably harder than the preceding one, so hard that, as he almost struck the Buzzard's head, he literally bounced again into the air.

Things seemed to be becoming altogether too hot for the demoralized Buzzard, who, since he was clinging to the beech branch, was quite unable to defend himself. So spreading his wings he set out, with slow dignified flight, to more restful quarters across the valley.

The crows, whose morale was much improved by this development, redoubled their efforts, and following up the retreating form, put in stoop after stoop, uttering as they did so the curious harsh chattering, almost shrill ' caws,' that a rook makes when shifting from a Falcon.

Our dignified friend was now becoming thoroughly roused, and all at once, just as one of the crows swept towards him, he suddenly turned upside down in the air, and struck like lightning with his talons at his adversary; only missing him, it seemed, by the fraction of an inch. This ruse had the effect of distinctly damping the ardour of the crows, for they kept at a more respectful distance, and only stooped in a half-hearted way, not wishing to come to grips with the Buzzard.

At length they gave up the chase, and retired in the direction of their home.

But our friend was not allowed to travel far in peace, for now he was traversing an area occupied by another pair of crows; and these carried on the work of the first. The unfortunate Buzzard again experienced the annoyance of having first one, and then the other crow attacking him from the rear, and again tried, by turning upside down and snatching with his talons, to cut down one of his opponents, but again without success.

We noticed that whenever one of our Buzzards flew at all close to the ground, a fierce onslaught would be made on him by the pair of crows who had appropriated the area over which he was passing.

Perhaps this fact may have prompted the male Buzzard-who like the males of other hawks seem to do most of the hunting-to return from his foraging expeditions at a considerable height.

On one occasion whilst watching the young Buzzards, I saw a Magpie fly into the tree, and take from a branch below the nest a piece of rabbit-or 
rabbit skin-which had fallen overboard; I have also seen magpies thus searching for scraps of food under a Heron's nest.

Later visits to the nest showed that the already overflowing larder had been still further replenished with supplies of young rabbits, together with a few castings composed entirely of rabbit's fur; whilst the ground below was dotted with little patches of rabbit fur, showing where the Buzzards had plucked their victims.

So it would seem that the Buzzard, incapable of taking an assortment of food for his family, makes up for the shortcoming by procuring an abundant supply of the one item whose capture causes him the least inconvenience.

A characteristic which it is hoped will not be regarded too seriously. 



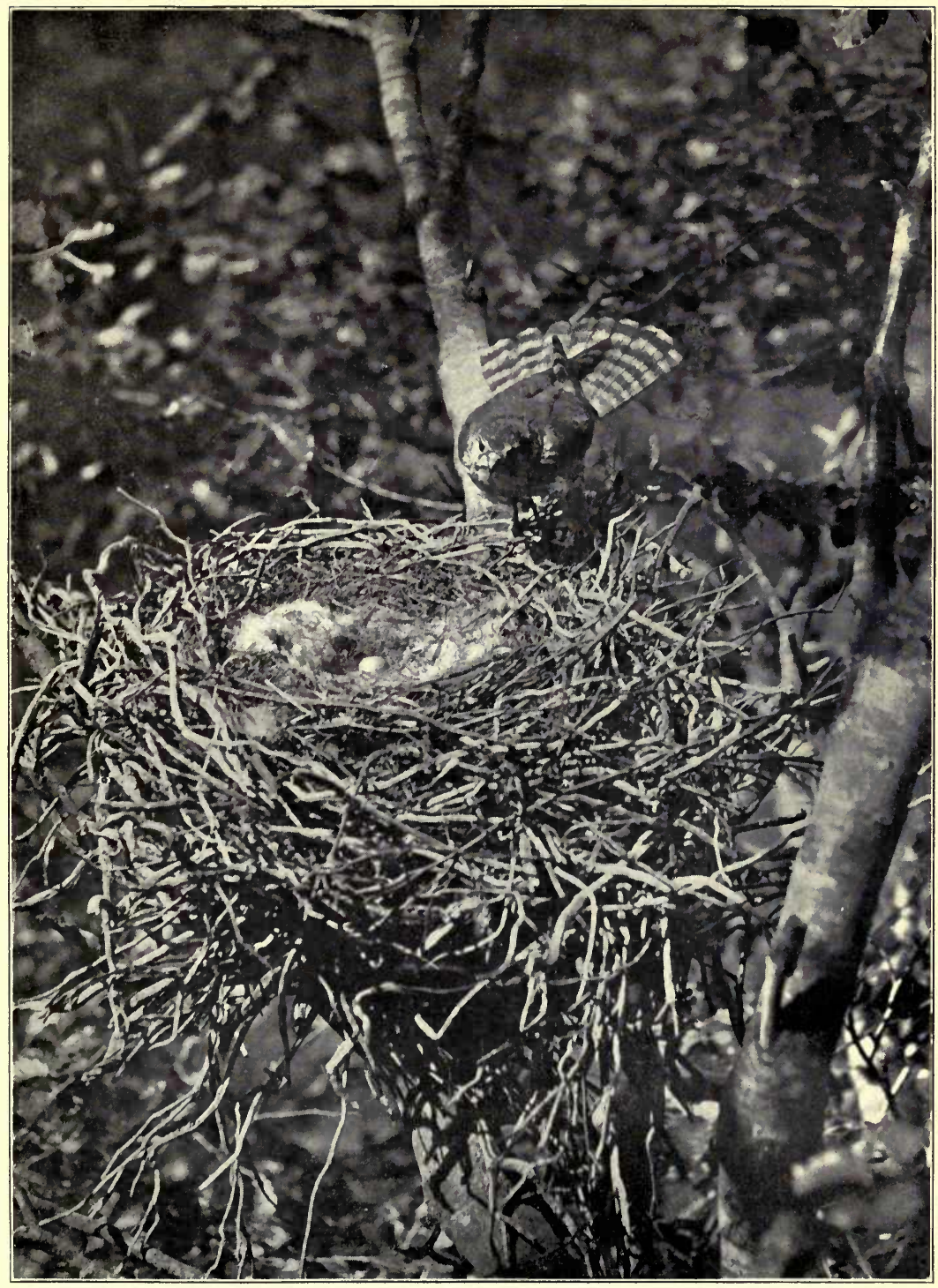

THE MERLIN WIIH TAIL UUTSPREAD 


\section{CHAPTER III}

\section{The Lady's Hawk}

T is a strange thing that our individual affection for birds should generally somehow centre on one particular variety; that each one among us, 1 for some reason or other, should have a leaning towards some special kind of bird.

There are some who consider a robin the most attractive of our feathered friends, others who prefer a bird of paradise, or a parrot.

For my own part, I must admit that I have a distinct penchant for the hawk tribe. It is difficult to say exactly why, unless it is because they are such keen, sporting creatures.

There are of course many who regard a hawk as being typical of cruelty -although in reality the hawk is not more cruel than the majority of other birds-only it happens to be the nature of a hawk to live upon other creatures, irrespective of whether or not those creatures chance to afford us pleasure.

The thrush is not criticized for banging the snail against a stone, nor the owl for killing rats and mice-although such creatures doubtless have very pronounced views on the subject. But then snails, and rats and mice, do not generally appeal to us.

The fact that hawks are so cruel as to eat birds, does not prevent us from accepting a brace of partridges when they are forthcoming - or a leg of mutton for that matter!

It is the nature of the hawk to kill and feed upon the flesh of other birds, mammals, or insects-it is its only means of subsistence; and in order to enable it to obtain such food it is endowed by Providence with extraordinary powers of flight. The methods of the different kinds of hawks in pursuing and catching their prey, vary very considerably, and the writer will attempt to describe in the course of this volume the styles of flight of the four small British hawks, all of which he has discovered nesting in trees.

These four varieties are :-

The Merlin - the Hobby-the Kestrel-and the Sparrow-Hawk; and of them all, the little Merlin, when in pursuit of its prey, is without doubt by far the most persistent. 
In that far-off age when Falconry was the sport of Kings, the Merlin was, on account of its docile disposition and charming ways generally assigned to a lady, and in fact was known as the 'Lady's Hawk.'

The Merlin of to-day, even in the wild state, would seem to be upholding this enviable reputation, and the writer has never yet been so fortunate as to have had dealings with any bird so good-natured or so confiding as the little hawk appearing in the accompanying illustrations. It is indeed a delightful experience-and also a very rare one-to meet a creature of the wild, which almost from the first seems to recognize one as a friend.

The usual nesting-places of the Merlin are confined to the open moors of the North of England and Scotland, where the little hawk deposits her eggs in some slight depression of the ground amongst the heather. So it came as a double surprise when hunting one day for a Buzzard's eyrie in the south-western corner of England, as described in the previous chapter, we not only came upon a Merlin's nest-but what was very much more remarkable-a Merlin's nest in a tree!

In the heart of such country, trees are, of course, very few and far between, and it is difficult to say why the hawks should have selected such a lofty home, particularly as acres of heather stretched in almost every direction.

It was an uncanny rushing noise high in the air above us, very much like the slithering whine of an approaching ' heavy,' that was really responsible for our first sight of the merlin; for glancing upwards to discover the cause of it, we saw a Peregrine rushing earthwards in a headlong stoop. She obviously meant business, but of a sudden, catching sight of us, she turned from her purpose, and like an arrow, shot up again into the blue.

Whilst watching the carrion crows mobbing the Buzzard we had really been rather deeply impressed by their manner of stooping and of throwing up - but compared with the style of this expert, theirs was indeed a clumsy performance.

For a while we gazed at her diminishing form in admiration and wonderment. What on earth can she have been stooping at? And then, down in the valley below where a mountain stream tinkled past a solitary clump of beech trees, we saw what we had not seen before-a female Merlin in hot pursuit of a Carrion Crow.

A Merlin! Here indeed was an unexpected, and, at the same time, a most welcome sight. And judging by the persistence of her attacks upon her sable enemy, one would imagine that she had a nest somewhere close at hand. Soon the two of them were going hard at it over the moor, the crow avoiding the Merlin's stoops by cleverly shifting at the psychological moment. The speed with which the little hawk overhauled the crow was almost incredible, but since she put in a stoop at every few yards, and threw up to the same height as that from which she started, she naturally had the 
advantage of the impetus gained by the 'drop,' and caught up the crow with extraordinary ease.

It is remarkable with what ferocity birds will drive away from the vicinity of their nest any creature which might possibly have evil designs on their eggs or young.

Thus the Rook harries the Falcon; the Thrush the Owl; and the Merlin the Crow.

In a short time the pair of them were almost out of sight ; the one croaking an angry or terrified remonstrance, the other pressing the attack with undiminished energy.

Of a sudden the Merlin gave up the chase, which had really proved quite exciting, and turning, planed back in our direction.

Down among the heather we dropped, and had some difficulty in catching sight of the hawk again, her bluish-grey plumage harmonized so well with the moorland background. However, she was still making straight towards us in a very definite kind of way, and for the first time I dared to believe that she must have a nest somewhere close at hand.

Nearer she came, flying low and straight, and for a while the thought that she might pass overhead and see us crouching there occurred to us; but to our amazement she changed her direction, and swung upwards into the top of one of the beech trees.

For a time we hesitated about venturing into the open, but since nothing further occurred, we decided to go forth and investigate. Up then we got, and with eyes fixed on the spot where we had seen the Merlin settle, we advanced towards the beeches.

On our arrival under the trees, we almost immediately caught sight of a crow's nest, and half expected to see the Merlin go off. Personally I experienced a thrill of disappointment when, on climbing up to it, I found that it contained a single crow's egg.

And still there was no sign of the Merlin. We began to wonder if she had gone off behind the trees as we approached, and was perhaps at the moment sitting on her nest amongst the heather. However, the accidental snapping of a dead branch had the effect of proving that our fears were unfounded: for it was greeted by the screaming of a hawk in one of the trees at the far side of the clump. Soon we had spied a second crow's nest, built almost at the extreme top of one of the beeches; and peering at us over its edge, the head of the little Falcon!

But in any case, none of the trees were really tall, the merlin's nest being not more than thirty-five feet from the ground. And since the tree was quite a comfortable one to negotiate, no time was lost in climbing up to inspect the situation, the Merlin going off when the actual ascent was begun. The nest, a typical crow's, was strongly constructed and lined with 
quantities of sheep's wool, and contained three of the Merlin's eggs ; which in coloration are so similar to Kestrels' and Hobbys' that unless one had seen the bird it would not be possible to say which of the three they belonged to.

The nest was not particularly well situated from a photographic point of view. Still, a 'dummy' camera, similar to that utilized in the case of the Buzzard-only this time it consisted of an old tin and some beech leaves -was fixed in position as silently and rapidly as possible, and with so much success that even whilst the writer, who had climbed the tree, was on his way to earth, the little Merlin returned to the nest, and settled down upon her charges. The confidence of the bird was indeed most delightful.

During the next few days we paid the Merlin almost daily visits, and found that she actually grew tamer as time went on.

Sometimes when I climbed up to arrange the camera, she would not leave her nest until my head was on a level with her ; and when I had finished she would invariably be back upon her eggs before I had reached the ground.

We noticed that if an unusual time were taken in fixing the camera, she would-having flown about the tops of the trees for a while-go across the moor to a large solitary stone, shaped rather like a tombstone, some 400 or 500 yards away, and take perch there until she thought the time had come when she might return and see if the coast was clear.

It was never really necessary to make a hiding-place from which to release the shutter; all that one had to do was to sit quietly under the trees, and pull the string at the desired moment. She never took the least notice of the 'flop' of the shutter, so that as a rule we did not climb up at once, but rested until we thought that, without risk of hurting her feelings, we might venture to change the dark slide.

At length the idea oceurred to us of making a hiding-place by the stone on which she usually sat, for she would be pretty certain, if disturbed, to take perch there.

So one morning we set out with pick and shovel to construct a hide some twenty-five yards from the Merlin's stone; and having dug through the peaty surface, we eventually made a sort of rustic dugout, roofed over with stems of heather and grasses, inside of which the camera was duly installed.

The ruse was successful, for when put off the nest by one of us, the little Merlin, having flown round the trees screaming some half-dozen times, made straight for her stone, and sat there whilst some exposures were made.

On one occasion, whilst flying thus round the trees, she was joined by her mate, who, screaming in a shriller tone, and bearing a small bird in his talons, seemed much upset on her behalf. As they swung this way and that, one noticed at once the difference in size between them; for the male Merlin (or Jack), is considerably smaller than the female.

This rule applies to all of the hawks, but is more marked in the case of 


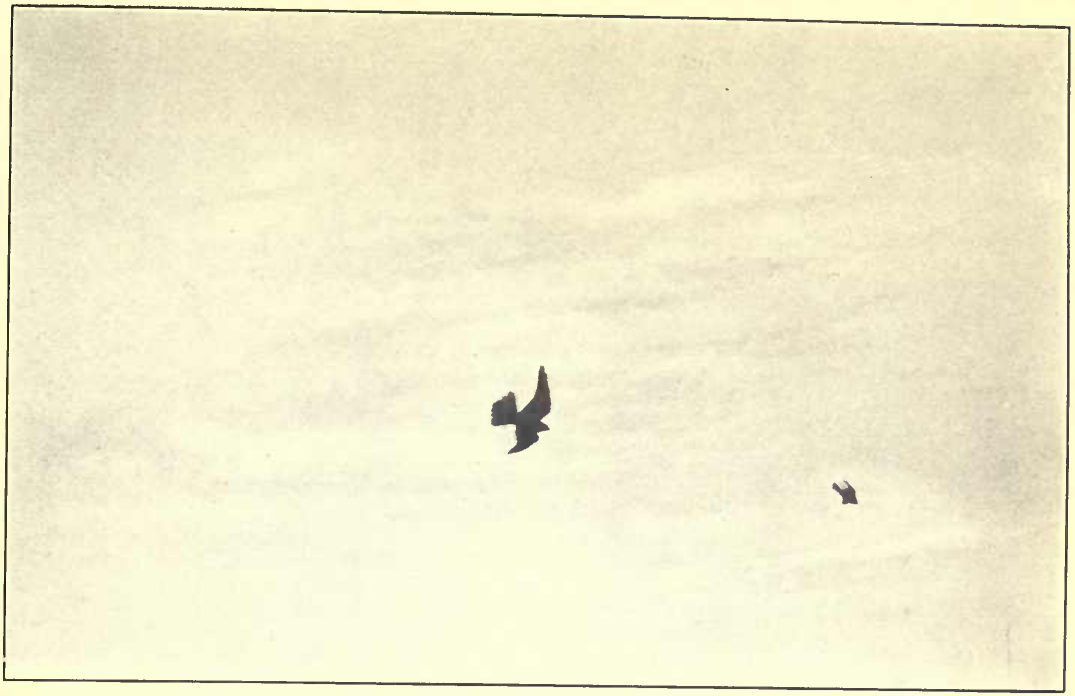

THE NERLIN PURSUING HER QUARRY-

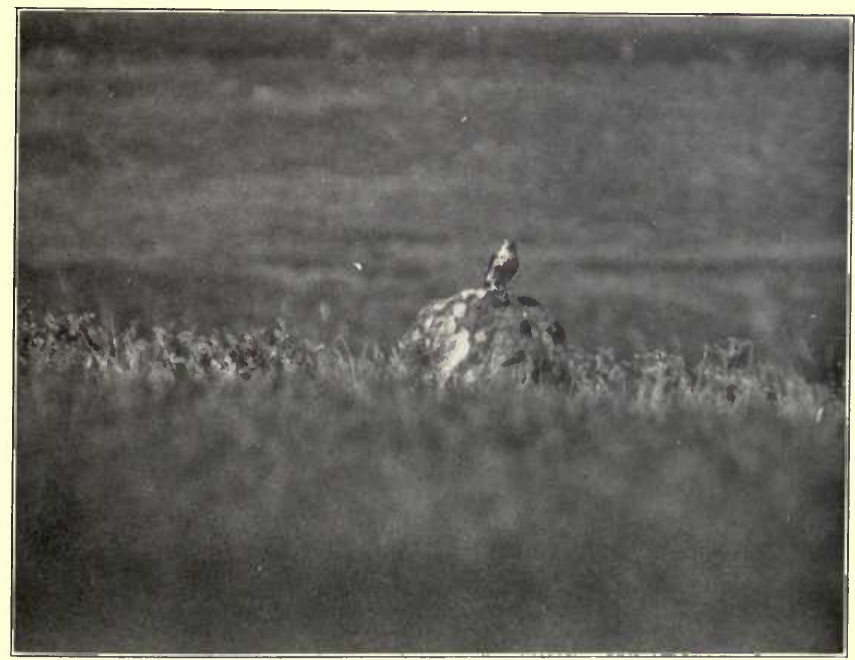

AND ON THE PLUCKING STUNE 
some species than in others. A male Sparrow-hawk, for instance, is an insignificant, peevish little fellow compared to his vastly heavier and more powerful wife. In the case of the Kestrel the difference is not nearly so marked, and unless one can distinguish the markings it is impossible to say at a distance if the bird is a male or a female.

On only one occasion did we get a really close view of the male, and that was whilst we were resting under the trees one extremely hot afternoon.

He appeared most unexpectedly, arriving without a sound except for the suspicion of a flick of wing as he settled. What an amazingly beautiful little thing he is! So small, so slender, so perfectly formed, he looks the acme of neatness and dexterity.

$\mathrm{He}$ is more brightly coloured than the female too; his back and tail are much bluer, whilst his throat and breast are of a brighter yellowish-red colour.

He had evidently called to see if things were in order, and soon left again, apparently with the idea of catching some food. In any case he again flew past the trees some twenty minutes later, and uttered his call-note.

Immediately the female left the nest, and crossing to a bank some fifty yards away, took from his talons a small bird which he had already plucked, and carried it away with her. When she returned after having partaken of her meal, she uttered the curious little 'chip-chip' noise, as Kestrels do when they have more food than they know what to do with.

The male Merlin invariably plucks, more or less carefully, any birds which he may catch for the female, and usually selects a convenient molehill, or small mound, on which to do the work comfortably. The particular Merlin that we are discussing here had a favourite plucking-place in the shape of a rock projecting from a bank at the side of a stream. It was interesting to examine the feathers around the rock as one could tell what birds the Merlin had been feeding on-and perhaps what birds it had not been feeding on.

Certainly there were no grouse or partridge feathers-although I cannot hope that this piece of information will influence those who are in the habit of shooting Merlins-neither were there any that had belonged to Plover, Ring Ouzel or Missel-Thrush.

In fact, the feathers littered thickly about the rock originated on two kinds of birds, and two kinds only-meadow pipits and larks-both of which species abound on the moors. There are in fact so many that one would not think it would be worth the Merlin's while to risk a trouncing from the mother grouse, by attacking her young ones.

It has been said that Merlins have been known to attack and kill plover -but the writer ventures to think that there must be some mistake about the assertion, unless the victims were handicapped in some way; for a mature healthy plover is as fine a flier as we can hope to see, and it is doubtful if there is any hawk that can catch one. 
Of course it is possible that the Merlin might appear suddenly whilst the plover were feeding, and bind to one of them before it had time to realize what was taking place; but such an occurrence must be extremely rare, and those who have watched the extraordinary ease with which plover can tumble and corkscrew and dive in the air, will realize what a hopeless task any hawk would have who should attempt to catch one of them.

Nevertheless the Merlin is an exceedingly fast flier, and is moreover so persistent that if she should start in pursuit of some quarry, she will stick to her task until one of three things happens: She may succeed in catching the victim : it may throw her off by diving into cover and remaining motionless, until, tired of vainly searching for it, she decides to pass on ; or the quarry may fairly beat the hawk in hard flying-and the last is not by any means an improbable finish to a long flight.

I have watched a wild Merlin trying to come to grips with a strong lark high in a cloudless summer sky, and have literally marvelled that either of them should have been able to stand the test so long-for such a flight involves some furiously hard work.

Each time that the Merlin put in a stoop, the Lark would-at the precise moment, when, with bated breath one unconsciously whispers, 'She's got him!' - suddenly flick aside, and the little hawk having again missed his mark would throw up, and turn again for another shot. Again the lightning rush, and again the lark is missed by 'the skin of his teeth.'

And so they go on, the one exerting every ounce of strength, and trying by every dexterous move to clutch the elusive quarry; the other, confident in the power of his wing, striving by timing his shifts to the barest fraction of a second to avoid the deadly stoops.

And so they disappeared from sight-both apparently as game as ever.

Since the Merlin was so popular among the Falconers of the Middle Ages, and since in fact the art of Falconry has never been actually a lost one, a few words regarding the little Falcon in the trained state may be of interest to the readers of these lines.

A trained Merlin is a most charming little pet, she is so easily reclaimed, and so happy to sit upon her owner's wrist, that it is small wonder the ladies of old held her in such high esteem. In addition to these virtues the Merlin, when trained, seems to be almost-if not quite-as keen for the chase as her wild relations.

It frequently happens, at least in wide open country, that if a trained Merlin should be flying some bird, a wild hawk will wait about until the 'dénouement' is about to occur, and then, benefiting by the Merlin's perseverance, will ' cut in' and snatch the reward from its rightful owner.

I have during the past season seen three different wild hawks thus cut in and attempt to seize the quarry-the first was a hen Sparrow-hawk, who 
literally dropped head first from the sky and tried unsuccessfully to force the prey away from the Merlin; the second was a modest Kestrel who likewise dropped from nowhere, and who so surprised the Merlin that she gave up, and the quarry continued on its way-doubtless much relieved!

And in the third case the intruder was a wild Merlin, who co-operated with the trained hawk in a most masterly fashion, timing his stoops so that the two of them never clashed ; so that always one or other of them was preparing for a new effort-until she ultimately succeeded in carrying off the prize.

A trained Merlin will often demonstrate the extraordinarily keen sight of these little hawks. As one is walking along with the hawk on the fist, she will quietly turn her head on one side and look steadily into the sky; on following the direction of her gaze one can almost invariably discern the form of some bird of prey, perhaps soaring at an immense height.

Two days ago I was crossing some stubble in the western part of Kent with a Merlin on my fist; three times did she thus turn her head and gaze upwards, and three times did I, wondering what she could see, attempt to satisfy myself on the point. But I could see nothing-although the day was cloudless and there was no mist. And yet a fourth time did my Merlin gaze aloft.

I then stopped and searched the sky as thoroughly as I might-for some time without success-but at last I made out, almost directly overhead, the form of what I think was a Buzzard or an Eagle, sailing on outstretched wings, which was at such a vast height that it would have been really impossible to identify it, I think, even had I had glasses.

It has been said that Merlins in the wild state are in the habit of killing, in addition to plover, pigeons and partridges. I, personally, have neverseen a Merlin kill either of these birds, but have not the least doubt that a Merlin would be perfectly capable of catching a pigeon, and of killing it in a very few seconds. But I do rather doubt whether a Merlin could kill a full-grown partridge. She could catch it, for as before remarked the Merlin is a most persistent hawk, and normally the partridge does not fly far-but I do not think that she could kill it. A healthy partridge has an upsetting knack of beating with its wings in a most rough, energetic manner, and I hardly think that a little Merlin - who is not nearly up to the weight of the partridge-would be 'man enough ' to hold on. A sparrow-hawk-yes-but a Merlin I am doubtful about.

Some time ago I had a trained Merlin which developed a sudden mania for chasing partridges-for some time without success, for the crafty birds would put in to any cover that might be available.

But at last, one day she 'bound to' a partridge amongst some potatoes; the rest of the covey, seeing their comrade in difficulties, rushing in to his rescue, and setting upon the poor hawk, soon had him free! 
On other occasions I have seen her catch a partridge, but never did I know her to kill one.

The way in which a Merlin kills a victim is at least most humane; for she seizes it by the neck in one foot, and a foot that has a grip of steel, and at once delivers the coup de grâce by giving a few sharp bites at the extreme base of the skull. It is all over in a couple of seconds.

The Merlin is a migratory bird, and does not always do well through the winter, so that in the beginning of October the Falconer will see that his Merlins are in first-rate condition-will take them into open country, and relieving them of their jesses, will-with a pang of regret-fly them from his fist for the last time. And now that they are to have their freedom once more, he can only hope and pray that they may steer clear of men, guns and traps, and that they may in due course rear their young in peace. 


\section{CHAPTER IV}

\section{In the Depths of a Fir Forest}

T USED to think that a fir forest was the most unproductive kind of place in which to hunt for birds' nests ; for it always seemed that the only 1 creatures which chose such gloomy surroundings for their homes were wood-pigeons and jays-and innumerable red squirrels.

I was always hoping that one day I might come across the nest of a Goshawk or Buzzard ; and well remember my joy at hearing the mewing of some sparrowhawks, which I firmly believed to be buzzards-because I had read that buzzards are in the habit of making a mewing noise.

But although I never found the nest of either Goshawk or Buzzard, I did-one memorable afternoon-climb up to a nest that looked somewhat different to the scores of squirrel's 'dreys' that I had often hoped might be the nests of some large bird, to find to my unbounded joy that it contained four Sparrow-hawk's eggs-the first I had ever found.

At this time I was already bitten with the mania for taking-or attempting to take-photographs of birds, rather than for the collecting of eggs ; and I really put myself to enormous trouble in fixing a dummy camera in an adjacent tree, so that the sparrow-hawks might become accustomed to the unusual object.

So many times did I go to inspect this dummy camera, and so many branches did I smash off on my journeys up and down the tree, that eventually the place bore the appearance of a piece of common land after a recent gipsy encampment-and the tree looked like a well-worn brown bear's pole.

Of course the inevitable happened. The attention of the gamekeeper of the place was drawn to the tree by its unnatural appearance and surroundings, and the nest was discovered by the birds' very worst enemy.

The female Sparrow-hawk was only allowed to live a few short days longer, before being shot as she returned to the nest to attend to a family of newlyhatched young; and then joined a row of decaying stoats, hedgehogs, weasels and owls on the keeper's scrag-pole.

And such is the inglorious end of a pitiable number of the most courageous of our hawks.

However, it is an ill wind that blows nobody good ; and the empty sparrow- 
hawk's nest was tenanted in the following year by a pair of Long-eared Owls.

These weird, cat-like birds do not build a nest of their own, but, like the Hobby, lay their eggs in the disused nest of some other bird-often a crow or magpie-and sometimes even on an old squirrel's drey.

I have never found their eggs in a wood-pigeon's nest, and should hardly have thought such a flimsy collection of twigs a suitable receptacle, but it is said that they frequently do appropriate such a home.

The fact that the Sparrow-hawk's nest had been taken over by the owls was first discovered, when, on passing through the wood, we happened to glance up at the ill-fated nest, to see a small head with projecting ears looking over its edge at us.

Yet once more the branchless trunk was negotiated, and when I had ascended about half the distance to the nest, the owl flew silently off, and quickly disappeared amongst the innumerable pine stems.

Instead of the richly blotched eggs of the Sparrow-hawk, the nest now contained four pure white ones of the Long-eared Owl ; laid upon the small twigs, and fir needles that had fallen upon the nest during its tenantless months, intermixed with a few of the Owl's breast feathers.

It is rather remarkable perhaps that these eggs were discovered on May 12th-for it is generally understood that the Long-eared Owl lays her eggs in March, or very early in April-and as far as my experience goes, generally does so.

In due course, four of the Owl's eggs hatched, the young ones, contrary to the usually accepted theory, varying but little in size.

For it has been stated by many authorities that, owing to the fact that owls, including the Long-eared variety, invariably commence to sit from the moment that the first egg is laid, they always hatch their young at such long intervals that, by the time the eldest is almost fully fledged, the youngest has only just emerged from the egg.

The words 'always and never' are however dangerous to use where natural-history subjects are concerned, and I have frequently discovered nests of Little, Tawny, Barn, or Long-eared Owls containing families of young, amongst which there has been no more diversity of size than among a normal family of Kestrels-and one often finds that the eldest of a family of these little hawks is somewhat further advanced than his brothers and sisters.

Photography of the young owls was not attempted until they were about half-grown, when it was found that the nest only contained two young !

At first I wondered whether the missing two had tumbled out, or had been carried off by some enemy; but eventually discovered them sitting side by side at the top of a dark pine-tree, at about sixty yards from the nest.

I have since noticed repeatedly that young Long-eared Owls are peculiarly addicted to this habit of clambering about in the branches above the nest 


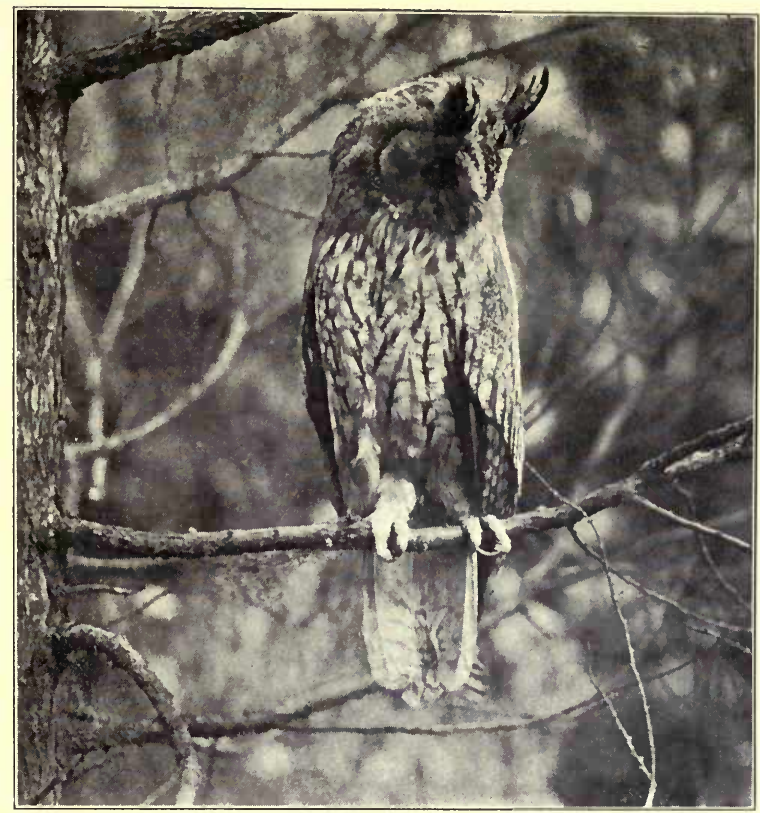

THE

LONG-EARED

OWL

Suspicious-

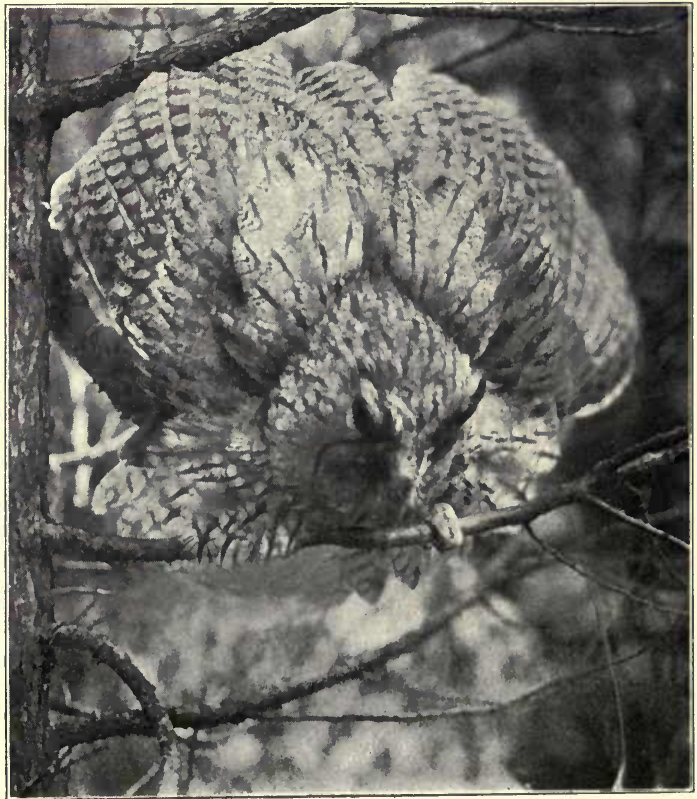

-and thoroughly alarmed 
long before they can fly, and, like young herons, use their beaks with good effect in the process.

The characteristic of preferring some convenient branch to the more comfortable-looking nest would seem to be typical of them, and it is owing to this peculiarity that one so often finds them at a distance from the nest; and not, I think, that the parent owls carry their young in their feet from one place to another.

In the woods which they frequent one may more often find one of them sitting still as a stone amongst the dark branches above the nest than remaining as one of a contented family upon the scene of his hatching. Such little peregrinations lead to their somehow reaching the extended arms of the next tree, and the next, until-at least as far as their human admirers are concernedthey are lost amongst the shadows.

But that the parents are able and ready to find and feed any member of their family who happens thus to stray to a distance is shown by the following incident-for the truth of which I can personally vouch.

Some boys, walking one day through the pine woods in which lay their home, saw sitting in one of the trees the motionless form of a young, though almost fully fledged, Long-eared Owl. At once, of course, an altercation took place as to how it was to be captured, the ultimate decision being that it should be driven from perch to perch until tired out and persuaded to flutter earthwards.

And at length, by driving it with the aid of clods of earth and sticks, from the larger trees, and shaking it out of the thinner ones, they managed to bring it to earth, and needless to say, carried it home in triumph ; the question of food for it not apparently having occurred to them.

So it was placed in a rabbit-hutch in the garden, with the possibility of receiving some scraps of butcher's meat on the morrow.

Next morning, however, ranged along in a row just outside the wire netting of its cage, were the bodies of some ive or six small birds-mostly greenfinches, which were, no doubt, in excess of the young owl's requirements-for it had already fed well.

Each night a fresh supply of birds was laid in the same place by the old Owl, who was in daytime generally hanging about in the trees close by.

In fact, not only did she remain in the vicinity, but she would actually answer the tenant of the cottage when he called to her.

'Jummy,' he would shout, 'are you there?' and a faint mewing from the shadows of the pines would answer him.

But to return to the two owls on the nest. I found that they had grown very considerably since $I$ last saw them, and had reached the age when, instinctively recognizing a human being as an enemy, they endeavour to make themselves as big and fearful as possible in order to deter the visitor from approaching too closely. 
The largest of the two puffed herself up to an enormous size, and with half-spread raised wings and lowered head, swayed slowly from side to side, at the same time uttering a queer snapping noise with her beak. Should a hand be outstretched towards her, she immediately gave a convulsive jerk in its direction, and redoubled her beak snappings.

I noticed that the smaller of the two seemed for a time rather at a loss to understand the meaning of the display; but at last he too raised his wings over his back, puffed up his feathers, and snapped his beak.

His attempt at looking fierce was not very successful; for, perhaps in his anxiety to copy exactly his sister's attitude, he forgot to face the enemy, and as seen in one of the illustrations, did his display sideways! But still, either of these young owls would put up a good fight if the intruder should attempt to take hold of him, his method of defence being to throw himself on his back, and use both beak and talons with the utmost freedom.

No attempt on this occasion was made to secure a photograph of the parent owl-not, however, for the reason that she would be unlikely to fly in daylight; but because the light was so poor in such a situation that it is doubtful if one could have given a sufficiently fast exposure to obtain a really good result.

It is a mistaken idea to suppose that owls can only see in the dark; in fact, of recent years, probably owing to the shortage of mice, Barn Owls have commonly been seen hawking in the daytime, and I remember seeing one return in sunlight to her nest with a starling in her talons.

The Long-eared Owl too will hunt by day, and on one occasion, whilst trying for some photographs of one of them who had taken over an old crow's nest in an oak tree (a somewhat unusual position), I actually saw her return to the tree with a cock-sparrow, which she laid on the side of the nest, and which is shown in one of the accompanying illustrations. This occurred in the middle of the day.

I mention these incidents because the opinion is sometimes expressed that owls can only see vaguely in daylight, and that when being ' mobbed' by small birds, they are-what with the chattering of their pursuers and the demoralizing effect of the sunlight, completely at sea.

I am inclined to think that they merely ignore such noisy fry as chaffinches, tits, and warblers, and that they are flustered only when the aggressors consist of such spirited fliers as missel-thrushes, jackdaws, or plover. And even then the owl usually keeps his head sufficiently to reach his destination without going far out of his course.

Although the Long-eared Owl, like the Sparrow-hawk, feeds largely upon small birds, it does not trouble much about plucking them; the prey is merely pulled to pieces and bolted, feathers and all, with as little delay as possible.

After a meal the Long-eared Owl will often sit motionless for hours together; during such periods it has a quaint habit of-as it were-sleeping 


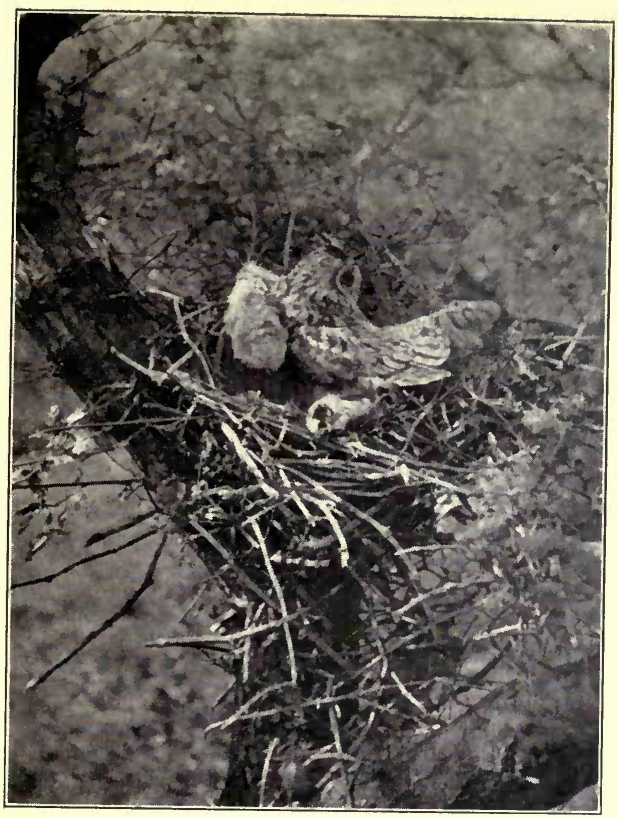

A IONG-EAREI) OWL

AND HER SINGIE YOUNGSTER

[A cock sparrow is lying on the nest.]

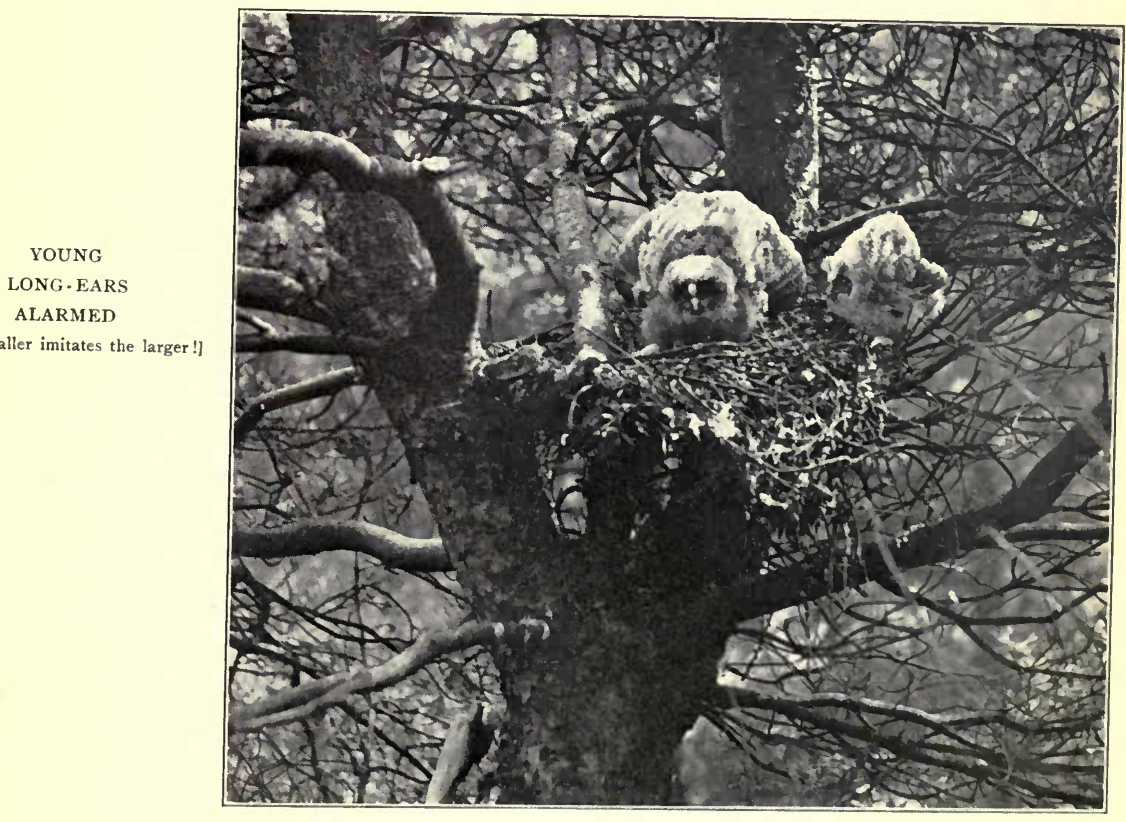



' with one eye open,' for while one eye is completely closed, the other is as wide open and startling as ever.

So well does the plumage of a Long-eared Owl harmonize with the gloomy surroundings as he sits in the darkest shadows of a pine, that it is often an extremely difficult matter to discern him at all; particularly as the owl, by drawing its wing round it like a cloak, and making itself appear as thin and inconspicuous as possible, looks for all the world like a piece of dead wood that has lodged in the tree; and a very different creature from the same Owl with feathers erected, in the act of 'displaying.'

In those pine woods which the Long-eared Owl haunts, one may usually expect to find the nest of another bird, which also, in the nesting season, at least, conceals its presence behind a cloak of silence and stealth; the jay, to wit.

One can generally judge when the young jays are on the wing by the loud squawkings and chatterings that issue from the wood; yet as long as they are in the nest they and their parents observe a complete and discreet silence.

Whilst photographing a jay and her young during the past summer, I noticed that the only sound which the old birds uttered was a high-pitched, soft mewing cry-which I had not heard before. The young ones seemed unable to express their feelings verbally except by an indistinct noise. Yet, almost as they left the nest, they commenced their harsh jay calls.

The jay, like the magpie, sits exceedingly tightly whilst brooding her eggs; and one wonders whether she does so in order to escape observation. For a jay, squeezed so tightly on to her nest that only her tail and the tip of her beak are visible, will refuse to move until some very real danger threatens her, such as an outstretched hand within a few inches of her back.

But, if frightened off the nest, and convinced of the fact that she has been discovered, she may spend some hours in making up her mind that she will return again.

And so the jay, whose habits are so retiring, is comparatively seldom seen. When it is seen, there is no mistaking it however, for as it flies away the black tail and white tail coverts distinguish it from other birds that might occur in the locality.

Since the war, jays have increased to an extraordinary extent in the districts with which I am most familiar, and may be seen at almost any time, in fir forests, among the oaks, or in the meadows. The reason of their having so multiplied is, of course, that the gamekeeping community generally took some part in the war, and thus 'vermin' had a free run for a while, and hawks, stoats, jays, magpies, hedgehogs, and so on multiplied amazingly. In this respect they are the opposite of the little Red Squirrel, which used to be quite common, but which now-alas ! is very seldom seen. 
In fact it is only in the fir forests that one sees them at all in these days ; they seem to have completely forsaken-or been driven from-the great hollow beeches that they used to frequent.

Many a time, in the pre-war days, have I found a squirrel's drey at the top of some fir-tree, containing a family of little ones. On one occasion I put my hand into the hollow of a dead pine thinking that a stock Dove inhabited it, only to find a squirming mass of young squirrels-who came tumbling out, and climbed up the bark of the tree with extraordinary alacrity.

As a rule the family numbers from three to five, so it might seem difficult to say exactly why they should have become so rare in certain localities. I am of the opinion that such a deplorable state of affairs is entirely due to the importation of the American Grey Squirrel.

A few years ago, when the native Red Squirrel so often delighted us with the graceful ease with which it darted along the slimmest larch branches, or leapt from the top of one outstretched limb to the next, the Grey Squirrel was practically unknown; and I well remember my excitement when I first saw one.

But to-day these little animals-which are still very popular in the London parks-have increased to an almost incredible extent. They were of course imported into this country, and liberated in the hope that they would become established as a breeding species, and have responded so generously to the confidence which was placed in them that they have not only become established, but so firmly that they are now considered to be far too numerous, as well as being-it is said-destructive to various trees.

The pity is that these two varieties of squirrel do not seem to be on amicable terms with one another, and it is a significant fact that it is only in those situations where the Grey Squirrel is seldom or never found, that one may expect to see a Red Squirrel to-day.

I have seen scores of grey squirrels recently; I have not seen a single red one. 


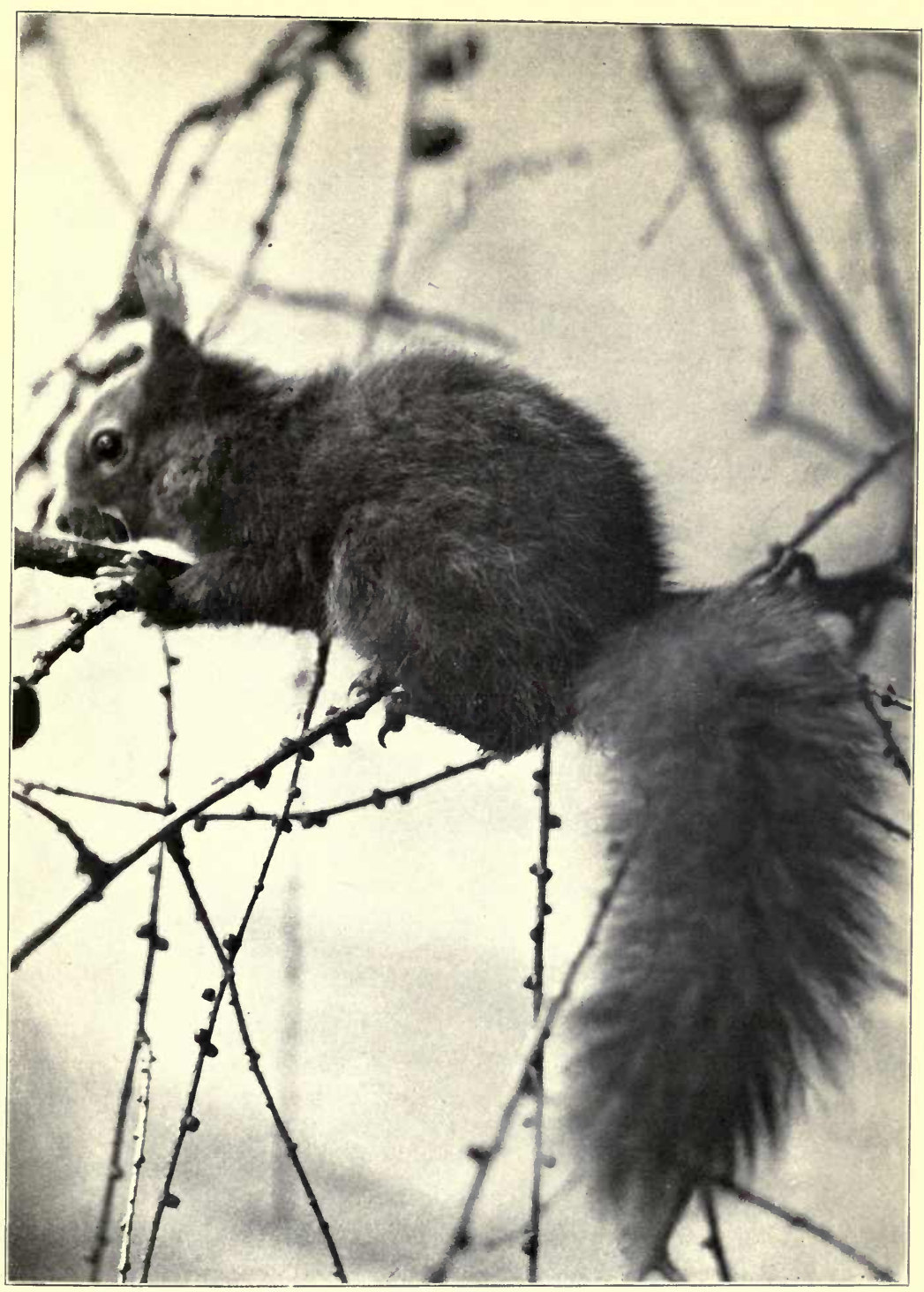

A RED SQUIRREL 



\section{CHAPTER V}

\section{The Greater Spotted Woodpecker}

B

UT there is yet another bird which frequents the fir forests, and which is as attractive even as the green woodpecker of the beech grovesthe Greater Spotted Woodpecker.

The fact that a pair of these wonderfully showy birds is in occupation of a certain wood is generally made obvious by the sharp penetrating cry that they continually utter. This cry may be heard more or less throughout the year, but more particularly in the nesting season-especially if the nest tree is approached at all closely ; and may be likened to the sound produced by striking two pieces of stone together-like the 'chak' of a stonechat, only very much louder.

But although the call may be heard at some distance, and one may be attracted by it towards the bird, it is comparatively seldom that a Greater Spotted Woodpecker is seen at anything like close quarters-unless, indeed, it be flying overhead. For like the Green Woodpecker, it has a habit of remaining hidden by keeping the stem of the tree to which it is elinging between itself and the would-be observer.

There are certain districts in which the Greater Spotted Woodpecker is more numerous than the Green, although in the part of the country with which we are dealing, the latter is the more general. One can usually distinguish the nesting-hole of a Greater Spot by its small size and its somewhat elliptical shape ; that of the Green being a much more decided circle. Then the nesting cavity of the former is usually excavated from completely dead wood, often with the walls so fragile that one could break them away with the fingers; whilst that of the latter is usually dug from the stem of a tree which has, at least, a sound exterior, and into which it would be difficult to break even with a hammer and chisel.

Like the Green Woodpecker, the Greater Spotted does not invariably dig a fresh hole each year, but occasionally deepens the last year's home, and in either case, allows the chips of wood thrown out to remain at the foot of the tree.

It is not an easy matter, however, to discover the nesting-hole of the Greater 
Spot whilst the bird is sitting, for the type of country it frequents is generally covered with a luxuriant undergrowth, by which such chips of wood are effectively concealed ; and one may well walk beneath the tree in which the bird is sitting without suspecting in the least that she is anywhere near.

For the bird is an exceptionally close sitter, almost as much so as the Little Owl, and I have climbed a dead pine tree, at whose base the tell-tale chips were scattered, in the hope of finding the bird sitting in an apparently suitable hole, only to return to earth perplexed and disappointed; for I had blown into the hole, and laying my ear to it had listened carefully without detecting the least suspicion of movement inside.

Later in the season, however, I discovered that the young had been hatched in an old hole, some 2 feet further up, and in which the Woodpecker must have been sitting whilst I climbed the shaky tree almost to her nest.

The eggs of the Greater Spotted Woodpecker are, like those of the Green, glossy and pure white-although whilst fresh, the yolk inside imparts to them a pinkish tinge which is very beautiful. They usually number from four to six, though as many as eight have been reported. The enthusiastic oologist is sometimes terribly disappointed, after having spent some hours in digging out a Greater Spotted Woodpecker's hole, to find, when at last he is able to reach and withdraw one of the eggs, that it is nothing more unusual than a vulgar starling's!

Starlings are, of course, just as ready to appropriate such a convenient home as any other, regardless of how it may have been formed, and a useful method of ascertaining whether a pair of them is in possession is to climb the tree, and sniff at the entrance to the nest-the distinctive scent of the starling will quickly solve the problem.

When the young woodpeckers are hatched, it is not a very difficult matter to locate them-providing of course that the old birds are known to be about, -for they keep up an almost constant chittering, which increases in vehemence as the parent bird approaches them, and may be heard at a considerable distance. Should the young be left for an unusually long time, this metallic note will gradually subside to an almost inaudible whisper, as though, tired of calling for food, they have dropped off into a comfortable doze.

This little chittering cry is very similar to the sound which issues from a Noctule Bats' den, when the occupants are preparing for the evening fly; in fact, I have more than once mistaken one for the other. As the young woodpeckers grow this cry develops into a series of sharp little cries-a youthful imitation as it were of the call of the parents-gradually merging into a prolonged repetition 'chip-chip-chip'-which one can imitate very fairly by striking two pennies together. Not until the young woodpeckers are almost ready to fly, however, is their cry really resonant and determined, and at that 


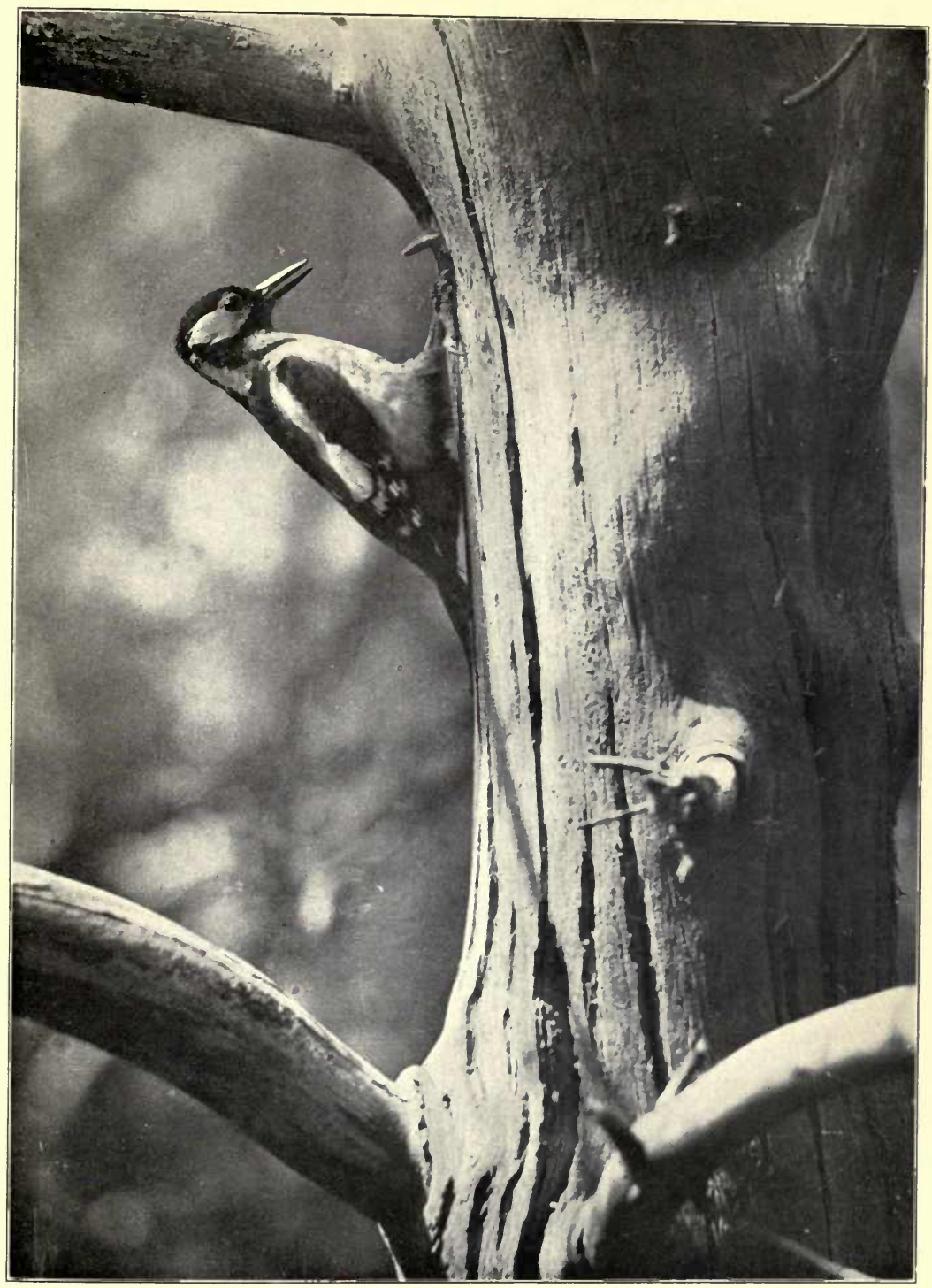

THE CIREAT SPOT'TED WOODPECKER

[A youngster's beak is protruding from the nest-hole.] 

stage, as in the case of the Green Woodpeckers, the sound must act as a guide to the old birds.

The bird figuring in the accompanying illustration had laid her eggs in a freshly dug nole, although the chips which she had thrown out were completely hidden by the bracken growing at the base of the tree, and would have escaped notice altogether if they had not been looked for.

The nest was first discovered on May 24th-and by a queer accident; for I chanced to strike the stem of a tree in which was a sparrow-hawk's nest, merely to satisfy myself-if the hawk should fly off-that she had not suffered the usual fate. To my surprise, I saw passing an opening in the trees not only the sparrow-hawk, but at the same moment a Greater Spotted Woodpecker.

Here indeed was good fortune, for though the sparrow-hawk's nest was in a hopelessly dark position for photographic purposes-the Woodpecker's, although perhaps unusually high up-some 55 or 60 feet-was beautifully situated, as far as lighting was concerned, particularly since it was in a fir wood ; an advantage that was greatly enhanced by the fact that the nesting-hole was at the extreme top of the tree. Had it been lower, it would undoubtedly have been correspondingly badly lit.

And there is another very distinct advantage about trying for photographs of a bird whose nest is at a great height from the ground, and that is the fact that people who, passing beneath, happen to see the imitation camera or the observation post, do not usually feel inclined to climb up and interfere with it. There is nothing more exasperating than to find that some of the youths who are so frequently to be seen wandering aimlessly about the country on a Sunday afternoon, have taken the eggs or killed the young birds, and thrown out the imitation camera.

The Woodpecker having sat so closely upon her young ones-who as she left at once began their weird little bat notes-pointed to the fact that they were newly hatched, or at any rate very small; for had they been more than a week old, she would not have been brooding, and would only have gone into the hole to feed them.

Consequently I judged that we had, in all probability, a couple of weeks in which to arrange, and accustom her to, a dummy camera. So without delay I collected a bundle of bracken and some dead branches, which were to serve as an imitation camera, and commenced to climb the tree in which the actual camera would ultimately be fixed. When I ascended, the chittering of the young woodpeckers grew louder as the distance between us lessened, and I wondered anxiously whether two weeks would not be too long a time to elapse before trying for some photographs.

However, I decided that they could only have been recently hatched, and consequently that they ought not to be on the wing for about three weeks. 
There was little doubt about the parent woodpecker's anxiety to return to them, for she flew from tree to tree constantly, uttering her alarm note 'Tchak'!

Owing to bad weather, photography was impossible-especially in the fir woods-until three weeks had elapsed, and it was really by exceptionally good luck, as it turned out, that the young woodpeckers had not, by that time, already flown. That they had arrived at the age when they were on the verge of leaving the nest was evident by their loud chipping cries, and the continual appearance of first one and then another little head, which peered inquiringly out from the hole.

As is so often the case, an unconscionably long time was taken in fixing the camera, and in persuading it to point in the required direction; in fact, after almost an hour of unsuccessful effort, I fear that I felt thoroughly weary and exasperated.

My annoyance was increased by a glance below, which revealed my companions reclining easily amidst the cool shade of the ferns, lazily smoking cigarettes, and laughing carelessly over their-it seemed to me—foolish remarks !

Assuming as pleasant a voice as I could under the circumstances, I shouted down to them to ask if they had completed the hiding-place. At once their three pink faces gazed up at me from amongst the bracken, while they complacently replied that everything was ready long ago. Nevertheless, I noticed that they immediately commenced to be busily engaged-no doubt to smooth over my ruffled feelings !

So there was nothing for it but to continue my endeavours, and at length the camera was securely fixed; the nest focused; a string run from the shutter, through a series of 'screw-eyes' to the foot of the tree, and thence to the hiding-place ; the shutter set; the dark-slide withdrawn, and the whole affair properly camouflaged.

And then at last, after an easy slide-except for the risk of inadvertently pulling the string-down the now polished stem of the tree, to terra firma, I entered the cool shadow of the hiding-place, where at least I could stretch my cramped limbs and recover from my recent exertions.

My companions having 'covered me in,' now prepared to depart, the arrangement being that they should not return until either I let them know that I had made some exposures, or the light began to fail. And when their voices, and the sound of snapping twigs as they waded through the undergrowth, had faded into the distance, I glanced through one of the many peep-holes to see if either of the woodpeckers were anywhere in sight. For a time I neither saw nor heard anything-but was presently informed of the fact that one of them was close at hand, by a loud ' chak,' which sounded from the tree immediately above my head.

But although the bird must have been within a few yards of me I could not see her, and in fact, was so anxious that she should not suspect my presence 
that I dared not even turn my head in an endeavour to see what she was doing.

Presently I heard a ' chak' from somewhere behind me, then it sounded from my left, then my right, and again from above. Could it be that the woodpeckers were suspicious of the 'hide'? For now both of them were ' chakking' energetically.

As time went on my anxiety increased. The Woodpeckers continued to fly from tree to tree uttering their alarm note, which was repeated at intervals of about twenty seconds. Something was evidently amiss, and at last the disquieting conviction was forced upon me that these keen-eyed birds actually did know that I was in hiding in the heap of bracken. Should I change my hiding-place, or give them another ten minutes?

It was one of the woodpeckers which settled the problem for me, for it settled on the ground less than two yards from my head, peered in at me as though to satisfy itself that I really was there, and then with an ear-splitting ' chak-a-a-a-a-a,' was off like a rifle bullet.

Without doubt a fresh hiding-place must be made-and that without delay. So, somewhat ignominiously, I crawled forth, and to the accompaniment of the excited chattering of the woodpeckers, looked about me for the best position.

The building of this new hiding-place really consisted of transporting the branches and bracken of which the first was constructed to another, and perhaps less obvious, situation. And having completed it, and satisfactorily arranged the string from the camera, the question arose as to how I was to retire without being seen by my watchful subjects.

From my new position I could clearly see the Woodpecker's hole, from which occasionally a youngster's head peered out, bending this way and that, and chipping inquiringly. Doubtless it resented such unusual delay in the delivery of rations.

This, however, was not what I wanted. Somehow or other a scheme must be devised which would trick the Woodpeckers into thinking that I had gone aw? y, or vanished into the earth. For a while I gazed around blankly, half inclined to walk noisily away for $\mathbf{1 0 0}$ yards or so, and then return on hands and knees to my shelter. Then I thought of the dead stem of a fir tree some twenty feet away. Perhaps if I set it swaying in a sufficiently alarming fashion, it might tend to distract the bird's attention from myself. At least it was worth trying; for the only other alternative was to go in search of my companions-and they might well be, by this time, a couple of miles away.

So I walked up to the dead fir stem, and found that, happily, it was in a somewhat precarious state-so much so that a series of mighty pushes soon set it swaying in the most apprehensive manner. Then as quickly as possible, I stole back to my hiding-place, and whilst the dead tree gradually ceased its rocking, awaited events. 
As it turned out-though whether or no results were due to the tree-swaying idea it is impossible to say-the woodpeckers did overlook my presence; for soon their excited alarm cries changed from the angry 'chak' to a lower and more liquid 'quip,' much like that of a sparrow-hawk when she calls in a subdued way to her young; and in less than ten minutes, I saw one of them settle on a branch of the home tree, and hesitate for a while as though half expecting that something fearful would occur.

Needless to say, I was much relieved that things had taken such a turn for the better, but perhaps was even more deeply concerned with the manner in which she took perch. For I had never before seen a woodpecker sitting thus - crosswise on the branch like an ordinary perching bird-and had believed that their invariable habit was to cling to the side of the tree, or branch-as indeed is the usual fashion with woodpeckers.

Presently she hopped to the trunk, at a point some four or five feet below the nesting-hole, and supported by her stiff tail feathers, commenced to climb upwards in a series of spasmodic jerks towards the protruding head that was chittering so anxiously above her.

The process of transferring food from her own beak to that of the young seemed to be particularly energetic and rapid-a series of incredibly swift jabs - of which the youngsters must have been quick to avail themselves. When this particular member of the family was temporarily satisfied, he silently withdrew into the depths of his home, and so made room for another, which lost no time in protruding an expectant head-all eagerness for the next consignment of food.

During that morning no less than six photographs of the Woodpecker at the nest were secured; so that a considerable number of journeys up and down the tree, that the camera might be re-arranged, had to be undertaken.

Such constant friction had succeeded in wearing off the loose bark, and the trunk of the tree had become exceedingly slippery. My difficulties were added to by the fact that for some distance there were no branches to help me, and the last climb found me almost despairing of being able to reach the camera at all !

Three days later I again visited the wood, and making my way through the dense bracken towards the woodpecker tree, listened anxiously in the hope of hearing the young ones. I found, however, on reaching the tree, that they had all flown, and since it seemed hopeless to expect to see any more of the family, I decided to give up the idea of trying for further records. I was accordingly preparing to leave the place when I was startled by an unmistakable ' chip' which seemed to come from a tree some 30 yards away. Walking stealthily towards the point from which I judged that the sound issued, I saw one of the young woodpeckers fly quietly from the trunk of one tree to the next, and disappear behind it ! 
THE GREATER SIOTTED WOODPECKER
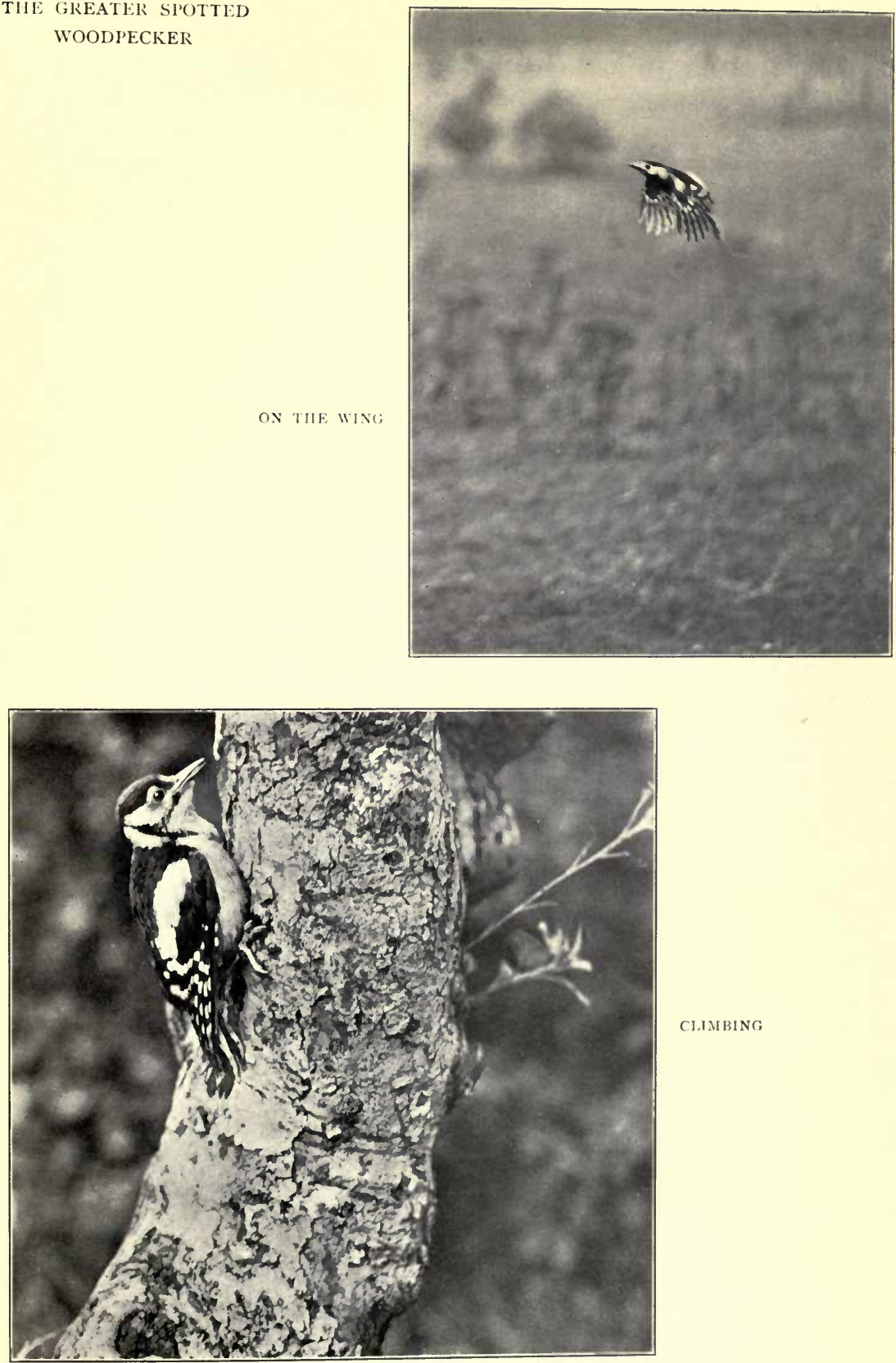

CI.IMBINC 

Advancing as quietly as possible, so as to avoid frightening him, I reached the tree, circled slowly round it with my eyes fixed on its trunk, and sawnothing! I knew that he had not left the tree, and yet I could not, for a time, make him out. At last, however, I spied him, although his black and white plumage, sitting as he was in a patch of bright sunlight, harmonized so well with the high lights and dark shadows of the rough bark to which he was clinging, as to make him wellnigh invisible.

He seemed to realize that I had seen him, for he presently flew to the trunk of the next tree, and disappeared behind it as before. He was, as yet, however, unable to fly strongly, and I think I could have caught him, although he dodged around the tree trunks in the most disconcerting way.

The young of this particular species of Woodpecker differ in one marked respect from the mature birds, in that the entire crown of the head is of a rich searlet colour. In the case of the adult female this colour is entirely absent, the crown of the head being black. The male has also a black crown to his head, with a small scarlet patch at the back.

The food of the Greater Spotted Woodpecker consists mainly־at the time of the year when they are available- of various insects and their larvæ; although during the autumn and winter months they seem to subsist chiefly upon berries, hazel-nuts, and beech-mast.

I recently had an opportunity of watching at close quarters the Greater Spotted Woodpecker's method of splitting open and eating hazel-nuts, an operation that I had not seen before, and which struck me as being unusually interesting.

It was during the early part of September, as I was walking through an ancient and long disused quarry, that my attention was suddenly arrested by a sharp tapping sound which seemed to issue from somewhere ahead of me. At once I stood still, hoping to discover the cause of it-half imagining that it would prove to be a Great Tit, or a Nuthatch. Since the tapping continued, I slowly advanced, but still could see nothing to account for it, although I was now certain that the sound originated in an old and rather decayed sallow tree, of which I was within about 12 yards.

The sound had now ceased, and I was wondering what my next move should be, when to my surprise a Greater Spotted Woodpecker unconcernedly flew from the sallow, and disappeared over the bushes close by. Investigation showed that the foot of the sallow was littered with the shells of hazelnuts and their green husks.

In each case larger or smaller pieces had been split from the side of the nutshell towards the smaller end, and the inside of the nut pretty carefully removed, although in some cases a little of the nut, dented by the beak of the woodpecker, still remained in position.

Without further delay I concealed myself in the undergrowth in the hope 
that the bird would return again. Hardly had I done so than she made her appearance with a hazel-nut, to which the green husk was still attached, held in her beak. Settling without hesitation, she hopped up the inclined trunk of the tree, and placing the nut in a little cavity on the upper side of one of the branches, she proceeded by sharp blows of her beak to split it open.

This she soon succeeded in doing, and having thus made preparation, commenced to remove the contents by rapid and extremely vigorous digs of her beak-incidentally wasting a considerable amount in the process. When she had emptied the shell, she threw it overboard with a sideways jerk of her head, and once more flew off, to settle this time in a hazel bush some 30 yards away.

Here a hunt for another nut took place. A hunt which involved some curious contortions; for she hung upside down from the extreme tips of the leafy twigs, and having found a nut, she set to work to twist it from its cluster with the most energetic movements of her head and neck, and a considerable amount of fluttering. Eventually she succeeded in wrenching it free, and at once returned to place it in the little cavity in the sallow. She seemed, however, to be dissatisfied with the fit, and accordingly picked it out again with the tip of her beak, and hopped some 10 inches further up the stem of the tree to another groove which was fortunately in a much better position from my point of view. In fact I could distinctly see the crimson cap to her head, which proved she was a bird of the year; the way in which she pressed the nut into position, with its edge towards her; and the rearrangement of it when it slipped sideways at the first stroke of her bill.

This incident occurred some years ago, but I have noticed that each year at about the beginning of September, this woodpecker, or another, returns to the same sallow for the purpose of feasting upon the hazels.

These woodpeckers deal with oak-galls in the same way, placing them in a crevice of the rough bark of some tree, or in some suitable cavity, and splitting them open, so that the larvæ within are exposed.

It is not very generally known, perhaps, that the Greater Spotted Woodpecker is partial to apple pips, although this fact is not surprising when it is considered that they are known to feed largely, on the continent at least, upon the seeds contained in fir cones.

Personally I have only once seen one of them at all interested in apples, and on that occasion the bird was flying from an orchard with a rather small apple-rather suggesting what, in America, is called a 'toffee apple'impaled on the tip of its beak.

Although this woodpecker is provided with an extendible tongue, it seems not to make so much use of it as does the Green Woodpecker, which latter bird finds such a contrivance of the greatest possible use in extracting ants from their underground quarters. 
The Greater Spotted Woodpecker may be, if handled in the same manner as a hawk, comparatively easily tamed, and in fact may grow so attached to its owner that it dislikes leaving his side.

I have had one of them which, if held in the hand and tossed high into the air, would plane down with the most perfect ease to settle again upon my coat sleeve.

If at all hungry this woodpecker would continually utter its sharp cry, and developed an unhappy knack of demanding food by rapping painfully against one's hand or neck with its beak.

Since it was allowed entire freedom, and soon learned to fend for itself, it ultimately reverted to the wild state. It would indeed be interesting to know whether it travelled far afield, or whether it nested in the neighbourhood of its former human friends. 



\section{CHAPTER VI \\ The Swiftest of British Hawks}

TOR many years I hoped that one day I should discover the nest of a Hobby-so that I might watch in the live free state the habits and manner of flying of this delightful little Falcon-but, in spite of protracted inquiries and diligent searchings, it was not until quite recently that this ambition was fulfilled.

I had, of course, in my youthful days passed through the phase of discovering in Kent the nests of such birds as Nutcrackers, Twites, Snowy Owls, and so forth, and on one occasion firmly believed that I had discovered that of a pair of Hobbies.

I was walking with a gamekeeper one cloudless April morning when I chanced to see a hawk perched on the very tip-top twig of a tall, dead ash tree. For a while we stood and watched it, but we were really too far away to form any idea as to the colour of its plumage, and consequently decided to approach to closer quarters.

As we crossed an open space the hawk, catching sight of us, spread its wings and tail, and soared into the air. 'What long wings it has !' I remarked excitedly to my friend. 'And how blue it is! Whatever kind of hawk can it be ?' He said he thought it must be a blue French hawk, and ihat he knew there were some about as he had shot one, and had it stuffed in a case, at home.

Needless to say, my excitement was now approaching the state of feverishness, and I begged that we should go forward and see if there was a nest. My companion remembered that there was an old magpie's nest at about the point from which the hawk flew, and we accordingly set out on a tour of investigation.

Surely enough, there was the magpie's nest, from which, as we drew near, a second hawk flew.

My joy knew no bounds, and although the nest was at the top of a very high oak, I managed to climb up to it, and found that it contained three eggs - very richly marked with dark red and purple blotches.

Certainly these were the finest eggs I had ever seen, and most surely belonged to some very rare bird. Incidentally, they were the first hawk's eggs of any kind I had ever discovered!

On my return home I consulted all of the bird books in my possession, and studied the coloured plates of birds' eggs in order to try and identify what I 
had found, and at last came to the definite conclusion that they were Hobby's eggs. The question of the possibility of their being Kestrel's eggs was raised, I believe, but the idea was laid on one side as being absurd.

In the first place there were only three eggs, and Kestrels usually lay five to six. Then they were laid in an old magpie's nest; and Hobbies, I learnt, love to take over such a home; also the first of the two birds which I had seen was distinctly blue-and the stuffed Kestrel in the second-hand bookshop was a reddish colour, much dotted with black spots and bars. And lastly, had I not remarked on the length of the hawk's wings? And I learnt that the Hobby is the longest winged of all our hawks.

What I did not then know is, that the Kestrel also sometimes lays only three eggs (and even if she is going to lay six-there must be a time at which the nest only contains three!); that the Kestrel also frequently appropriates a disused magpie's nest ; that the mature male Kestrel is of an entirely different colour from the female, and has a slaty-blue tail ; and that the length of the Hobby's wings is much greater than those of the hawk I had seen leave the dead tree-top. In addition I now know that the Hobby is a migratory bird, and so late a nester that one cannot expect to find its eggs before the middle of June.

The Hobby is, in fact, a very rare bird, although, like the Buzzard and the Merlin, it returns annually to its breeding-places, which are, in the instances with which I am acquainted, in isolated clumps of trees in extremely open country.

There is no mistaking a Hobby by those who are familiar with the various small British hawks, even if it be flying at a great height ; for the extraordinary length of its wings lends to it something of the appearance of a swift. When it is at rest, it is an even easier matter to identify it-for once more the length of its wings strikes one immediately-they really seem almost out of proportion!-whilst the black crown of the head, the pure white cheeks, the greyish black of the back, and the almost orange patch on the thighs, distinguish it at once from any other British hawk. We are told that, in the days when Falconry was so popular a sport, Hobbies were very highly esteemed as birds of great wing power, courage, and tractability, and that they were trained to take such large fowl as pigeons and partridges; but in these modern times, perhaps owing to the fact that the art of training them is a lost one, none of the modern Falconers seem to have been able to do the least good with them. It is doubtful in fact whether they enjoy a better reputation than the poor Buzzard! In any case, they are usually termed dull, spiritless, cowardly, and so on. It is possible that this apparent laziness on the part of the Hobby is due to the fact that in the wild state it consumes, like the Kestrel, a quantity of winged insects, May bugs, dragon-flies, and the like; and the fact that it spends a considerable part of its time soaring at vast heights, from which 
point of vantage it would have little difficulty in overtaking the very swiftest of our smaller birds. In fact I am told by a famous modern Falconer that in Hungary, where Hobbies are common, he has quite frequently seen them take swallows in the air. A feat that none other of our British hawks would ever try to accomplish.

It is my intention to set down in the following pages my perhaps extraordinary experiences with a pair of Hobbies and their nest, in the hope that the opinion of the reader regarding these birds will be a happier one than if it were based on the books on Falconry.

It was not until the year 1920 that I was fortunate enough to find a Hobby's nest, and when I first gazed up at it from the earth below, I came to the conclusion that to secure photographs of it would be impossible; for the Hobby had selected a disused crow's nest at the top of a pine tree, which was so high that it stood out conspicuously from among the other trees close at hand.

However, I decided to try to reach the nest and to find out what it contained, for it would be useless to think of arranging for photography if, for instance, the hawk had not finished laying.

The task of climbing the tree, however, was by no means an easy one, for the trunk of it was smooth and straight for thirty feet, and to add to the difficulties, a steady misty rain was falling, which made the tree slippery, and the progress consequently most wearingly slow. Still at length the lowest branch was reached, and after a brief rest the ascent continued. I found that the nest contained three eggs, which were by all appearances fairly hard set : and noting that the female Hobby, which was flying round screaming, seemed anxious to return, I slid down to earth with all speed, and left the place without further delay.

Whilst at the nest, however, I had decided that the only possible position from which photographs of the nest and its inmates could be obtained was the top of a straggling beech, whose branches, I had noted, were swaying obediently to each passing gust of wind.

But having waited so long, the opportunity of securing photographs of a Hobby's nest could not be treated too lightly, and the beech-if things were well-would necessarily be utilized.

Some week later, therefore, - on the sixteenth of July to be precise-I again visited the place, and found that the eggs had hatched, and that there were three charming little Hobbies in the nest. As quickly and quietly as possible I descended to earth, and having gathered together my impedimenta commenced to climb the beech tree. I had brought with me a length of rope with which to lash together some of the beech boughs, as I felt sure that one of them alone would not be sufficiently rigid to support the camera - certainly not to bear my own weight.

To make matters worse, a gale was blowing, and when I had got as high 
as I dared, I found that it was impossible to do anything-for the branches were swaying and bending in the most alarming manner. The fact of roping together as tightly as possible three of the upright beech branches had the effect of steadying them somewhat, and as I fixed into position a 'dummy' camera, I devoutly hoped that the weather conditions might improve by the time photography should be attempted. Whilst fixing this imitation camera, I saw the female Hobby dash out from the trees, and give chase to one of the Peregrines which were flying at hack, ${ }^{1}$ and which seemed quite scared at her screaming and at her powerful stoops.

The tinkling of a Peregrine's bell would be a certain signal for the appearance of the Hobby, who never allows one of them to come within less than about eighty yards of her nest.

Unhappily the weather conditions did not improve, so I had to prepare to make the best of things, and on July 22nd, tried for some photographs. The weather, however, was every bit as bad as it had been during the previous visit, and the light was, if anything, worse.

Before climbing the beech to fix the camera, I clapped my hands with the idea of sending the Hobby away, so that she should not see me climb the tree; and became somewhat anxious when she did not go off. However, when half-way up to the camera position, I was much relieved to see her swing away from the nest and settle on a dead branch some ninety yards off, whence she could watch my movements. From the camera position I could look across on to the nest and could see the young Hobbies-little balls of downwatching me with their dark eyes. Owing to the high wind that was whistling over the hill and through the branches, an unusually long time was taken in fixing the camera, and when it was in position I had the greatest difficulty in focussing on the nest; the camera and myself swaying from side to side, and backwards and forwards, in such a manner as to make it almost impossible to persuade the nest to remain in the picture at all.

But at last things seemed satisfactorily arranged, and I had just made the final adjustments when, glancing at the Hobby's nest, I saw, to my amazement, that the female Hobby had returned to her young and was at the moment shuffling herself over them, just as a chicken shuffles herself over her eggs-and all the while looking directly at me!

Needless to say, I exposed one of the two plates that I had with me. I thought that perhaps she had not noticed me, and that at any moment she might dash screaming off the nest. Nevertheless I reset the shutter, changed my dark-slides, and exposed another plate.

Now I was placed in a quandary, for I hardly dared to risk frightening the hawk by climbing down the tree-but I had no more plates with me.

1 Young Peregrines before being reclaimed and trained are 'flown at hack' (or allowed absolute freedom) for some five or six weeks. 


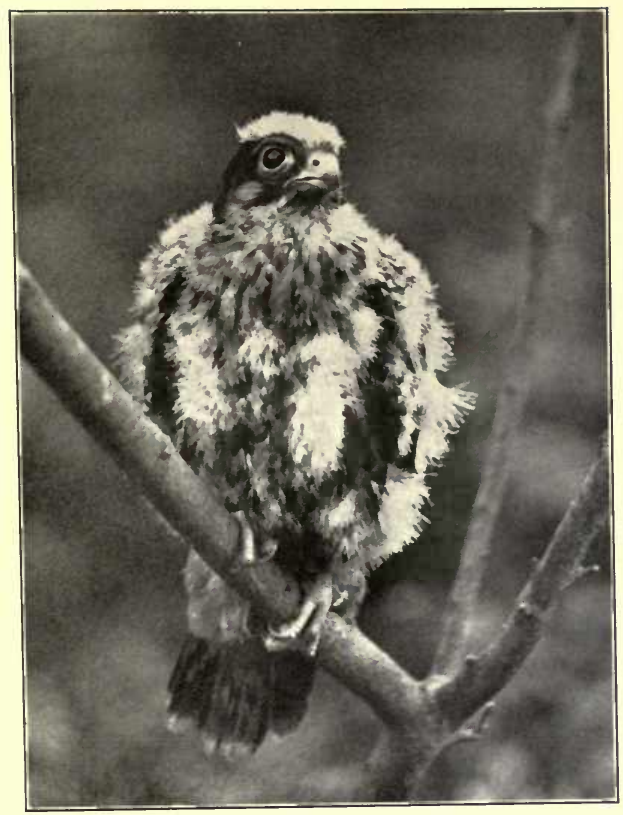

STUDIES OF THE

YOUNG HOBBIES

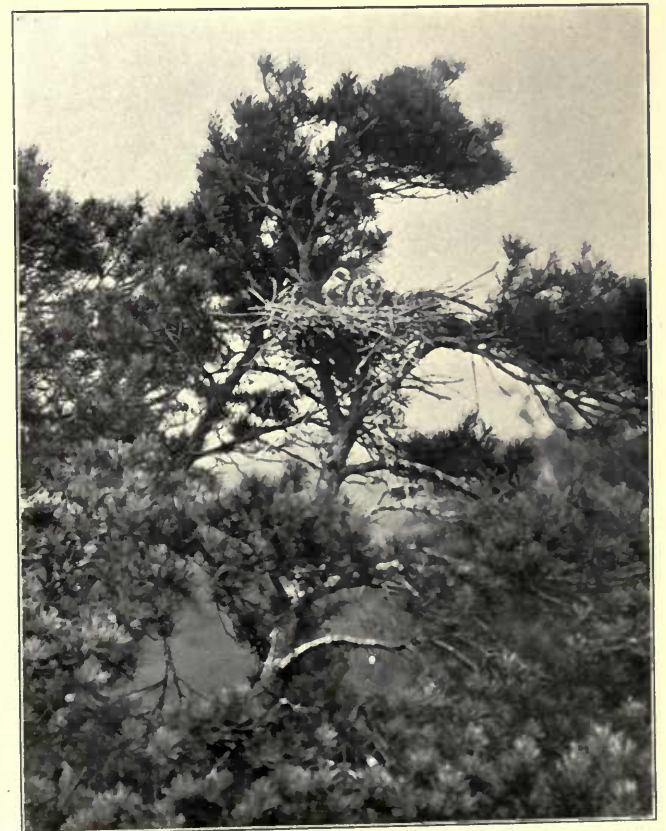



And meanwhile the Hobby continued to brood her young!

So at length I decided to run the risk of frightening her by descending for a fresh supply of plates. As I began the journey the Hobby flew from the nest, and returning to her perch on the dead branch commenced to scream at intervals.

As a matter of fact, she kept up this intermittent screaming for almost twenty minutes, and hoping to reassure her, I walked out into the open as though I were going away. Her screaming then ceased, and I decided after a wait of half an hour to climb up to the camera, and to put another dark-slide in position for a third exposure. When I was high enough in the beech to see across to the nest I saw that the Hobby was covering the young again, and was still peering in my direction.

Now I had noticed that when I walked away into the open she had continued to sit on her dead branch perch until I stopped, and turned to look at her, when she immediately flew off; and the idea of covering up my facewhich was seemingly so repellent to her-suddenly occurred to me.

I consequently snapped off some beech boughs, and sticking some of them in the band of the disreputable felt hat that I was wearing, and allowing others to hang down from under it over my face, I continued my journey to the camera.

This ruse of course, seems at first to be exceedingly ridiculous, but we have heard of camouflage effects having been employed successfully on other and more serious occasions, and it might, at least, lessen the chances of the Hobby being unduly terrified.

In any case, the plan was completely successful, the only sort of protest which the little hawk offered being a little feeble screaming. Having exposed my two plates-without causing the Hobby the least anxiety-I realized that I had stupidly left the last remaining dark-slide down below !

Once more I crept down the tree, this time without disturbing the Hobby, got my dark-slide and returned to the camera-to find her still on the nest ! So once again I got everything in readiness for an exposure, and clinging on in a most uncomfortable position, and swaying this way and that, I waited for my little friend to do something interesting.

After a wait of some twenty minutes, I heard the male uttering a protracted call, very like that which a Kestrel makes when he brings food for the female. She answered him at once, and, leaving the nest, flew to him as he sat on a branch with a small bird in his talons.

This she took from him, and returning with it to the nest commenced to tear off small pieces, which she distributed amongst her little family. When it was all finished she cleaned her beak on the edge of the nest, and then shuffled forward as though to brood the young ones. I noticed, however, that two of them continued to peck at her beak in a persistent way as though not satisfied with the amount of food they had received. The old Hobby seemed to under- 
stand what was required, for she began to move her head and neck as though she were about to eject a casting. Presently she disgorged a piece of meat from her crop, and holding it in her beak, allowed the young ones to peck tiny pieces from it. When they were at last satisfied, she stepped from the edge of the nest where she had been standing, into the centre, and crouching down, induced the young ones by 'hooking' them towards her with her head and neck, to take shelter under her breast feathers.

Whilst she was brooding them her beautiful wings, which reached to some distance beyond the tip of her tail, were almost half-open, with the primaries (or long flight feathers) pointing slightly upwards.

Having exposed all my plates, I climbed down the tree without disturbing her, cycled back to the village where a fresh supply of plates was awaiting me, refilled my dark-slides, cycled back to the wood, and actually climbed up to the camera without causing the Hobby to leave her family. She was facing me as I climbed the tree, and I could see her bright eyes, white cheeks, and black moustaches distinctly. And still she remained brooding; in fact she seemed now to be so accustomed to my presence as to be quite unconcerned about me.

It occurred to me, as I waited by the camera and watched the little hawk, that it would make an unusual photograph if I could 'snap her in mid-air,' and so, opening the lens to its fullest aperture, and setting the focal-plane shutter at one-thousandth of a second, I held the release in my right hand, and endeavoured by waving my hat in my left to induce the Hobby to take to the air.

She took not the slightest notice!

I then tried shouting-in addition to the hat waving. Still no notice ! Finally I broke off a beech bough, and shouting all the while, slashed about with it at any beech branches near by.

The only result of this effort was that the Hobby calmly watched the earthwards drifting of the leaves which I had broken off !

Since she evidently did not care to leave her charges-and as she seemed to treat my antics with a superior contempt-I desisted; and full of admiration for such a splendid little creature, took yet another photo of her brooding her young. At this moment-and it is strange how such things occur-the call of the male sounded from the trees on my right. Whereupon sheimmediately left the nest, and, silhouetted against the sky as she planed down to meet him, made the very effect I had been hoping for !

I had not reset the shutter!

But at least I had this time a most perfect view of the little male ; for he sat on a bare branch some $\mathbf{2 0}$ feet from me, with a small bird that he had already plucked in his talons. He really is the most perfect little thing. His head seems to be jet black, with of course the white cheeks and sides, his breast 


\section{THE SWIFTEST OF BRITISH HAWKS}

pure white splashed with longitudinal black markings, and his legs and the feathers of the thighs quite a bright red.

I could not make out what kind of bird he was holding, for since it was devoid of feathers, it was not easy to judge, but I should think that it was a warbler of some kind-certainly it was not a lark.

Soon the female fluttered to his side, and taking the bird from his talons with hers, returned to the nest and fed the young ones as before. After the meal was finished, and this time the family seemed satisfied, she lay on her side in the nest and puffed out her feathers very much as a chicken does when it dusts itself, and then collecting the young ones under her, she once more brooded them.

During the first week in August I climbed to the nest with the idea of inspecting the young Hobbies at close quarters, and went through a really remarkable - and quite unexpected-experience whilst doing so.

The female Hobby, as I commenced to ascend the tree, took perch upon her favourite dead branch, and as I had expected, began to scream heartily.

When my head was almost on a level with the nest, I looked across at her, silhouetted against the sky, and was quite surprised when she did not go off.

My surprise increased to amazement when I saw her start, with the definite action of a hawk flying some quarry, straight towards me!

For a few seconds I really thought she was going to 'bind to' my face ! But as she reached me she suddenly shot up with a ' fwt' of wings into the air straight overhead-leaving as a souvenir, three bleeding scratches across my forehead.

My companions down below gazed in astonishment as they saw her turn over and stoop again, only missing my head by a fraction of an inch as I ducked to avoid her-and again and again she threw up, turned, and came rushing by, sometimes hitting the mark, sometimes just missing me.

Once I held up my hand, which she hit with a resounding 'smack'-and for a moment I feared that I had done her some harm! But in a few moments she had regained her pitch and was pressing the attack in the most energetic manner.

What a grand little Falcon!

On August 20th the young Hobbies had left the nest, and were soaring at a vast height over the trees. I climbed up to the nest with the idea of discovering what creatures they were in the habit of taking. Amongst the débris in the nest were the wings of a May-bug, several cleanly-picked wings of larks, and the wing bones, with most of the primaries still intact, of a swift-and not the wings of a young swift, but of a mature bird.

When one watches a batch of swifts as they flash screaming around the houses in their enjoyment of the evening flight, one may well deliberate upon 
their extraordinary wing power, and their perfect control. What sort of a flight then must that be of a Hobby in pursuit of one of them ?

And who can say that the Hobby lacks courage, or is stupid?

I last saw the young Hobbies on August 23rd, and watched them for some time as they soared in huge circles at the usual elevation. At length one of the parents-the female, I should think, put in an appearance, and for some little time flew above them screaming. Soon I saw one of the young ones swing up to her in the air and take something from her talons. I have seen young Peregrines thus take food from the parents, but at nothing like the height at which the Hobbies were flying.

Having secured the meal the young Hobby half closed its wings, and dropped with terrific speed to the home wood, and into the home tree.

Doubtless the young Hobbies, like young Kestrels and Sparrow-hawks, continue to use the nest as a feeding-place for some time after they are able to fly. 


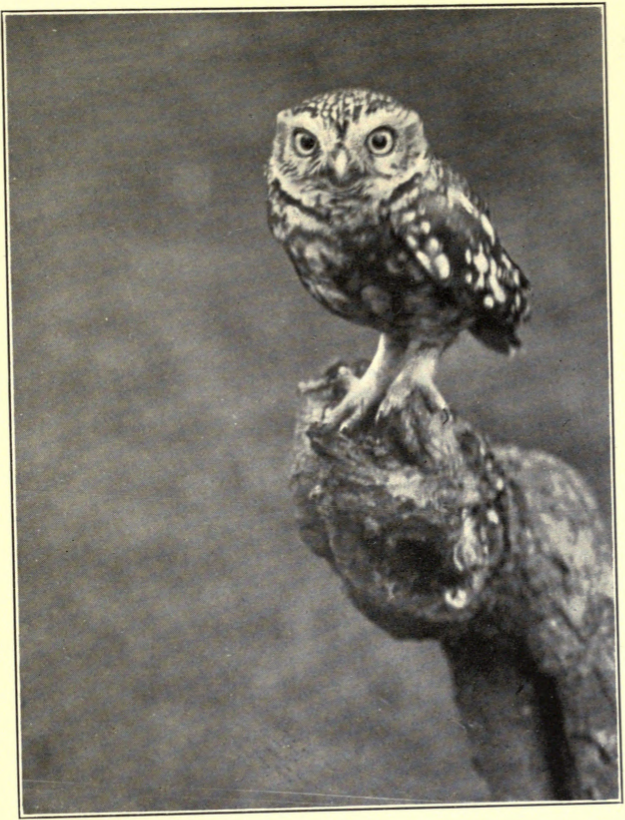

THE

LITTLE OWL

MATURF

AND IMMATURE

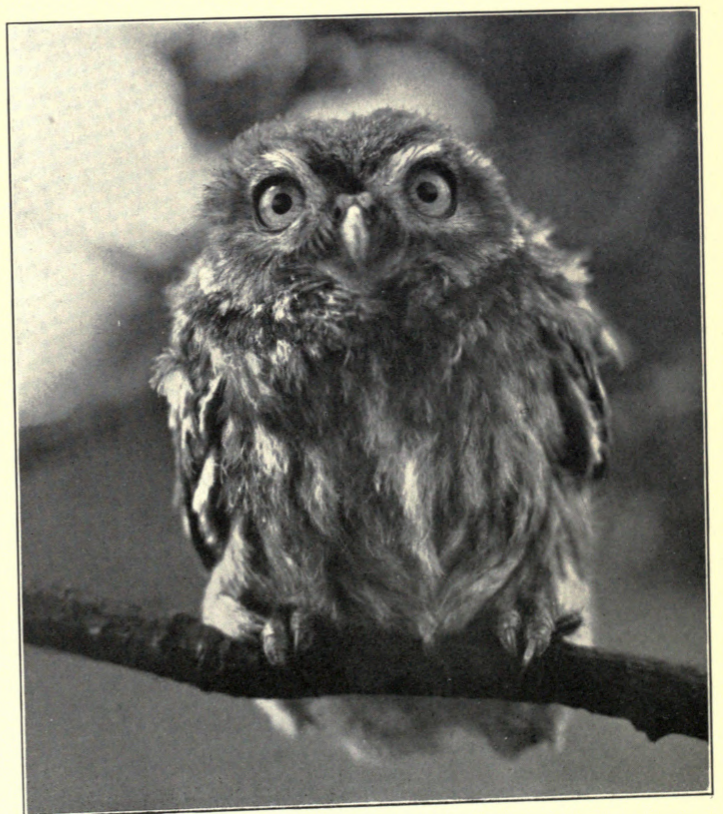





\section{CHAPTER VII}

\section{Two Brown Owls}

7 HERE are two species of Owls, which, in the district with which I am most familiar, come in for an overwhelming share of adverse criticism; two Owls which have somehow earned the reputation of living mainly upon creatures which man also covets-incidentally, the most undesirable reputation that any bird can acquire.

One of them is the wise-looking Tawny, or Wood Owl, and the other the Little Owl, and of the two the second, although hardly bigger than a thrush, has certainly the greater number of human enemies.

It is not so many years since one looked upon a Little Owl as being such a rarity that notices of its occurrence were published in various periodicals; and yet to-day we find it, in the South of England at least, by far the commonest of the owls, in spite of the fact that every man's hand-and gun-is raised against it.

The chief grudge against the Little Owl is that it has a taste for young partridges, and is particularly apt at picking them up. Then there are those who think its quaint cry a 'horrible screeching noise'; and last of all the fact that it is not a native of this country, seems sometimes to be resented; and the bird is looked upon as an 'undesirable alien,' with no real right to live here at all.

As for the much more cumbersome Tawny Owl-its fault seems to be confined to its habit of banging with its wings at night against the bars of the coop within which the young pheasants are sleeping under the protecting wings of a hen. Which manœuvre has the effect of bringing out all of the young pheasants at the double, when they are easily picked up by the watchful Owl-at least, this is what I am told!

My own experiences lead me to think that neither of these owls interferes to any extent with game; although I do not for a moment suggest that an odd young pheasant or partridge, which had lost touch with the main body, would not be picked up. Doubtless it would be, as long as it were not too strong for the Owl to tackle.

But in spite of the uproar of protest against his depredations, the Little 
Owl, at least, still contrives to hold his own, and the coveys of partridgesthis September of 1921-are as large and strong as I have ever seen them.

Even before the war this unpopular little creature, having been imported and liberated in the hope that it would become a permanent breeding species -was gradually becoming more and more firmly established, and during those unrestful days when the majority of gamekeepers had forsaken the woods for the trenches, and the gun for the rifle, the species had become so common that the former haunts of Barn Owl, Kestrel, and Stock Dove, were often tenanted by a pair of these weird little fellows.

When on the wing the Little Owl looks very much like a missel-thrush; particularly as he has the same straight undulating flight, and many an opportunity to bowl him over has been missed, for the reason that he was at first mistaken for the other bird. He is, in fact, comparatively seldom shot; neither is he often trapped, nor his nest easily discovered. Sometimes, of course, an odd bird is shot, or is caught, purely by accident, in one of the stoat or hedgehog traps which gamekeepers set in little wooden tunnels; on which occasions the Little Owl was doubtless on his way through the tunnel on the look-out for beetles.

During the evenings of March and April, he becomes very restless, and it is then that one hears most frequently his sharp yelping cry, sometimes uttered but once, and at others several times in quick succession.

But when the eggs have been laid, he, like so many others of his kind, observes a discreet silence, and it is not until the young are almost fledged that attention is likely to be drawn to the nesting-hole.

I have on many occasions looked into a Little Owl's nest, and on to the form of the brooding female, without her showing the least alarm. I have even lifted her off the eggs with my hand, and replaced her, without apparently disturbing her at all; in fact she has seemed to treat my intrusion with a complacent unconcern.

During the past summer I discovered a Little Owl's nest, which held two eggs, quite low down in an old elm stump; about a week later I again looked into the hole, and found that there were still only two eggs, though I had expected that there would be five or six.

Wondering if the nest was deserted, I reached into the hole, and found that the eggs were quite warm-and marvelled that the Little Owl should have been able to leave the tree without my seeing her. The following day I again inspected the nest; the Owl did not fly off, and as before, the eggs were warm.

This time I determined to satisfy myself that the Owl was not hiding within, and feeling in all the crevices and side-holes about the nest, ultimately discovered her squeezed into a small hole that ran upwards to another exit, which was not large enough to allow her to pass out. 
It is an instance which shows how difficult it would be to discover a Little Owl's nest by attempting to flush the bird.

When the young Little Owls are hatched-little fat creatures they are with chubby feet and red-rimmed eyes-their parents work hard to supply them with food; and, like the Buzzard, usually provide them with far more than they can possibly consume.

Even during the day the work is sometimes continued, and then each journey to and from the nest is attended by an excited throng of chaffinches, tits, missel-thrushes, blackbirds, and so forth; each one, it would seem, endeavouring to shout the others down, and the whole collection making enough noise to attract to the spot every gamekeeper within a radius of a mile.

One finds the Little Owl nesting in all kinds of queer places in these days : in hollow elm, oak, beech, or apple trees ; in holes in disused buildings, or even down rabbit earths, and yet the bird is not by any means easily photographed, for it seems invariably to nest in a dark hollow, which it is loth to leave, and also it has a most amazing habit-when its suspicions are aroused-of suddenly standing bolt upright, and then of squatting down just as suddenly on to its perch again.

As a rule the Little Owl's eggs-from four to six in number-are laid on the dry chips of wood and castings, which are usually at the bottom of the hole. The castings are generally quite small, and are composed of mouse fur, feathers, and numerous beetles' cases; although later in the season, when the young are feathering, much larger quarry is taken, for the nest is then littered with the remains of blackbirds, starlings, moles, and young rabbits.

I noticed, during the past season, when, by the way, there was an unusual number of young rabbits, that the Little Owls fed quite largely upon the smaller ones, and although they seem always to prefer a field mouse, or a mole, they have no hesitation in taking a small rabbit if the opportunity should occur.

It is a strange fact that each pair of owls invariably has a 'larder' quite close to the nest, in which supplies for the next day or so are stored. Sometimes such a 'larder' will be situated in a hole in the same tree, and some few feet from the actual nesting-hole. At others, it will be in a hole in another tree close by, or in a rabbit hole not far away: whilst in yet other instances it may be in the same hole as that in which the eggs are laid, but in a specially reserved corner.

The Little Owl, like the Tawny, or Long-eared, seems to trouble little about plucking the food as hawks do, although it often pulls out the long wing and tail feathers of winged quarry. As a rule the victims are swallowed in the manner which will cause least trouble, and any feathers that happen to be adhering to the selected mouthful are swallowed with the rest.

Amongst the victims comprising the larders I have discovered rats, mice, young rabbits, robins, sparrows, greenfinches, starlings, blackbirds, 
thrushes, missel thrushes, water voles (or water rats), various varieties of mice, frogs, and one bullfinch. I have not yet discovered the remains of any game bird!

I am indeed inclined to think that the Little Owl would not succeed in taking young game birds unless they were being reared under artificial conditions, when they would become so accustomed to the sight of the man who feeds them that they would be in the habit of running into the open to meet him, and in fact of spending the majority of their time upon grass that is not much longer than that of a normal tennis court. Under such conditions the Little Owl, or any other bird of prey, would not have the least difficulty in picking one of them up-nor scruples about returning for more.

But should a Little Owl attempt a raid upon a family of partridges in the wild state, his presence would almost certainly be detected by the old bird, who, by giving the alarm cry, would cause her youngsters to crouch motionless, or to vanish like lightning into the nearest cover.

If, however, the owl should come upon the family so suddenly as to seize one of them before they realized what is happening, the mother would without hesitation rush in to the rescue, and beat the miscreant off.

I am convinced of this because I have on several occasions seen a trained merlin attempt to ' bind' to a half-grown partridge, and have noticed with what determination the rest of the covey turn and set upon the aggressorinvariably sending him about his business.

Since the rearing-field is, to-day at least, a thing of the past, the Little Owl has little chance of dining off a brace of young partridges.

As to photography of the Little Owl, it is well for the enthusiast to remember that the birds will not, in all probability, be much on the move in the middle of the day; and, when all of the usual preliminaries have been duly adjusted, he had best make up his mind to endure some trying moments, and some monotonous hours. For the birds may not come near the place until evening, and the photographer may begin to wonder whether they have decided to discontinue the issue of rations during daylight hours. After all the owls can feed perfectly well in semi or complete darkness, and there is no reason why they should visit the nest simply because the photographer would like them to do so.

However, with luck, one of the owls, may unexpectedly put in an appearance, and her coming will be heralded by an excited clamour in which most of the small birds of the neighbourhood seem to join-missel thrushes and chaffinches perhaps predominate, but blackbirds, hedge-sparrows, tits, and so on, make a good second.

It is strange how any movement on the part of the owl will excite any small birds that may be mobbing it; and how quickly the commotion subsides if it should remain still for a while. Such a period of quiet may ensue that 


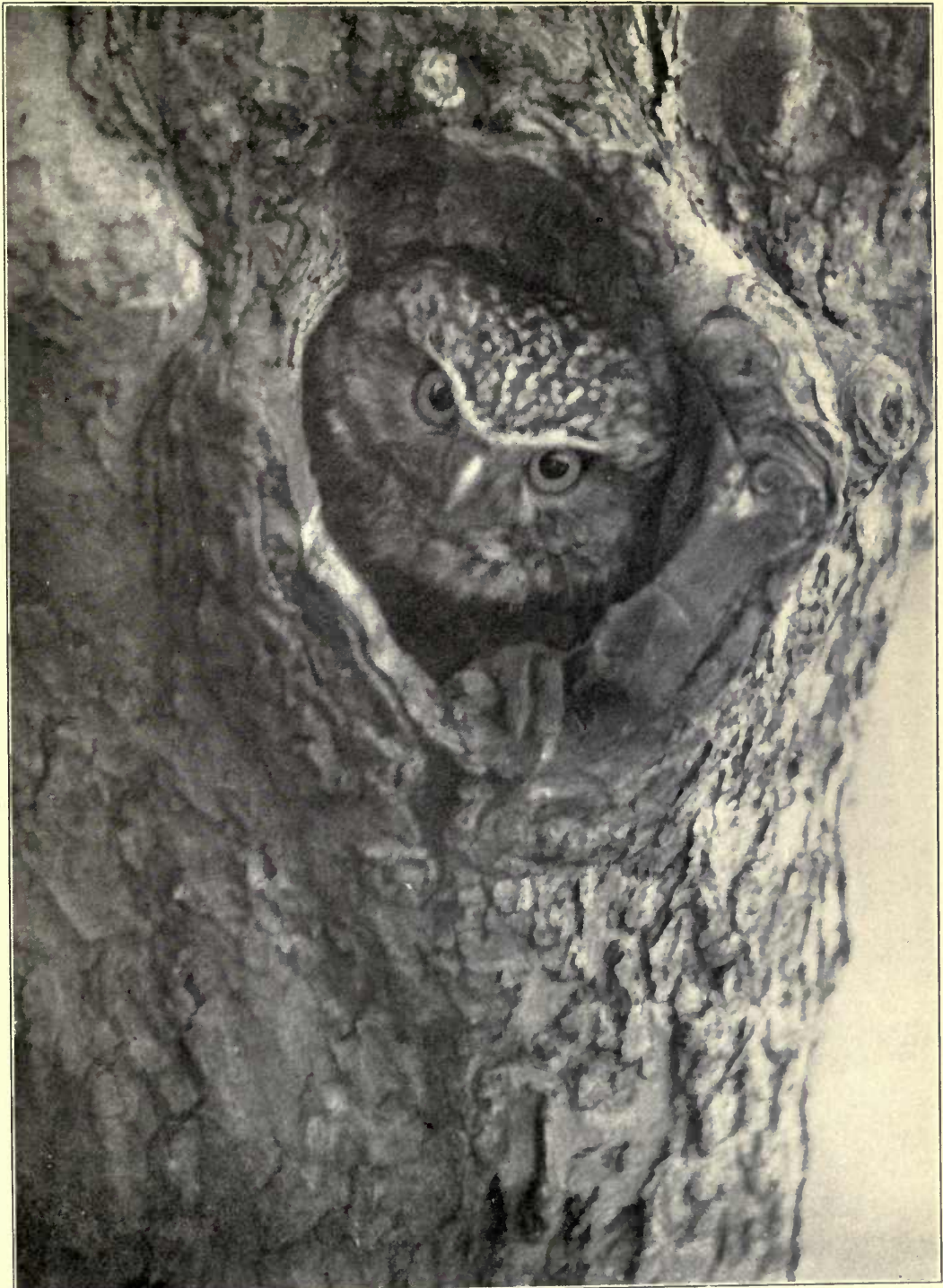



the photographer is tempted to ask himself whether, after all, the owl was not just paying a flying visit and may not have gone away again.

But suddenly, and with the suspicion of a 'flip' of her wings, she alights on a limb of her own tree, and not 10 feet from the nesting-hole. Hardly daring to move his head, the photographer gazes at her squat little form, with its great yellow eyes; and sees hanging from her talons the partially plucked body of a starling, or blackbird.

Evidently she is taking stock of the situation, for she peers around her on all sides, and turns her head, without the least difficulty, so that her beak is exactly over the centre of her back, and at length, having concluded that things are normal, she throws herself forward, with that queer action that is so typical of Little Owls, and, with hardly a pause, disappears head first into the nesting-hole.

This sudden and unexpected manner of entering the nest seems to be characteristic of the owls which nest in holes, and reminds me of a little incident which occurred years ago whilst we were exploring the ruins of a derelict cottage, in the chimney of which was a Barn Owl's nest.

We had never seen a Barn Owl at close quarters, and were, of course, very anxious to do so: but since this particular nest was some 6 feet from the top of the chimney, the chances of reaching one of the young ones seemed indeed remote.

The idea of removing one or two bricks close to the nest by working from one of the upstairs rooms of the cottage then occurred to us, and we accordingly improvised a chisel and hammer, and set to work. After some half an hour we had made a hole through to the inside of the chimney, and could see the young owls, now hissing and swaying about in a threatening way, standing on the edge of the nest facing us.

I suggested that if another brick were removed we could take out one of the young owls and examine it carefully, and my companion, being of a scientific turn of mind, put his face close to the hole, and looked through with the idea of seeing what had best be done.

At this moment, by some strange chance, one of the parent owls elected to return, and dropped feet first into the chimney with half-opened wings. The consequence was that the air, liberally mixed with soot and dust, rushed out, as from a bellows, into my companion's face and eyes !

I have during the past season seen a Tawny Owl enter her nest in exactly the same way, and have, in fact, endeavoured unsuccessfully to secure photographic records of her doing so.

Within a very short distance of where I am writing these lines stands the tree-or rather oak stump-in which the Tawny Owl laid her eggs and reared her young.

Before the eggs had hatched there was always something in the way of 
food for the sitting owl lying by the nest-a mole perhaps, or a couple of mice. The owl would sit very tightly, and usually declined to leave her nest until the face of the intruder loomed over the edge of her chimney-like home. And, if disturbed from her nest, she would usually return to it in about half an hour or so, but before actually 'falling' into the nest she invariably spent some time on a neighbouring oak-tree, gazing down on to the ground below her as though trying to discern the cause of her disturbance.

When she had finally convinced herself that there was no further need for alarm, she would stretch her wings, and float down towards the entrance to her nest, and backwatering, as it were, immediately above it, would poise herself for a fraction of a second, and then, with wings still open, but pointing upwards, would literally drop into it, her entrance causing a curious hollow 'plomp'-the sort of sound that a cushion makes when one drops it on a wood floor.

This particular owl was sitting on two eggs only : not by any means an unusual number, although the Tawny frequently lays four, or even five.

When the young owls eventually hatched, they seemed even more chubby than the young Little Owls; extraordinarily fat little creatures they were, covered with short white down, which reached to their pink toes. They also, when a few days old, had unhappy-looking red eyelids, which suggested that they were suffering from a severe cold in the head and gave them a rather unhealthy appearance.

As the young owls developed, the pile of food by their side grew larger ; field mice and rats formed the principal item, and so many of the latter were brought in that the gamekeeper of the place-who was happily a man of discrimination, and had no ill-feelings towards the owls-took, on several occasions, a handful of rats from the nest in order, as he put it, to ' encourage the old owls to hunt.'

This may be considered a unique attitude for a gamekeeper to adopt, but I know others who share his point of view.

As a rule the nest of a Tawny Owl-as in the case under discussion-is found to contain the bodies of rats, mice, and perhaps small rabbits; whilst, where the other three owls are concerned, the nests are almost invariably littered with the remains of feathered quarry, or the castings composed of their bones.

The Tawny Owl does not always nest in a hollow-sometimes it utilizes the disused nest of another bird as a home for its eggs and young, and it is not unusual to find it inhabiting an old magpie's nest, which, being constructed with a roof, affords the sitting owl a certain amount of overhead cover.

One of the illustrations shows a couple of red-eyed young Tawnies sleeping off the effects of a gorge on young rabbit, and inhabiting a magpie's nest, which was built at the top of an oak-tree-the latter half of the rabbit may be seen by their sides. 


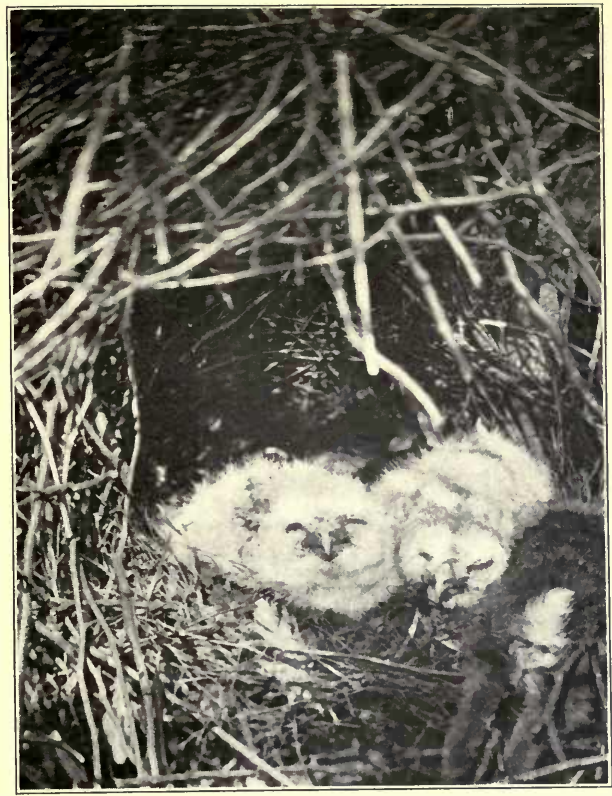

YOUNG TAWNY OWLS

IN A DISUSED

MAGPIE'S NEST

A TAWNY

LEAVING HER NESTING HOI.E

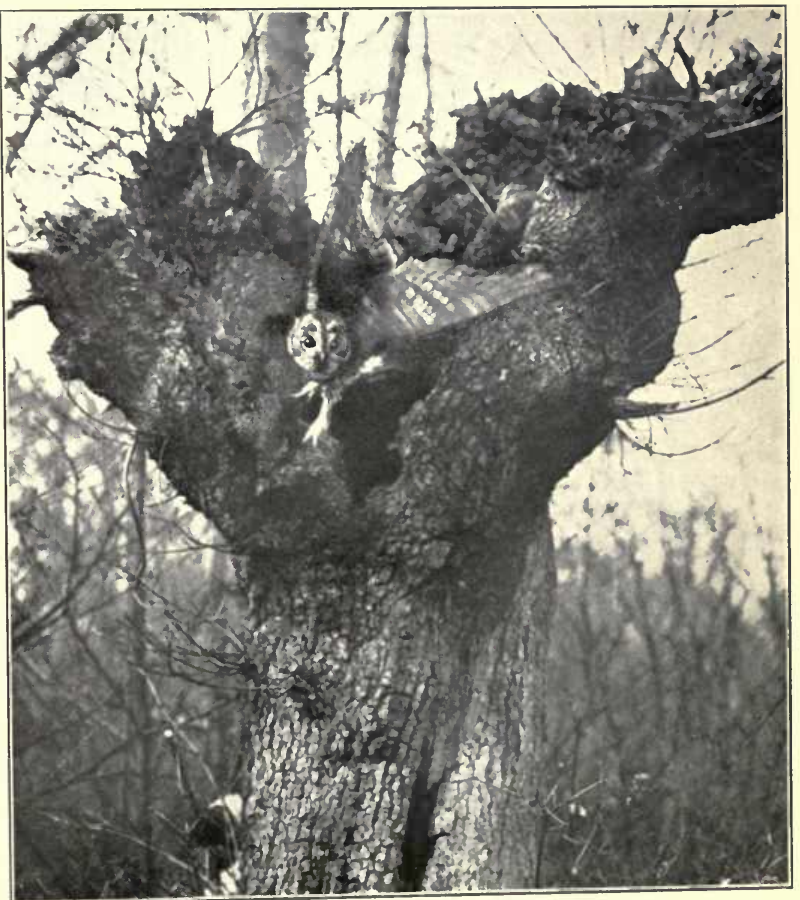



In another illustration is shown the young Tawny which we discovered in a magpie's nest whilst searching for the Buzzard. He had reached the stage when to remain at home in face of possible danger was irksome to him, for he elected to try his luck on the branches outside-he was, however, as yet unable to fly.

But, when they are available, the Tawny Owl would seem to prefer hollow trees in which to nest, and in such situations he is certainly safer from the gun. It is possible to blow a sitting bird to pieces when her nest is constructed of twigs and small branches, but one cannot shoot through a beech-tree, even if it should chance to be hollow.

That the Tawny Owl would seem to be gifted with a certain homing instinct is demonstrated by the following incident which occurred during my schooldays. I had an exceedingly tame Tawny, which, although it had complete liberty, would always come down on to the lawn in the evenings for its food.

Many a time-when darkness had set in-would I suddenly be reminded of the fact, by the incessant shriekings that went on outside, that I had not fed the Owl. And the moment that I went out on to the lawn the Owl would come down from some tree and dance round me with half-open wings, in its excitement at the prospect of food.

I remember once being presented with seven mice, which I gave to the Owl one after another. She swallowed them all, though the tail of the last hung from her beak in a despondent manner for some minutes after the body had disappeared!

However, food was not always easily produced, and I at last gave the Owl to a friend living some two or three miles away, who much admired it. He shut it in an aviary, and fed it carefully for some days, but, as might be supposed, the novelty of the thing wore off ; and I think he was rather pleased when one day his father offered him $5 s$. to let the Owl go. My friend agreed to the proposal, and fulfilled his part of the bargain-the Owl, when released, sailing majestically away over the trees. The next evening, however, it was back in its tree by my lawn, shrieking for food as energetically as ever!

Of the two Brown Owls that form the subject of this chapter, the lesser is, by comparison, much the stronger, and more courageous. When it is considered that it habitually tackles and kills such birds as missel thrushes, which are probably as heavy as itself, it may safely be said that it is able to do what none other of our owls can do.

Still, even a Little Owl is not strong enough to hold a full-grown partridge, and, for the reasons already set forth, it is extremely doubtful whether he would ever succeed in catching a young one. And it is highly improbable that a Tawny Owl would attempt to secure either. 



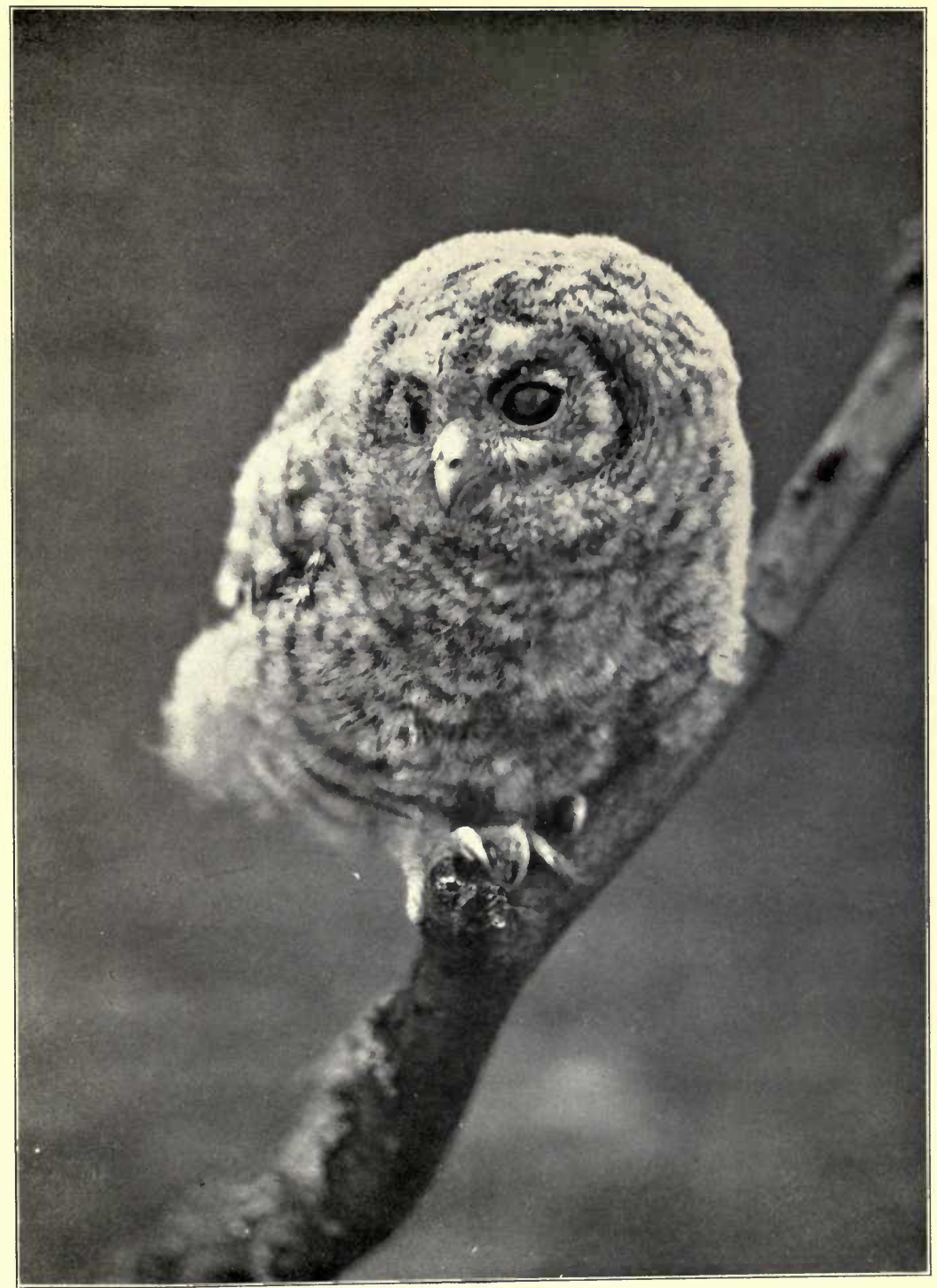

A YOUNG TAWNY 



\section{CHAPTER VIII}

\section{Denizens of a Beech Grove}
7 HE part of the country in which I chance to reside abounds in extremely fine beech trees; so fine indeed that the district has achieved fame on their account.

There is an unusual charm about a group of tall beeches, with their smooth green trunks, symmetrical shapes, and spreading foliage; a charm that is enhanced by the many interesting creatures which seek, in the breeding season, the seclusion of their shade.

It is generally in the month of May and June that the beech groves prove most attractive, for then the majority of the creatures which they harbour are hard at work rearing the new generation ; and one is pretty sure of finding, or seeing, something of peculiar interest.

In this particular locality there are certain birds which seem to have such a leaning towards beech trees, that they seldom make their homes anywhere else-although this peculiarity may be accounted for by the fact that there are such quantities of beeches; and that so many of them, by being more or less decayed, offer unusually comfortable nesting-sites.

A beech tree, unhappily for the aspiring ornithologist, is usually extremely difficult, and frequently impossible, to negotiate; for one cannot hope to climb up the bole of a tree which measures some $\mathbf{1 2}$ feet in circumference, and is quite devoid of branches for $\mathbf{5 0}$ feet or so! And the spiked affairs which are used by men for ascending telegraph poles are out of the question, as the bark is too soft to hold the spike, and the actual wood too hard to be penetrated. However, there are at least some amongst these inaccessible-looking trees which can be overcome, and on these we must concentrate.

The Tawny Owl and the Stock Dove-both of which love to nest in the hollow of a beech-are amongst the birds which begin their nest-building before winter has really left us; although nest building is really a too dignified term to use in the case of either of them; for the first generally lays its eggs on the dead wood at the bottom of the hollow, and the second, being a not much more gifted architect, collects only a few twigs and grass stems to serve as a nest. 
Both of these birds often commence to lay in the month of February, but since they are referred to in other chapters, we will not discuss them in detail here.

Probably the woodpeckers are the most attractive birds which inhabit the beech woods, and of these the Green Woodpecker is the commonest ; whilst the Greater Spotted is of rather less frequent occurrence, and the tiny Lesser Spotted the rarest. The Greater Spotted, however, being more frequently met with in the pine woods, has been dealt with in another chapter.

The Green Woodpecker, like its pied relations, excavates its nesting-home from the trunk or limb of a decaying tree, and does not, as is sometimes supposed, bore into sound wood.

There is one method by which it may be proved-even if the nesting-hole is out of reach-whether the woodpecker has been boring into sound or dead wood; and that is by examining the chips of wood which are thrown out and will be found at the foot of the tree-for the woodpecker does not carry away such chips, as it is sometimes supposed to. The male Green Woodpecker is distinguished from the female by having rather more crimson on the head, and a crimson medial streak running down the otherwise black 'moustaches.' Both of them take part in the excavation of their home.

They are really most amusing-looking birds, and quite deserve the local name of ' English parrot ' - as in fact they also do the ancient epithet of ' Yaffle,' for their ringing cry does somehow suggest the word.

As they climb, in a series of spasmodic jerks, up the smooth trunk of a beech tree, one is inclined to wonder how so heavy a bird can manage to do so with such ease. It is due to two facts: firstly, that their feet are especially arranged for the purpose of climbing-having two toes in front and two behind, which are armed with much curved and excessively sharp claws; and secondly that they, as it were, 'sit down' on their extraordinarily stiff tail feathers. The illustration of a Green Woodpecker at her nesting-hole perhaps shows more precisely than may be described, the manner in which the bird thus props itself up with its tail.

Although the Green Woodpecker usually utilizes a fresh nesting-hole annually, it so happens that this illustration shows a woodpecker at the entrance to a nesting-hole some years old.

The reason for this was that the woodpeckers had prepared a new hole some four feet lower down in the same tree, but that almost as they had finished their work, the place was appropriated by a pair of starlings-which birds not infrequently thus take advantage of the toils of the woodpecker.

A nesting-site which is at some considerable height from the ground is usually selected, and the difficulties of obtaining successful photographs are increased by the fact that the bark of the tree is too soft to hold the screws which (it is hoped) will keep the camera in position, and the actual wood so hard that it is difficult to persuade the screws to penetrate. In addition, the 
woodpecker is an unusually wary bird (as its face suggests), and in consequence of this fact, various cunning devices must be resorted to if satisfactory results are to be obtained.

This woodpecker has a habit, it seems, of intuitively suspecting the whereabouts of the observer, and having alighted against the far side of some branch close at hand, spends some time in popping its head round the corner-in order to carry out a short reconnaissance-and as suddenly withdrawing it.

However, its suspicions being at length partially allayed, it next flies to the home tree, usually settling so that the trunk comes between itself and the observer, and whence, once more, its head intermittently appears.

Presently it jumps sideways, and with a fluttering of its wings, climbs the tree until it is about three feet below the nesting-hole, when with a movement of the shoulders, neck, and head, which reminds one of an animal galloping, it commences the series of upward leaps, the click of its claws as they strike and hold to the bark being clearly audible.

On arrival at the entrance to the nest, the woodpecker, having taken a final look round, lowers her head and disappears inside to resume her duties of brooding the glossy pinkish-white eggs, which are laid on the chips of wood at the bottom of the hole.

When, later on, there are young in the nest, their presence may easily be determined by the uncanny and unique noise which issues, if the entrance be tapped. Evidently it is their cry of expectancy and pleasure and, imagining that their parent is about to give them food, they thus give vent to their feelings. The noise is really very much like the distant shouting of a crowd at a football match!

The parent woodpecker when visiting her young generally settles at a point some few feet below the nest-hole, and climbs upwards until it is reached; her arrival being loudly acclaimed by the wheezing family.

As the young develop, they learn to climb up the interior of the nesting cavity, which is some 9 inches to 12 inches deep, to look out on to the world, and incidentally to note the returning form of the food-laden parent: but since the entrance to the hole is only large enough to accommodate the head of one young woodpecker, they have, as it were, to take it in turns.

Thus, if the head of number one should be protruding when the parent returns with food, he will receive the whole consignment, and then retire into the depths amongst the rest of the family whilst number two takes his place. At this stage the cry of the young woodpeckers has also undergone considerable change, for it is now a sort of subdued but much more definite intermittent chattering.

Occasionally both old woodpeckers will arrive at the nest simultaneously, and one will then wait on one side until the other has delivered her consignment of food. 
Before giving the food to the young, the parent woodpecker first arranges it in her beak, and then, turning her head on one side, transfers it to that of the youngster with a curious quivering movement of the mandibles, the young receiving it in the same manner.

At length the day arrives when the young woodpeckers are sufficiently developed to leave the nest. This state of affairs does not imply that they are able to fly well-but that they can climb well, can sit comfortably on their spreading tails, and are able to take short flights from one branch to another.

Before venturing into the world, however, the young woodpeckers hesitate for some time at the entrance to their home. With head, neck and shoulders protruding, they await the coming of their parent, and utter for the first time the loud 'kewp' which one so frequently hears when the young Green Woodpeckers are spending their first days in the open.

This call is so much louder and more insistent than the hoarse whisperings of their youth, that one can only conjecture that it is instinctively developed in order to acquaint the parent birds with the new position of the young; for since they are continually on the move from tree to tree she would otherwiseone imagines-have considerable difficulty in locating them.

When the young woodpeckers do eventually take the plunge into the open, they seem to experience some difficulty in getting a firm foothold on the bark of the tree-which is, of course, very much smoother and harder than the accustomed inside of the nesting-hole. First one of them, having reached as far out as he possibly can without actually overbalancing, comes fluttering out, and clings on to the surface of the bark with shaky legs, and then, as it were, getting right side up, immediately commences the upward journey. After a while he comes to a halt and utters his ringing monosyllabic cry' Kewp.'

The rest of the family follow at shorter or longer periods; although owing to the fact that there is often considerable variety in size among the members of a woodpecker family, the last may not leave until a few days after the first.

The young Green Woodpeckers differ somewhat, as regards their plumage, from the mature birds; they have a spotted breast and throat, instead of the neater green of the old bird. Also their eyes are dark, and they lack the black, or black and red cheek stripes. They are, however, exceedingly beautiful birds.

Having left the nest, the young woodpeckers are fed for some time by their parents, but learn comparatively quickly to fend for themselves. The principal foods of the Green Woodpecker are ants and ants' eggs, and of them they consume millions. If one of the birds is seen to fly up from the ground, a careful search amongst the grass at about the spot from which it rose will generally reveal a quantity of small holes in the earth. These are made by 


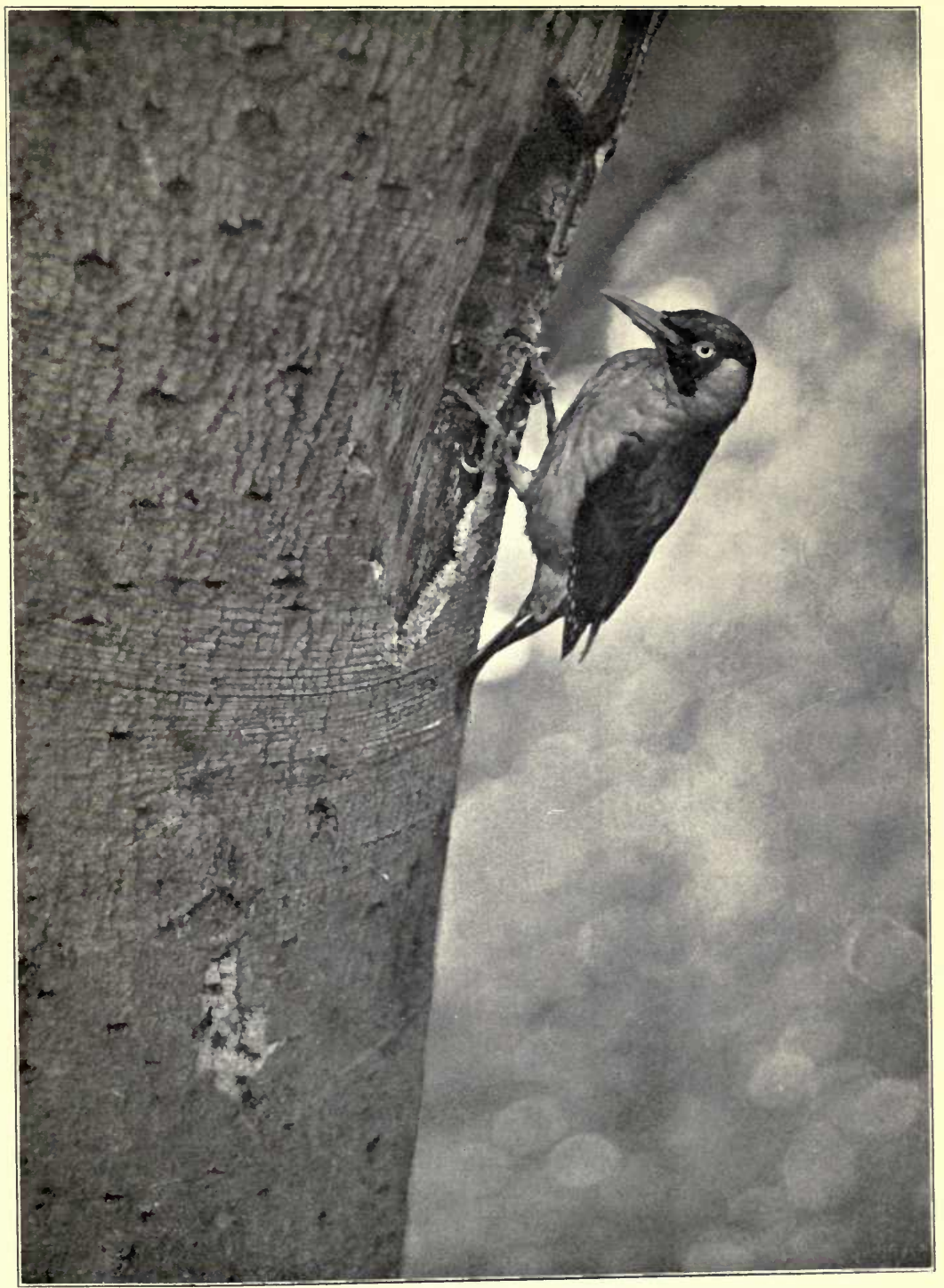

THE GRELN WOODPECKER

[Resting upon her stiff tail feathets.] 

the woodpecker's beak in his efforts to seek out the ants; which by the way he withdraws on the tip of the extensile tongue with which all woodpeckers are provided.

Such an extensile tongue may be protruded at will, and has at its tip a series of tiny barbs, together with a glutinous substance, which is secreted in glands at the sides of the woodpecker's jaws.

The Lesser Spotted Woodpecker-which often nests quite low down, and is comparatively common in certain districts, resembles his larger relation in many respects.

But there is one characteristic of this tiny bird in which it seems to differ from the Green Woodpecker, and that is in its habit of producing, in the early spring, a drumming or jarring noise. I have on several occasions been attracted by this extraordinary sound, and by careful stalking have eventually reached a spot from which a view of the cause of it could be obtained; and on almost every occasion have found it to be a Lesser Spotted Woodpecker. I have on very rare occasions discovered a Greater Spotted Woodpecker to be the cause, but it is almost invariably the Lesser.

The rapidity with which the 'Lesser Spot' strikes the selected piece of wood is almost incredible. One can accurately imitate the sound thus produced with an ordinary electric bell-only a cigar box should be substituted for the bell.

The sound is a call-note, and the woodpecker carefully tests the quality of various dead branches before selecting the one which, on being struck, emits the greatest resonance.

The actual call of the Lesser Spotted Woodpecker is a rapidly-repeated 'che-chee-chee,' a call very similar to the mating call of the Nuthatch, which latter bird also loves to make his home in the hole or crevice of a beech tree.

And although the Nuthatch, does not possess the stiff tail of the woodpecker, he is perfectly at home on the smooth bark of a beech, and is able to climb up or down, or sideways, or even upside down, without the least inconvenience. He is very little larger than a Lesser Spotted Woodpecker, and the entrance to his nesting-hole is almost identical in size with that of his pied relative.

It is very differently constructed, however, for in the first place, a Nuthatch does not excavate its own home, nor does it lay its eggs on the chips of wood at the bottom of the hole. What it does is to select a suitable nesting-hole, the entrance to which it closes in with mud so that there is ultimately only sufficient room for the bird to pass in and out. I have watched a pair of nuthatches thus closing up the selected hole, and have noticed that they bring the clay in the form of a little ball which is carried on the tip of the beak ; this they carefully poke into position, and go off in search of a further supply. On one occasion whilst I was watching this process of ' mudding up,' I noticed that the hen Nuthatch was doing all the work, the male bird contenting him- 
self with 'twit-twitting,' and constantly putting his head into the nestinghole, presumably delighted with the way things were going on. When dry, the mud-one might call it cement-is so hard that it is a difficult matter to break it.

The actual nest of the Nuthatch, when in the depths of a beech tree, is composed of small pieces of dry dead beech leaves, perhaps as many as would fill a large mug. Where the nest is in the neighbourhood of pines, it is made of the fine flakes which occur under the bark of such trees.

It is not unusual for a pair of nuthatches to choose as their nesting-place a hole large enough to easily admit one's open hand-so that a considerable amount of mud has to be placed in position before the entrance is sufficiently ' mudded up.'

In such a cavity, provided that it is at a sufficient height from the ground, and has a large enough interior, one may, in the early summer months, come upon a colony of Noctule Bats. I have personally never found these bats living in any other tree than a beech, although $I$ have at various times discovered many colonies; some of them consisting of as many as thirty or forty bats.

A general aversion to bats is common to many of us-and one has met ladies who really quite dread the idea of taking a walk on a summer evening in case a bat should elect to keep up its reputation by taking refuge in their hair !

But the bat, although not so shy as most wild creatures, possibly on account of the fact that it does not generally come into contact with mankind, is only too ready to beat a retreat if capture or death is threatened; and if one should be thus entangled it would be owing to an accident. Not infrequently on a dark windy night, a bat may pass by so closely that one's face or coat may be touched by its wing, and if, instead of the face or coat, the wing should happen to touch a woman's hair or hair net, the tiny claws would in all probability become entangled.

And then too, the bat, being such a grotesque, gargoyle-like creature, whose movements suggest evil, creeping things, is calculated to inspire a feeling of revulsion in the superstitious breast. But it should always be remembered that, in spite of its unfortunate appearance, it is blessed with the same emotions as the other more-attractive-looking creatures, and protects itself and its young with as much bravery and tenacity as the majority of them.

One may sometimes discover the retreat of a colony of Noctule Bats by chancing to walk under their tree on a summer evening, just as the bats are on the point of setting out for the evening flight. For at that time they become quite excited, and make a curious little chittering cry-very like the sound of two pennies being clinked together, and very much indeed like the incessant cries of young Spotted Woodpeckers-Greater or Lesser.

Presently a small brown head appears at the entrance to the 'den,' and a 
moment later a Noctule spreads its wings, drops for a few feet, and swings upwards and away into the evening air. Soon another follows, and another, and another, each one allowing himself to drop for several feet-and thus gain impetus-before winging his way through the trees.

It is quite an uncanny experience to look into a bat's den and see the forms of the bats hanging head downwards from the roof, or moving slowly and silently about the walls of their home. The scent of such a den is extremely unpleasant-a queer sickly medicinal smell that is, as far as I know, not to be encountered elsewhere.

When the bats realize that an enemy is at their door, their movements become more rapid, whilst an atmosphere of anxiety comes over them. First one and then another will prepare to make a dash for freedom, only to scuttle back into the darkness if the intruder should make any sudden movement. Presently a little wrinkled bull-dog face will appear at the threshold-its thick upper lip quivering, its tiny deep-set eyes shining in terror; then like a flash it starts back, its sharp little teeth bared, its head well back between the shoulders. Attempt to touch it, and you will most assuredly be bittenalthough, since the bat's teeth are quite short, no more serious damage will be done than the loss of a little blood entails.

Noctule Bats certainly look evil little creatures; but after all they are not responsible for their forms or faces, and the female Noctule is a most devoted parent.

When the single young one is first born it clings to the underside of its mother's body with its tiny claws, and to her breast with its as yet toothless gums, and in this manner it is carried by the mother when she takes her nocturnal flights. It runs no risk of becoming detached, for it clings on with the most extraordinary tenacity, and in fact can only be pulled off with difficulty. These newly-born little bats are even more gargoyle-like than their parents, for they are quite hairless and are covered with a pinkish, wrinkled skin. When they are sufficiently developed they are left behind when their mothers go out for the evening hunt. By this time they are covered with a very short mousecoloured fur, unlike their parent's, whose coat is a rich chestnut colour. I have looked into a bat's den on a summer evening, when the females had left for the night, and seen some two or three dozen young bats, as yet unable to fly, squirming and writhing within!

During my varied experiences of these bats I have not yet discovered a colony in which both sexes were present-that is to say, the colonies were invariably composed entirely of males or entirely of females. One day I may be lucky enough to discover a mixed colony.

It is a common belief that the bat, if placed upon flat ground, is, on account of the shortness of its legs, unable to fly. I well remember, years ago, taking two Noctule Bats home with me to see if this was so. One of them I placed 
on the tennis lawn, where it remained for a moment, and then raising its body on the tips of its wings, flapped vigorously and eventually got up into the air. For a few moments it circled round like a homing pigeon liberated from a basket, and then, getting its bearings, went off in a bee-line for the beech wood from which I had taken it.

I was about to test the other, which I had placed in my pocket, when it managed to escape, and having circled round some half-dozen times, followed its relative towards the familiar trees. 


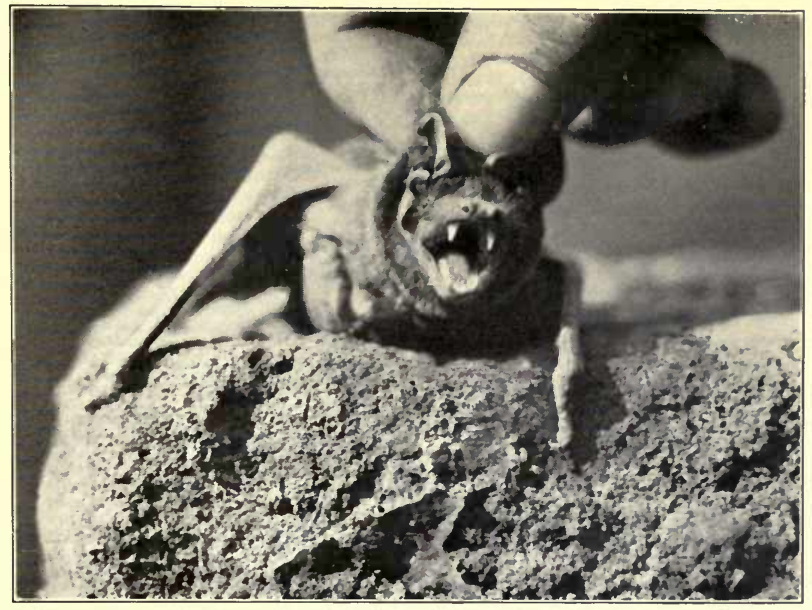

THE

NOCTULE:S

TEETH

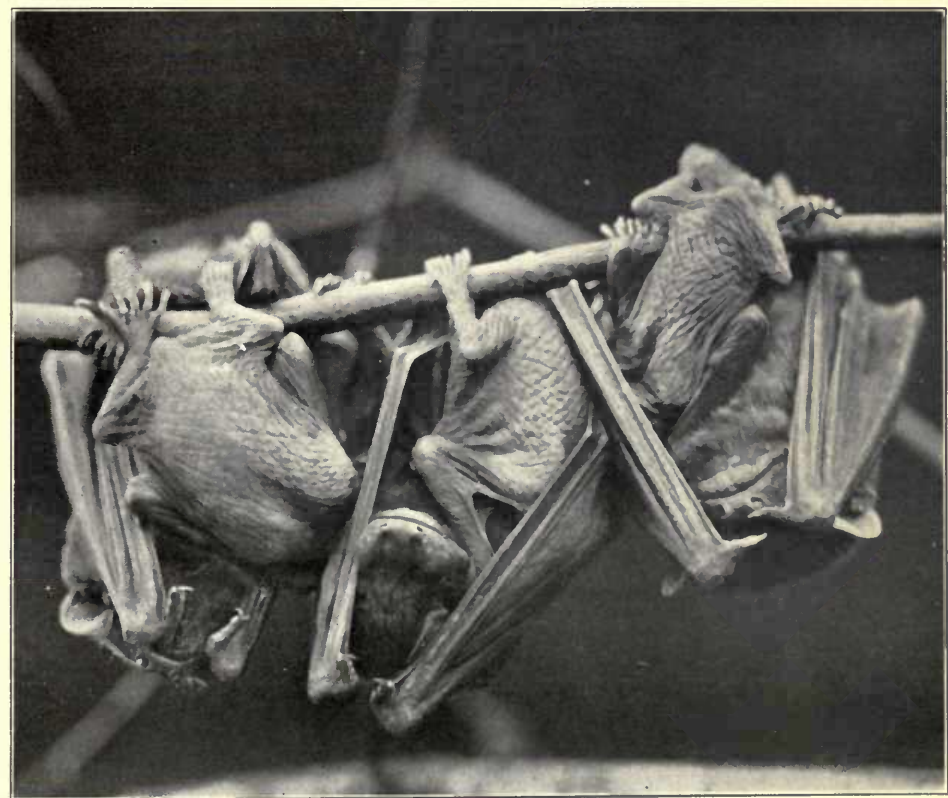

THREE FEMALE NOCTULES AND THEIR YOUNG 



\section{CHAPTER IX}

\section{About the Kestrel}

7 He Kestrel, or Wind-hover, is probably the one British hawk with which the people of this country generally are really acquainted; for it is so widely distributed, and is so conspicuous in its unique habit of hanging motionless in the air, as to have attracted the attention of almost every one.

In fact, in many districts, the only conditions under which the inhabitants have ever seen a hawk is when it is thus 'hovering' over the fields; and so, merely putting it down as 'a hawk,' they have come to the conclusion that it is characteristic of all hawks to hover.

This, however, is not the case, and although the Buzzard may hover for a few seconds over a hedge where a rabbit is hiding; or a Merlin may do so in like manner over the spot where her quarry has 'put in '; the Kestrel is the only British hawk which habitually hovers whilst on the look-out for its prey.

For the Kestrel, known in the ancient days as the 'Knaves' hawk,' is indeed a poor flier, and relies upon the impetus which it derives from dropping from a height to enable it to catch such fast flying birds as starlings, or meadow pipits.

As a general rule, the Kestrel does not trouble about pursuing such elusive quarry, and subsists largely upon beetles, frogs, earthworms, and the like; although when its eggs are hatched, and there is an incessantly hungry family to feed, it must needs exert itself to secure more substantial items, and it is then that it tackles the more dignified fowl.

Such a variety of views have at various times been expressed as to the amount of 'good' or ' harm' Kestrels do to mankind that it would be rather difficult, without some first-hand knowledge of the bird, to form any definite opinion as to its manner and means of subsistence.

There are those who affirm that it feeds almost entirely on beetles, grasshoppers, or the remains of any dead creatures that it may find; and on the other hand there are others who maintain that its diet consists of mice, voles, and occasionally a young bird of some small species.

Then, of course, the gamekeepers-or many of them - tell us that the bird 
is a poacher of the worst possible type, who troubles not about beetles, or mice, when the young pheasants are about; and whose proper place is among the stoats, hedgehogs, and jays on the 'scrag-pole.'

It is a mistake to suppose that the Kestrel feeds exclusively upon any of these delicacies. One has to consider that some of them are not available at all times of the year; and that the Kestrel is harder pressed for food at some seasons than at others.

Actually, it feeds more or less upon them all, and though I have often argued with gamckeepers to try to persuade them not to shoot the Kestrel, I know within my heart that the little hawk does occasionally take young pheasants -when an easy chance presents itself-just as he does occasionally feed on dead rabbit, or earthworms.

There can be no doubt, however, that the number of game birds destroyed under natural conditions, by Kestrels, is extremely small, and quite insignificant when compared with the vast quantities of beetles, mice, etc., that the bird consumes. For I am certain that, if young pheasants were reared in the wild state, and under the care of a protecting mother, there would be practically no danger of any of them falling a victim to a Kestrel-for precisely the same reason as in the case of the Little Owl.

And the argument that applies to the Little Owl applies equally to the Kestrel. There are more, and stronger, partridges this year than there have been for many seasons; there are also-perhaps as the result of the warmore Kestrels.

I have in mind a particular district where, owing to the fact that the owner of the place is a keen ornithologist, Kestrels are not interfered with. During the past summer I chanced to find no less than five Kestrel families in a quite small area. All of them got safely away, and yet the number of partridges in the vicinity to-day is really prodigious, and on September 17 of this year twelve guns killed no less than eighty-three brace.

Still, in spite of sustained arguments, the war against the hawk tribe is carried sternly on. Many Kestrels are shot annually in the breeding season, for there is nothing easier than to creep to the foot of the tree where the Kestrel has her home, and have a couple of barrels at her as she goes away. And after all, if a hit is not scored, it does not matter much, for the little hawk is so solicitous for her eggs or young that she is certain to return to them pretty soon, and then one barrel ought to do the business if she should pitch on to a bare branch with no intervening leaves.

I really think that a number of gamekeepers class Merlins, Kestrels, and Sparrow Hawks under the heading of 'Hawks,' and do not trouble to differentiate-even if able to do so-between them.

The Kestrel-like the Hobby and the Merlin-does not build a home for itself, but either lays its eggs in a hollow, or appropriates the nest of some 
other bird, usually that of a crow or magpie, and often does so within a few days of the evacuation of the rightful owner; as, for instance, when $I$ found a crow's nest containing five Kestrel's eggs and one crow's egg-the female crow having been shot as she left the nest some two weeks before. The Kestrel was, of course, sitting on the six eggs, though I never knew if the young crow hatched under the strange foster-parent.

I also remember a rookery in which a pair of Kestrels had taken over one of the rooks' nests, in spite of the fact that the young rooks had flown only some week or ten days previously.

And a pair of Kestrels will often fight for a nest which has happened to take their fancy and which the rightful owner is loth to relinquish.

I have watched a pair of Kestrels, who had designs upon a Carrion Crow's nest that was undergoing construction, endeavour, by repeatedly stooping at the crows, to drive them out of the neighbourhood, so that they might take possession of the nest.

The crows, however, being strong, courageous birds, were not easily intimidated, and gave the Kestrels as good as they received; although at last, wearying of so much hard flying, they decided to decamp, and left the little hawks victors of the situation, and free to commence the business of rearing a family.

Kestrels, like the other hawks, usually return to the same districts annually to nest, and lay from three to six very beautiful reddish-coloured eggs. While the female is sitting the male sometimes takes perch near the nest, and utters from time to time a long-drawn plaintive cry, which, perhaps, is his best attempt at a song.

I have known of an instance in which the male Kestrel seemed to do all the brooding whilst eggs were in the nest; in any case I took several photos-one of which is reproduced here-and each of them showed the male bird on the nest.

There is a very considerable difference in colour between the female and male Kestrel ; for whereas the former is of a uniform rusty brown colour, covered with markings of a darker brown, and has a tail that is laterally barred with black and greyish bands, the latter is of a much more reddish colour, with a slatey-blue tail having a single broad black band across the end. So there is no mistaking a male Kestrel, even in a photograph.

Whilst attempting to obtain cinematograph records of the Kestrels at home, I had perhaps, unusual opportunities of watching the birds at really close quarters, for my observation post was but 8 feet away from the nest; and, since whenever I tried for photographs I generally stopped in it all day, I could not very well do otherwise than witness some interesting and amusing incidents.

Of course various preliminaries in the way of fixing the sacking, of arranging the cinema camera platform, of lashing in position a small branch to act as a 
seat, all had to be overcome, and the tout ensemble camouflaged before it could be occupied. I remember that the one particular difficulty that arose was due to the fact that I had arranged to have the camera on the left-hand side of the tree, but had not allowed for the extra space that the handle would require-for when $I$ ultimately fixed the camera in position $I$ found that it would be impossible to turn this handle without moving the whole camera-or cutting off the top of the tree!

However, it seems that such difficulties are more or less bound to occur. One can only learn by experience, and try, by looking ahead, to foresee possible pitfalls.

When I first retired into the observation post the young Kestrels were only about ten or twelve days old-although even at this age they were sufficiently advanced to crouch instinctively on the nest until they felt that danger had passed. Soon, however, they began to rise up and take an interest in life; all four of them setting to work to preen their growing feathers, which were just appearing through the down, or pecking thoughtfully at the dried-up bones of small birds on the floor of the nest.

Then one of them-tired it seemed of this life of lethargy-would stand on the extreme edge of the nest, and facing the other three, would proceed to exercise his wings in the most vigorous manner-his stumpy half-grown tail working up and down like the parasol of a tight-rope walker, as he tried to maintain his balance.

Presently I heard the long-drawn cry of what I imagined to be the male returning with food for the family; and through a hole in the side of the observation post I caught sight of him-followed by the female, who was now also screaming - as he planed down towards an elm-tree away to the right.

A few moments later the young Kestrels showed evident signs of expectancy, for, with partially spread wings, and uttering the little cry that they make when feeding time is at hand, they gazed intently into the branches above them; and without further warning, the female Kestrel, holding in her beak the body of a small bird which had been pretty thoroughly plucked, dropped suddenly on to the side of the nest.

Then transferring the prey from her beak to her foot, and holding it down with the talons of the first toe, she proceeded to tear it to pieces with her beak. When a small, and conveniently shaped, piece was detached, she held it out in the tip of her beak to one of the young ones, who immediately seized and swallowed it; in fact the various members of the family seemed to be so anxious to secure a full share that they often pecked small pieces from the body of the victim as it lay under their parent's feet. If rather too large a piece was torn off, the mother would either break it up and distribute it, or swallow it herself. She did not, as did the Hobby, disgorge any food for the youngsters-doubtless because they had passed the stage when they should be fed in that way. 


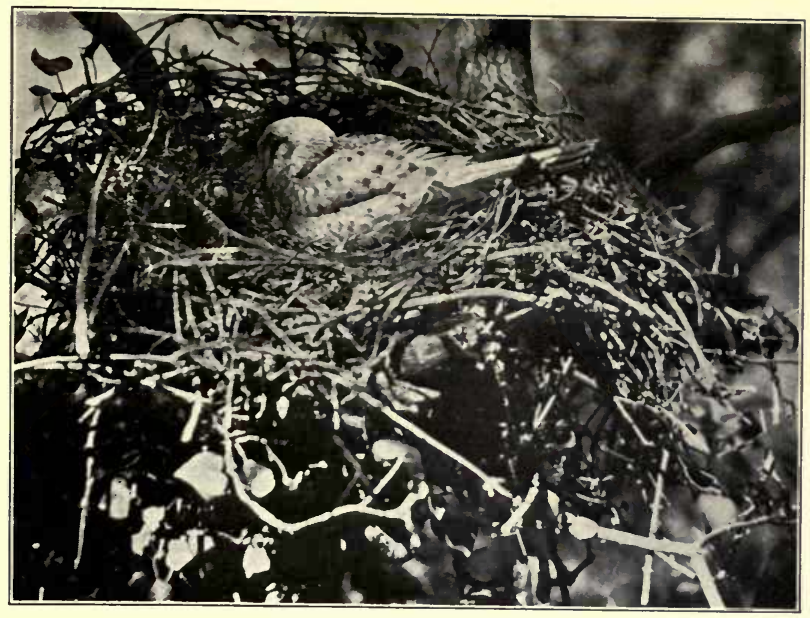

THE

MALE KESTREL

BROODING

NEWLY HATCHED YOUNG KESTRELS

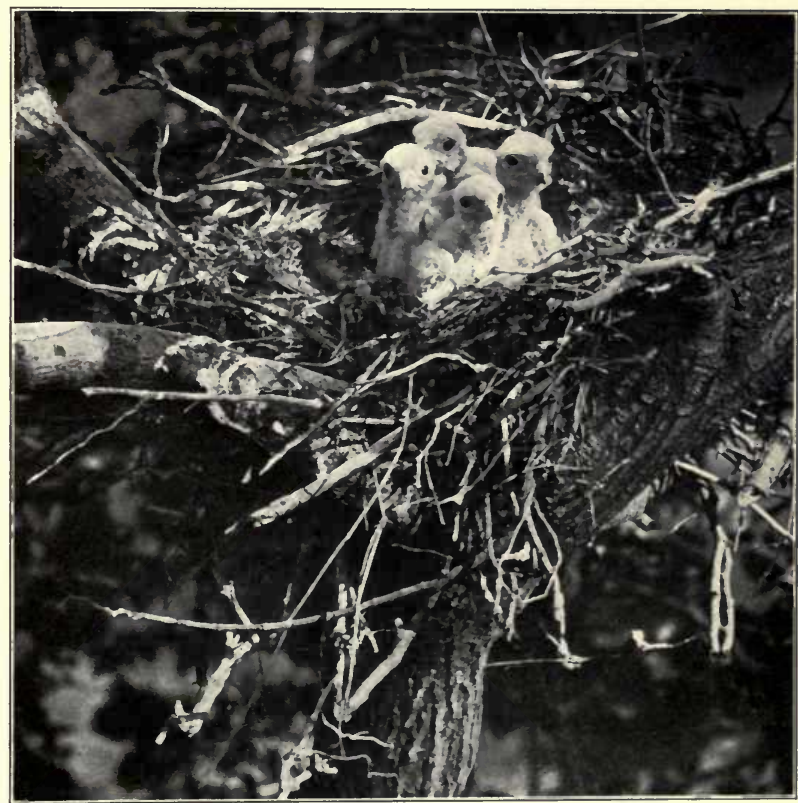



One of the accompanying illustrations shows a female Kestrel at the moment of her arrival at the nest-which contains quite small young ones-with a mature meadow pipit in her beak. It was once criticised as being a probable 'fake,' because the critic was under the impression that Kestrels invariably feed their young by the process of regurgitation-whereas actually they only sometimes do so.

But there is another point of interest about this photograph, which is this : How can so slow-flying a bird as a Kestrel catch such a clever flier as a mature meadow pipit ? It certainly could not do so in fair flight, and we can only presume that the Kestrel, whilst hovering overhead, chanced to spy the pipit amongst the grass, and without any unnecessary warning, pounced on it.

When our Kestrel had distributed all of the food, she stayed with her young for a while, and then, apparently satisfied with their appearance, flew off to a favourite perch in a neighbouring tree.

Within less than an hour the male again uttered his call note, and as before the female soon afterwards returned to the nest-this time with an immature lark in her beak. This lark was in fact so young that it is doubtful whether it would have been able even to crawl, and the only flight feathers it had consisted of little quills with the suggestion of webbing at their tips.

So the male Kestrel is evidently not above settling by the nest of some ground-building bird, which he has espied from aloft, and proceeding to drag out the unfortunate occupants. I am of the opinion that one can judge pretty accurately the mentality of a bird by studying its face; just as one may ' size up ' a human being. And of all the hawks I think that the Kestrel, judged by its expression, is the one that would do such an undignified thing as to drag half-fledged birds from the nest! One certainly cannot imagine the ferocious wild-eyed Sparrow Hark doing anything of the kind; nor indeed the keen, bright-eyed little Merlin.

But to return to the nest. I next tried for some cinema records about a week later, and was quite surprised to see how much the young Kestrels had developed. They appeared not to be much bigger, but the way in which their speckled feathers were coming through the down imparted to them a very much more 'grown-up' appearance.

Also they were much more upset at the shock of seeing me than on the previous week, for they lined up facing me, on the farther side of the nest, and with raised wings and open beaks prepared to fight to the last. During such a demonstration, young hawks, be they Merlins, Sparrow Hawks, Hobbies, or Kestrels, make a curious little gasping sound, which suggests that they are so frightened that they cannot get their breath properly.

However, when all was quiet, they presently regained their composure, and soon resumed their pastimes of preening, exercising their wings, and clutching with their talons at imaginary victims. It is interesting to note how young 
animals, or birds, particularly those kinds which prey upon other creatures, instinctively practise in their youth the means by which they will ultimately procure their food. Kittens devote an extraordinary amount of time to the business of stalking one another round the table legs ; puppies exhaust themselves by digging holes, and chewing bedroom slippers ; and the young Kestrels spend hours, on the extremely limited space which the nest affords, in snatching with lightning foot-stroke at any pieces of wood, bone, or other débris that may chance to take their fancy.

On this occasion I had arranged a small hole in the canvas of the observation post quite close to my head, and by placing my eye closer to it could get a very good view of the country below and of the distance away over the marshes, where I noticed the male Kestrel generally did his hunting.

As it turned out, this proved to be a useful move, for during the day I heard the call of the approaching male, and placing my eye to the peep hole witnessed a pretty incident.

He was returning from the direction of the marshes, and even from that distance, probably some 200 yards away, I thought I could make out a little lump beneath him, which I took to be the body of some victim that he was bringing to the young. When he had got to within about 80 yards of the tree, I saw the female fly from a bare branch on which she was sitting, and swing up to him in the air. For a moment the two forms seemed locked together, and then they swung apart, the one to return marshwards, and the other, now with the prey in her talons, to come immediately on to the nest.

She did not, however, stay to distribute the meal, apparently for the reason that she considered that the young ones ought by this time to know how to help themselves-an opinion that to some extent was justified, for one of the young hawks lost no time in falling to upon it, and by turning his back upon any one of the others that approached too closely and, as it were, forming a tent out of his half-spread wings and tail, was able to enjoy his meal without interruption. In fact the rest of the family seemed almost immediately to give up the idea of attempting to share in the spoil, and resignedly carried on with the work of preening and wing-stretching. It would almost seem that, at this age, the young Kestrels utterly lacked any idea of initiative, or persistence, for only the individual who had first seized the food showed any signs of keenness for it-the remainder merely trying in a half-hearted way for a share, and then standing on the edge of the nest listlessly gazing into space, until it occurred to them to do something more useful.

Later in the day the male Kestrel came in with a field mouse in his talons. This the female took from him as before, and brought to the nest, where it was quickly devoured by the youngster that was lucky enough to grab it in the first place.

I particularly noticed that this mouse had not been plucked, and it is 
interesting to note that the Buzzard should so carefully prepare young rabbits, whilst the Kestrel does not trouble about plucking anything but feathered quarry.

Instead of returning to the marshes as before, the male Kestrel came and perched on a branch just over the nest a few yards from where I was sittingand an exceedingly beautiful bird he was, with his slate-blue head, almost plumcoloured back, and blue-grey tail. He was very little smaller than the female, smarter in bearing, and perhaps closer-feathered.

Some six days later I again visited the young Kestrels, and again they had undergone a metamorphosis. Now the woolly coats of their youth were exchanged for the sleek, perfectly fitting feathers that were coming down so rapidly, whilst they had also acquired the fierce, eager expressions of the old birds.

The only noticeably youthful characteristic about them now was the little white downy tuft that still adhered to the top of each of their heads, and which imparted to them an almost judicial appearance.

And their fierce expressions did not in any way belie their subsequent actions, for when the call of the male heralded a fresh supply of food, the young hawks developed such a state of noisy excitement as.would suggest that they experienced difficulty in containing themselves in their efforts to be first at the psychological moment.

And, as before, the female suddenly alighted on the nest; and left with them the partially plucked body of a young thrush. But now no lethargy, no lack of initiative is apparent among the eager family. Useless is it for the one who has secured the prize to try to shield it from the rest of the family. Now it is every man for himself, and the devil take the hindmost.

First one and then another drags the body of the unhappy thrush from the clutches of brothers and sisters, whilst mouthfuls are snatched by those who happen to see a convenient portion protruding from under quivering tail or wing.

Eventually the whole family are tightly packed on the meal, each one it seems endeavouring to eat his fill before the others have finished everything up.

In the end there proved to be more than they could manage; although even then the one who had got possession of the remains seemed loth to let them go, and prepared to drag them after him as he walked backwards round the nest.

The flight feathers of the young hawks were now so far developed that when they exercised their wings they were able to raise themselves from the nest; in fact, one of them during an unusually strenuous bout of wing-testing held firmly to the side of the nest with his feet, so that he should not be carried away by his enthusiasm.

I am inclined to think that when I next witnessed the bringing of food to 
the nest, the victim had been secured by the female Kestrel-just as when young Sparrow Hawks are almost ready to fly the female begins to hunt and capture quarry which the tiny male, except under abnormal circumstances, could not hope to tackle.

For I saw her returning from the marshes, and, as she drew nearer, noticed that there was something hanging from her talons. This time she came, without the least hesitation, straight on to the nest, and left with the family the body-minus its head-of a partially plucked starling.

There is but little difference in size between a male and a female Kestrel, so it does not follow that the male would be unable to tackle so strong a bird as a starling, but he had certainly in the past contented himself, as far as my experience went, with lesser fry.

At this stage in their upbringing the young hawks, with all of their principal feathers in the blood, require an amazing amount of food, and it may be that the male is unable to obtain a sufficient quantity.

At about this time I noticed too that the parent hawks seemed unusually anxious as to the safety of their young, and on their behalf became possessed of remarkable courage-just as the Hobby, when her young were about to fly, became so bold.

On many occasions I watched for several minutes the graceful evolutions of the female as she strove to drive a Carrion Crow from the neighbourhood of her nest. Screaming angrily, she would mount up into the sky, and descend with very creditable force at the crow, throwing up at the instant that she reached him, but never, it seemed, actually striking him with her talons. The crow, noisily voicing his remonstrance, meanwhile spent his time in avoiding the stoops, and in endeavouring to mount up so high as to have the Kestrel at a disadvantage.

Ultimately he succeeded, and in turn began to stoop at the elusive Kestrel -without much success.

As the flight-if such harrying of one another may be called a 'flight'progressed, the crow's mate, perhaps seeing her companion in difficulties, joined in the fray, and still the Kestrel, with two opponents to deal with instead of one, shifted from their attacks with the utmost ease. Doubtless the crows also had a family in the vicinity, for otherwise they would hardly have regarded the presence of the Kestrel so seriously.

It was not unusual to see the Kestrels dash out from their trees and attack a passing, and quite innocent Heron, which, uttering the most undignified squawks of terror, would twist and dive to avoid their stoops.

It is strange how the fact of being attacked-no matter by whom-seems to demoralize most birds. One is often inclined to wonder why, for instance, a London pigeon should retire in such fearful haste from the sparrow which is chasing it ! 


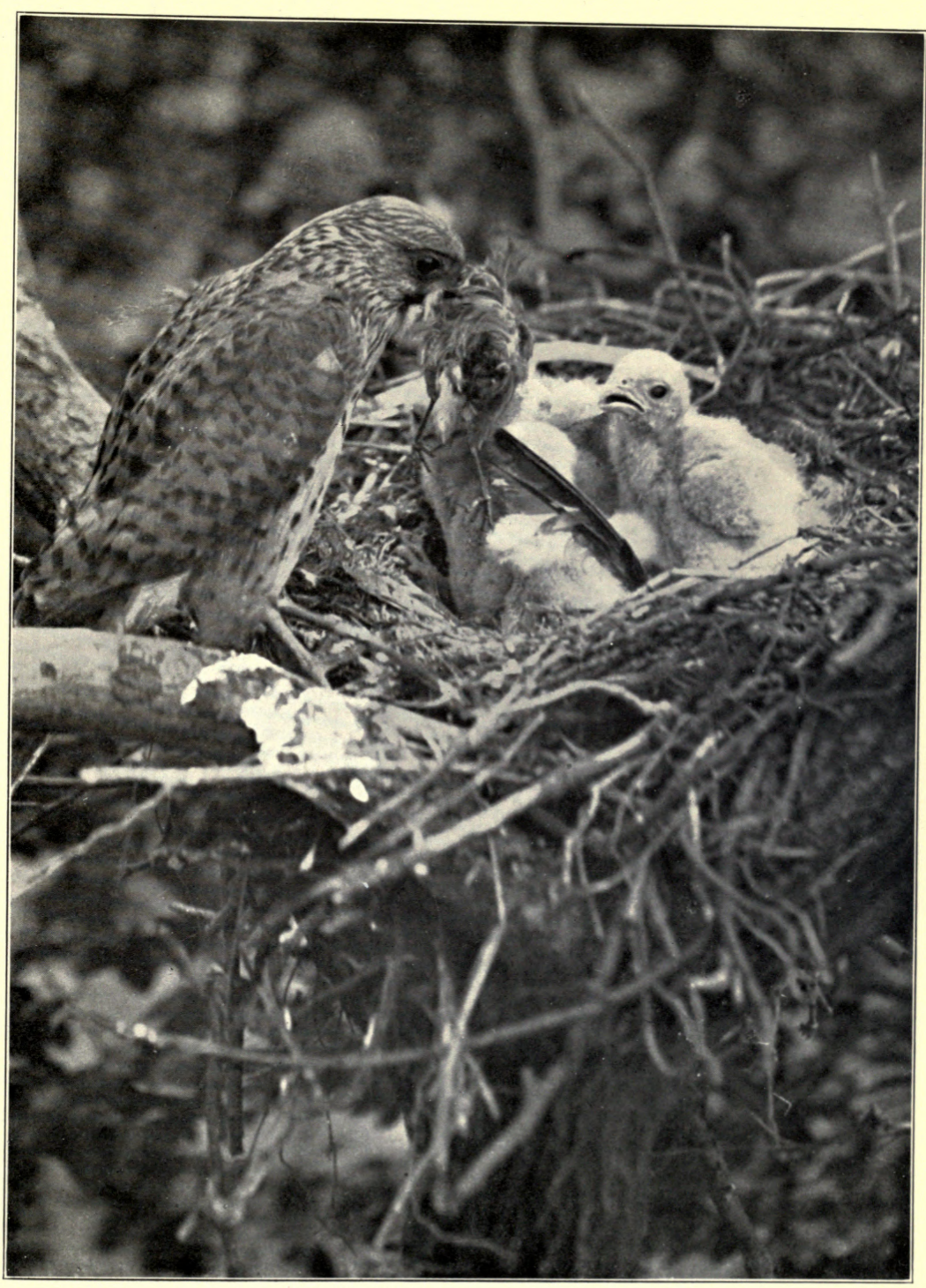

A MEADOW PIPIT FOR THE YOUNG 

A few days later, the young Kestrels, having arrived at the age when they are known by falconers as 'branchers,' had left the nest, and were sitting on the branches about it, spending the greater part of the day in arranging their perfect feathers; taking short preliminary flights from branch to branch, and returning noisily en masse to the nest when any food was forthcoming.

Sometimes one of them would carry the prey, or some portion of it, to a neighbouring branch, where, away from the covetous attentions of the rest of the family, he might enjoy the meal in peace.

And, yet later in their lives, the young Kestrels became so strong on the wing that they did not wait for the parent to bring the food to the nest, but took it from her as she sat on some branch, or on the ground; or-when really strong on the wing-even in the air.

And they quickly learned to fend for themselves.

A month or so ago I watched three young Kestrels which were reared on an old crow's nest some 600 yards distant, hovering over the down-land, and every now and then dropping on to the grass. First one of them and then another, at intervals of a few seconds, would point his wings towards the sky, and drop, feet first-on to an unlucky grasshopper.

This exercise must be good practice for the young Kestrels, and no doubt puts them as it were on the road to more serious accomplishment.

The Kestrel, like the Buzzard, has amongst falconers the reputation of being a miserable and sluggish bird; and by comparison with the Merlin or the Sparrow Hawk undoubtedly is somewhat lethargic.

But that the Kestrel is capable of behaving in a manner belying his disagreeable reputation is perhaps apparent from the following strange story in which I chanced to play a part.

It was on the afternoon of that memorable day the 11th of November, 1918, when, the Armistice being responsible for a holiday amongst the troops stationed in England, a party of us set out for an afternoon with the elusive partridge.

We had hardly started on our expedition when a Kestrel was observed hovering over some rough grass about 80 yards away, and opinions were exchanged as to the likelihood of shooting a bird at such a range, with the inevitable result that one of us decided to justify his confidence in his gun, and his prowess, by having a bang at it.

At the first shot the target merely shifted its pitch a little, but at the second the unfortunate little hawk came tumbling and screaming to earth. As it landed like a tangled bunch of feathers amongst the grass, I was conscious of a sudden pang of remorse. After all, such a bright-eyed, confiding little falcon, even though representing one of the types of what is sometimes regarded as ' vermin,' must at least appeal to the British sportsman as being a charming 
addition to the delights of the country-side, and as such his death must be, in some degree, deplored.

But from my own point of view, having perhaps an unusual affection for the hawk tribe, I must admit that to see one of them falling dead or wounded to earth fills me with something of the same feeling that one experiences when, amidst the rattle and roar of an attack, one sees a comrade stumble forward and collapse in a shapeless heap.

However, the little hawk must be attended to ; and to the joyful tune of the distant sirens, loudly proclaiming that the Armistice had been declared, I ran forward to see what could be done.

He is lying between two tufts of grass with outstretched wings, and head turned so that he may look at me with his dark, frightened eyes. As I stretch forward a hand to pick him up, he crouches lower, and then, flinging himself on his back, prepares with beak and talons to fight for his life. His wings are half opened, and under each of them a smirch of blood glistens on the pretty barred feathers.

With as little to do as possible, I pick him gently up, and since no hood is available, a khaki-coloured handkerchief is wrapped loosely round his head. It is then suggested by one of my kindly comrades that I should ' put him out of his misery' without further delay, and to save further argument I tactfully agree to do so, at the same time making for the quarters where, my friends suppose, the little body will be laid, pending a funeral, for the attentions of a taxidermist.

But, strangely enough, there is little wrong with the hawk. In spite of the blood on the wings there are no bones broken, and I decide that, with careful handling-of the kind that is given to any newly caught hawk-he will possibly recover.

For the next few days, then, he is kept in a dark place, attached by jesses, ${ }^{1}$ swivel and leash to a low screen perch, whilst the wing that drooped most is held up by means of what, in the language of Falconry, is known as a 'brail,' and-most important of all-he is kept undisturbed, and is regularly and properly fed.

But, whatever the cause, he made rapid progress towards recovery, and soon became exceedingly tame. At the end of a week he would sit unconcerned on his perch, and take his food on the fist like any other partially tamed hawk; and then he could not very well do otherwise than get used to the attentions of admiring visitors, including, no doubt, the numerous friends of the batman.

And during all this time the wings were gaining in strength-one was practically sound again, whilst the other, although still drooping, had much improved.

At the end of a fortnight he was able to fly short distances to the fist for his food, and was happier sitting upon the head or shoulder of one of his visitors

1 The leather strips attached to the legs of a trained hawk. 
than upon his accustomed perch. Two weeks may perhaps seem a short time in which to make friends with such an innately wild bird, particularly as he was a haggard, ${ }^{1}$ and had got a number of the mature male feathers already through.

However, so it was, and since it had been decided that 'Armistice,' as he was called, must be capable of catching wild quarry before being liberated, it was next necessary to take him out in the open, and to fly him, attached to a creance or line, to a lure.

There was never any difficulty about this, for the moment that the lure was produced, at a distance of about 35 yards, he made for it, and flew as strongly and as well as one could expect to see a lame Kestrel fly. Then, as the distance was gradually increased, he, getting to know the game, became keener ; and, as his confidence increased, grew more accustomed to people around him ; and to cattle, horses and the like.

Of dogs, however, he had an uncontrollable fear, and should one approach him, he would tighten his feathers and sit, slim and upright, with staring eyes until it was persuaded to change its direction.

But even this aversion was more or less overcome, and whatever his inner feelings may have been he never gave way to them except by sitting very closefeathered and rigid, and perhaps gripping the gloved hand a little tighter than usual. At last, then, the day arrived when he was taken out, freed of his leash and jesses, and flown free to a lure, a distance of about 50 yards. Then he was encouraged to ' wait on ' for a short while-Kestrels will not do so for longand to stoop to the lure. By this time he was flying as well as the majority of Kestrels do fly; quite as well as any of the trained ones that I have ever seen.

But, as has already been mentioned, the Kestrel is a slow flier, and relies on the 'drop' from his hovering position to so accelerate his speed as to enable him to catch winged quarry. And since a trained Kestrel will refuse to thus wait in the air until the quarry is put up for it, one has to adopt other means to impart the required impetus.

In the case of 'Armistice,' it was done by holding the body of the hawk in the right hand, with fingers uppermost and his head projecting from beneath the little finger, and his legs and tail—or 'train'-from beneath the thumb; and by throwing him, at the psychological moment, and with a 'round arm' movement in the direction of the intended quarry.

This, at first, he was inclined to resent, but in time he grew to realize that to be held in this fashion in the hand meant that the lure would soon be produced, and that he would partake of something in the way of refreshment.

Then it remained only to throw him at a sparrow, and to see whether he would be clever enough to take it before it reached cover ; and I must admit that his first attempts were conspicuous failures.

1 A hawk caught in the mature state (not taken as a nestling) is called by falconers a 'haggard.' 
But at last, perhaps when he was feeling in particularly good form, his efforts were crowned with success.

It was on the afternoon of January 3,1919 , when, as he was being carried near some farm buildings, a number of sparrows were noticed scratching about at the foot of some straw ricks.

'Armistice' was quickly relieved of his swivel and leash, and taken in the hand in readiness for a throw. The sparrows were then approached, and, as they rose, he was thrown towards them.

On half-opened wings, he shot like an arrow into their midst; singled out one of them, struck at it, and succeeded only in dislodging a bunch of feathers. As he swung upwards to stoop again the artful sparrow dropped to earth and disappeared, like a flash, under some logs of wood lying near by. Again the eager 'Armistice,' waiting anxiously on the roof of a cow-shed, was called back and taken up. Then, when all was ready, the logs were one by one moved away; gradually the pile decreased until at last only two logs-side by side-were left. One of them is gingerly moved. 'There he goes!' And the little hawk again shoots forward. This time there is no mistake, for he 'binds' to the sparrow in great style, and, what is more, does not attempt to carry it away, and allows himself to be picked up without any fuss.

So it was that, just two months after the firing of the shot that brought our little hawk to earth, he was once again at liberty, for we took off his jesses the same day, and watched him fly on to a limb of a large elm-tree.

During the training of 'Armistice' some curious incidents occurred, in which wild Kestrels were involved; incidents which tend to show that these birds are of a rather jealous disposition.

It happened, as accidents do happen, that when 'Armistice' was flying to the lure one afternoon, he made a particularly sudden stoop, tore the lure from the end of the line, and swung with it into the upper branches of a beech-tree.

Here, indeed, he was beyond our control, and we looked at one another in dismay. There was our little hawk calmly commencing a good meal, and absolutely out of our reach !

What was to be done? Certainly we could not lure him down, or, since he was only half trained, climb up and bring him down, nor could we throw stones or clods of earth at him, as that would only succeed in thoroughly scaring him.

\section{Then it was that a strange thing happened.}

To our surprise he suddenly set up a frantic screaming and almost immediately a wild female Kestrel, swinging into the tree; made a dash at him-or the lure - and the three of them, 'Armistice,' wild hawk and the lure, came tumbling down together in a confused bundle.

Half-way down they separated, the wild hawk making her way towards a tree some 50 yards away; 'Armistice' ruffled and obviously nervous, taking 
his perch on the handiest branch he could find, and the lure, to our delight, dropping safely to earth; to be reclaimed and used a few minutes later for the purpose of bringing back the demoralized 'Armistice.'

But the most interesting incident that befell our little friend happened whilst we were flying him to the lure in open country; he was sitting at the time on a gate-post and we were about to call him off, when a wild Kestrel made straight for him, and, but for our violent shouts and gesticulations, would assuredly have struck him.

Thereupon we decided to try an experiment to discover whether a wild hawk could be caught with a tame one, so, calling our hawk back to us, we attached the swivel and leash to his jesses, and fastened him to a small stump in the middle of the field.

Hardly had we gone $\mathbf{5 0}$ yards away when the wild hawk again made for him, this time bowling him over, and struggling with him on the ground, and only leaving go and flying off as we ran up to help our friend; for we had not expected quite such definite action on the part of the wild hawk.

Again and again we tried walking away from our bird, to find out whether the wild one would again attack, and each time that we did so, back he came to carry on the assault.

And despite our efforts to keep him from closing, he once again managed to dash in and knock the unfortunate 'Armistice' off his perch, the pair of them this time entering into the spirit of the thing, and indulging in a rough and tumble on the ground.

Now there is not the slightest doubt that if we had had a bow-net of some kind handy, we could quite easily have pulled it over both of them, and so secured the stranger as well as the bewildered 'Armistice.'

However, the experiment was never carried out, for we had neither a bownet, nor the desire for another hawk, and in fact it was shortly afterwards that 'Armistice' was given his freedom. Let us hope that he helped to rear a family during the past season. 



\section{CHAPTER $\mathrm{X}$}

\section{Photographing the Crow}

$\mathrm{W}^{\mathrm{E}}$

$\mathrm{E}$ are told in A Catechism of Ornithology, by W. Greathead Lewis (1835), that 'The Crow resembles the Raven in shape, appetites and manners. It is about 18 inches long, and the expansion of its wings is upwards of 2 feet. Its colour is well known, and its habits are extremely disgusting.'

It is a little difficult to know why the habits of this bird should have made such an unhappy impression upon the author, unless of course it is because it feeds upon Carrion - a characteristic which, by the way, is highly valued in hot climates.

Had the author said that its habits are extremely exasperating to the seeker after bird photographs, the writer of these lines would have been in entire agreement with him.

We are inclined, and rightly too, to regard the Rook as a bird of extraordinary discernment ; and yet compared to the Crow he is as an innocent babe.

Temperamentally the Crow tribe would seem to be the antithesis of the Hobby, which behaved in such a confiding manner; for such birds would never dream of coming near the nest if they thought there was the least possibility of any human being even so much as watching from a distance; while they seem to know by instinct whether the strange lump which has appeared by the nest is an empty box or a camera-just as they know whether a dead rabbit or Mallard has fallen unknown to his human persecutors, or whether it has been arranged close to a cunningly hidden trap.

It is perhaps not generally known what difference exists between the Crow and the Rook-and why a flock of Rooks is often described as a flock of Crows.

The main difference between the mature Rook and the Crow has already been explained and although it is not easy to identify either of them if it should be some distance away, one can usually tell to which species it belongs by the surroundings, the location of the nest-if there should be one-by the movements of the bird, and, particularly, by its voice. No one, I think, who has heard the wild, hollow call of the Crow, which is usually repeated three times, 
would be likely to confuse it with the higher-pitched and more amiable cry of the Rook; and a Crow is, by comparison, such a solitary bird.

But even the Crow is not always solitary; and it is interesting to note how, in the summer evenings, the Crows of the neighbourhood will gather together for the purpose, it would seem, of enjoying the raptures of the evening flight.

Sometimes as many as twenty or more, where Crows are common, will be in the air at once, playfully stooping at one another, throwing high up into the air, or corkscrew diving towards the earth. Gamekeepers sometimes take advantage of their knowledge of the fact that Crows indulge in these flights, and if one Crow should fall to the gun, the fate of the remainder is usually sealed. For the Crow, although so exceedingly wary, is, like his cousin the Rook, very curious regarding the unaccountable: and on seeing one of the company crumple up in the air, the remainder usually close in to circle above the spot where the battered body is lying, and try to discover the cause of the catastrophe.

The Crow of course is a very much persecuted bird, and it is amazing to find how, with every man's hand against him, he contrives to exist in such numbers. His life must be one long struggle to avoid the man with the gun, the invisible trap, and the poisoned meat-and he would probably have been exterminated by now were it not for the brains with which Providence has blessed him.

The number of Crows' eggs constituting a clutch seems not to vary nearly so much as in the case of the Rook, for while the latter almost invariably rears from one to six young ones, the Crow's nest almost invariably holds either four or five.

As a rule the nest is not placed so high in the tree as the Rook's generally is; for the Crow seems to like rather to construct his home at some point where it is less conspicuous than if it were amongst the topmost twigs, although it is, nevertheless, generally at a very considerable height, and almost always in such a position as to allow the sitting bird a good view of the surrounding country.

A Crow's nest is an unusually strongly built affair, and has as its foundation a collection of interlaced sticks, many of which are considerably larger than an ordinary pencil in circumference, and sometimes measure a couple of feet in length. Between these, and the inner lining of wads of bullock's hair and wool, is a thick layer of mud, or cow-dung : which, placed in position in the damp state, ultimately dries and forms a firm cup that is not easily penetrated; which accounts for the fact that a Crow not infrequently flies unscathed from a nest at which a charge of shot has been fired from below.

I have, during the last two seasons, discovered a couple of Crows' nests which pointed to the fact that they had been constructed by birds of certain 
A

YOUNG CROW
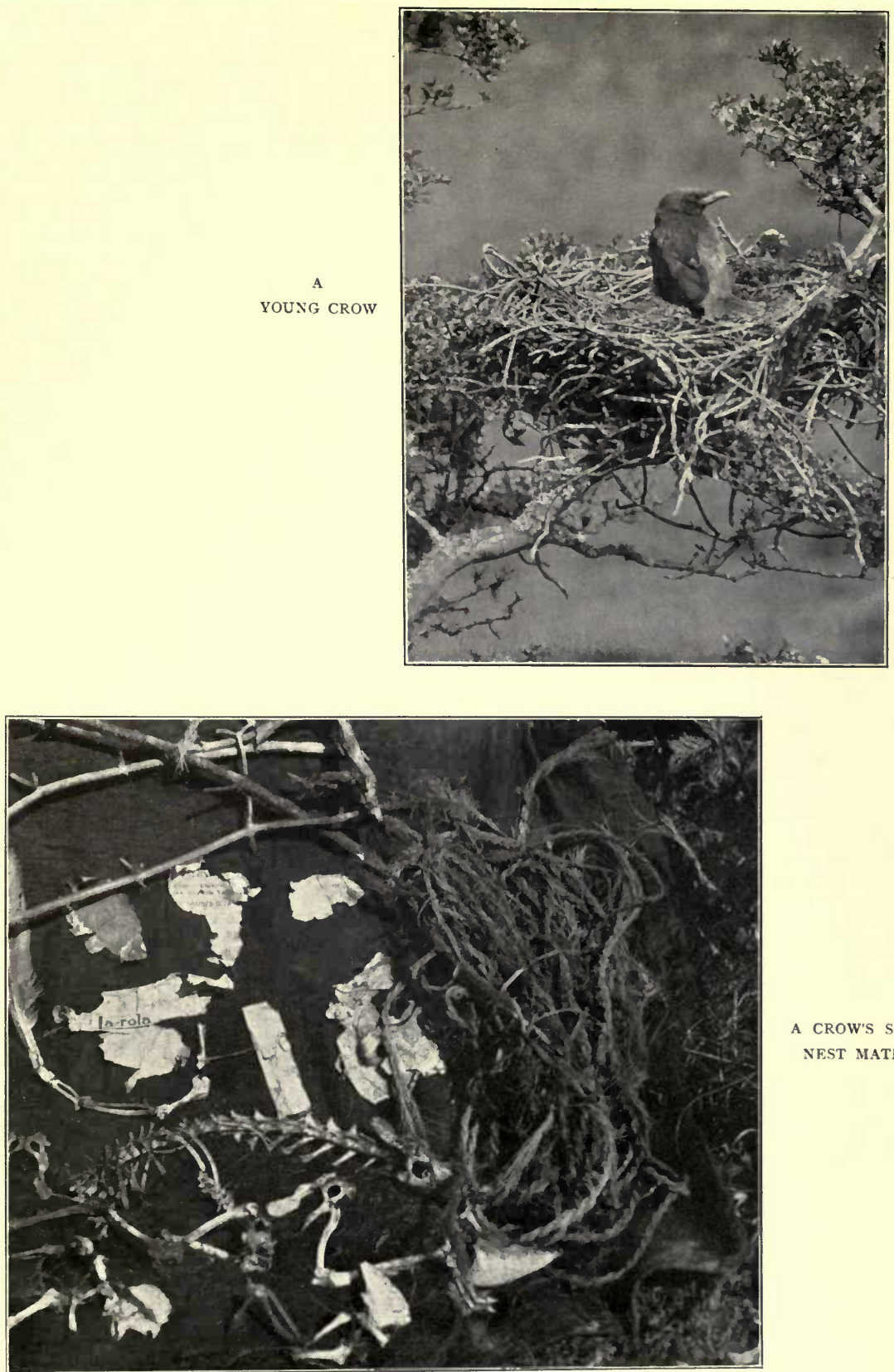

A CROW'S STRANGE NEST MATERIALS 

artistic tendencies - or birds that wished to be reminded during their inactive hours, of past feasts. For the foundations were largely composed of the bones of departed birds and animals. One of them included the vertebræ of two rabbits, together with the skulls, which had become disconnected ; the greater part of two moorhens' skeletons, with the flight feathers still intact; the remains of several pheasants, including the breast bones and spurs; and a few bones of a red-legged partridge. In addition to this collection were quantities of the string which is used for tying sheep gates together, some cigarette packets, and what was once a lady's handkerchief. An accompanying photograph of some of the materials used in the construction of the other nest suggests that the Crows were of a somewhat literary turn of mind, or that they liked to see the dull monotony of the home relieved by touches of a lighter shade.

The Crow's nest which we selected for photographic purposes from the many that we discovered in the district, was built in the upper branches of one of a row of elm-trees, overlooking the marshes on one side, and a wide expanse of arable land which stretched away to the uplands on the other, so that to approach unseen to within less than half a mile of the place was impossible. It might at first seem strange that a nest in such a situation should have been chosen, particularly as the height at which it was built made an unusual amount of climbing necessary. But it was selected for two reasons: firstly, because it was eminently satisfactorily placed from the pictorial point of view-incidentally a most important reason; and secondly because it was in a position, and at an elevation, that could not be reached by the ordinary school, or farm, boy.

When the first stage of the 'imitation camera,' consisting of a small piece of sacking camouflaged with leaves, was first tied in position, the Crows really seemed as though they had no further interest in their nest, for, although they sat composedly on the topmost branch of a dead elm close by, they never even glanced in its direction.

From behind a hedge some half-mile away we watched them through glasses, and as we had fully expected to see them go on to the nest at the end of, say, half an hour, we felt somewhat disappointed when, at the end of an hour and a half, they were still amusing themselves on the top of the dead elm !

As the sacking which had been left in position was not larger than an ordinary cap rolled up, and was well garnished with elm leaves, we felt dubious as to whether we should ever succeed in getting a photograph-and then the awful fear occurred to us, that the leaves on the roll of sacking would wither before the Crow found courage to return to the nest, and thus make the cause of her fears more trap-like than ever.

However, on our next visit the Crows seemed to be quite reconciled to the strange innovation, and from a distance we watched them going to and from the nest. 
They invariably approached it by flying within a few feet of the ground until close to its foot, and then swinging suddenly up and on to some convenient branch. And they would leave it in a manner characteristic of Crows-that is by literally dropping from the side of the nest until within a short distance of the ground, and going away with wing tips almost brushing the turf.

So the size of the dummy camera was daily increased until, at last, the thing was so bulky as to suggest a canvas bolster lodged in the tree. And of this the Crows, having overcome their first feelings of suspicion, ultimately took not the least notice. On the 6 th of June it was decided that an attempt should be made to secure some photographs of the 'home life of the Crow.'

And as we approached the place on the morning of the fateful day, we were delighted to see that both of the Crows were making frequent and confident visits to their young, in spite of the fact that a piece of loose sacking hung from the dummy camera and flapped idly in the breeze.

Really things looked most promising-perhaps after all the Crow would not be so difficult a bird to outwit. So we silently thought as we trudged towards the row of elms, and at length laid our impedimenta at the foot of the tree.

As usual I carried the camera up with me-also the little platform for itand the ball of string; and again, as usual, things for a while went hopelessly wrong. When I attempted to drop the ball of string, it caught in a branch half-way down the tree, which necessitated my climbing down to set it free; then having at last fixed the camera, I found that a projecting branch prevented the focusing arrangements from working properly, and lastly the screws which I had brought for the purpose of fixing the platform in position were too short, and refused to hold in the wood until the whole thing had been taken down, and the bark pared off.

But at last everything seemed to be in readiness, the Crow's nest was focused, and the string arranged as in the case of the Spotted Woodpecker, through a series of 'screw-eyes' to the hiding-place; which in the meantime my companion had constructed.

It was in every way but one an excellent hide-very much like the worst type of dug-out-its one drawback being that it was not nearly large enough to conveniently hold a human being-and since my companion was an enormous man, it seemed strange that he should not have made it on a larger scale.

However, that the Crows, wherever they might settle, could never see into its interior was a very distinct advantage, as was the fact that from the inside of it an excellent view of the nest could be obtained.

Past experiences have convinced me that more than two people are really necessary on a Crow photography expedition, at least where there is no cover, for the Crow, who of course watches everything from afar, is not satisfied if, having seen two people approach a place, he sees only one go away from it. 
When there are three or more people, the absence of one of them on their departure is not so likely to occur to the Crow; for we cannot suppose that the Crow literally counts, but rather that the idea of greater or lesser numbers makes some sort of mental impression.

But since, on this occasion, there were but two of us to carry out the scheme, it was decided that I should wait in the hide for the Crow to go on to her nest, and that my companion should endeavour to make himself as much like two people as possible by taking off his coat and carrying it at arm's length, in as ostentatious a manner as possible.

So I crawled into the little dug-out, and having been duly covered in, heard my companion say, ' Well, I'll go now : if you're all right.' I replied that at present I was sufficiently comfortable, but that I expected an attack of cramp during the next hour. A little later, on peeping through a little spyhole, I saw a large figure, which, as it receded into the distance, frantically waved its coat in its outstretched right hand.

Whether it was owing to this ruse or not, it is impossible to say, but within an hour one of the Crows had returned to the branch at the top of the dead elm. I am doubtful as to whether I should have known that she had taken up this position, had it not been for the 'woof-woof' of her wings as she passed, quite low down, over my hiding-place, before swinging up on fully extended wings to her favourite perch.

From the hiding-place I had an extraordinarily good view of her, as she sat with uplifted head, watching for any unusual movement. What a magnificent bird. With her powerful curved beak, thick glossy neck, and glistening sides, she looked exactly like a miniature Raven.

And what an unconscionably long time she spent in gazing about her, preening her flight feathers and stropping her great beak! As might be supposed, the act of gazing upwards from such cramped quarters brought on all too soon an aching of the neck which became most trying. But at length, and just when the neck-aching had grown to be almost unbearable, the Crow, without the least warning, suddenly planed down on half-closed wings to within 6 feet of the ground, and sneaked-if flying at such an altitude may be so described-towards the foot of her own tree. Then of a sudden she swung upwards, and landed with incredible ease on the edge of her nest, where for a few moments she remained, immovable before attending to her wheezing family.

I had previously made up my mind that I would not attempt an exposure until I saw that she was actually feeding the young, at which time, one would suppose, she would be too intent on her duties to notice any possible movement of the string. I, however, had under-estimated the wariness of my subject, for as I commenced to tighten the string, I saw her head shoot up-alert, suspicious-and in a flash she had gone. 
How sadly I wished that the string had not been so slack! In any case it must be tighter next time, and I straightway gathered in as much as I dared without releasing the shutter, and once more awaited the coming of the Crow.

And at last once again she came on to the dead elm: once again she swung on to the nest to face the yawning youngsters, and once again the string was pulled in vain.

So there was nothing for it but to crawl out of the hiding-place, and climb up the camera tree to disentangle the string; and incidentally to reset the shutter which had acted after the Crow had left the nest. And then to enter the dug-out once more.

But here a fresh difficulty presented itself, for soaring high in the air above were both of the Crows, intently watching everything that was going on below.

I realized that it would be hopeless to walk openly, and enter the hide whilst the Crows were thus looking on ; and conceived the bright idea of endeavouring to outwit them by an ingenious subterfuge.

It happened that the hiding-place was constructed in a ditch at the corner of a field of growing oats, and I thought that, if I waited until the Crows had settled-as they generally did-on the distant marshes, I might quite well crawl on hands and knees through the oats, and thus enter the hide without being seen.

And in due course, the Crows having settled in the desired manner, I commenced my arduous and-owing to the presence of numerous thistlespainful journey through the oat-field. At last I had reached the edge of the oats, and only had to cross a yard or so of rough grass before I should be safely in the hide again.

And as I crossed the small piece of comparatively open country, I chanced to glance sideways to see both of the Crows seated on a couple of tall poles on the marshes, gazing suspiciously at my amateurish antics !

So, feeling thoroughly annoyed-and very stupid-I set out in search of my companion-only to find that he had completely vanished.

And after a good tramp around the country in search of him, I eventually enrolled the services of a shepherd, who promised to see me safely into the hiding-place, and then to withdraw as noisily as possible.

And when he had gone, I pondered over my chances of being successful this time. The string was now in a position where it could not be seen from the nest-not even by the Crow. My entrance into the hide had been cleverly executed; the Crows would surely soon go on to the nest to feed, and the light was unusually good.

As I thought over these things, one of the Crows returned to the top of the dead elm, and for the first time during this trying day, I felt quite delighted at the prospect of making an exposure so soon.

But an instant later my heart sank within me. The kindly shepherd had 


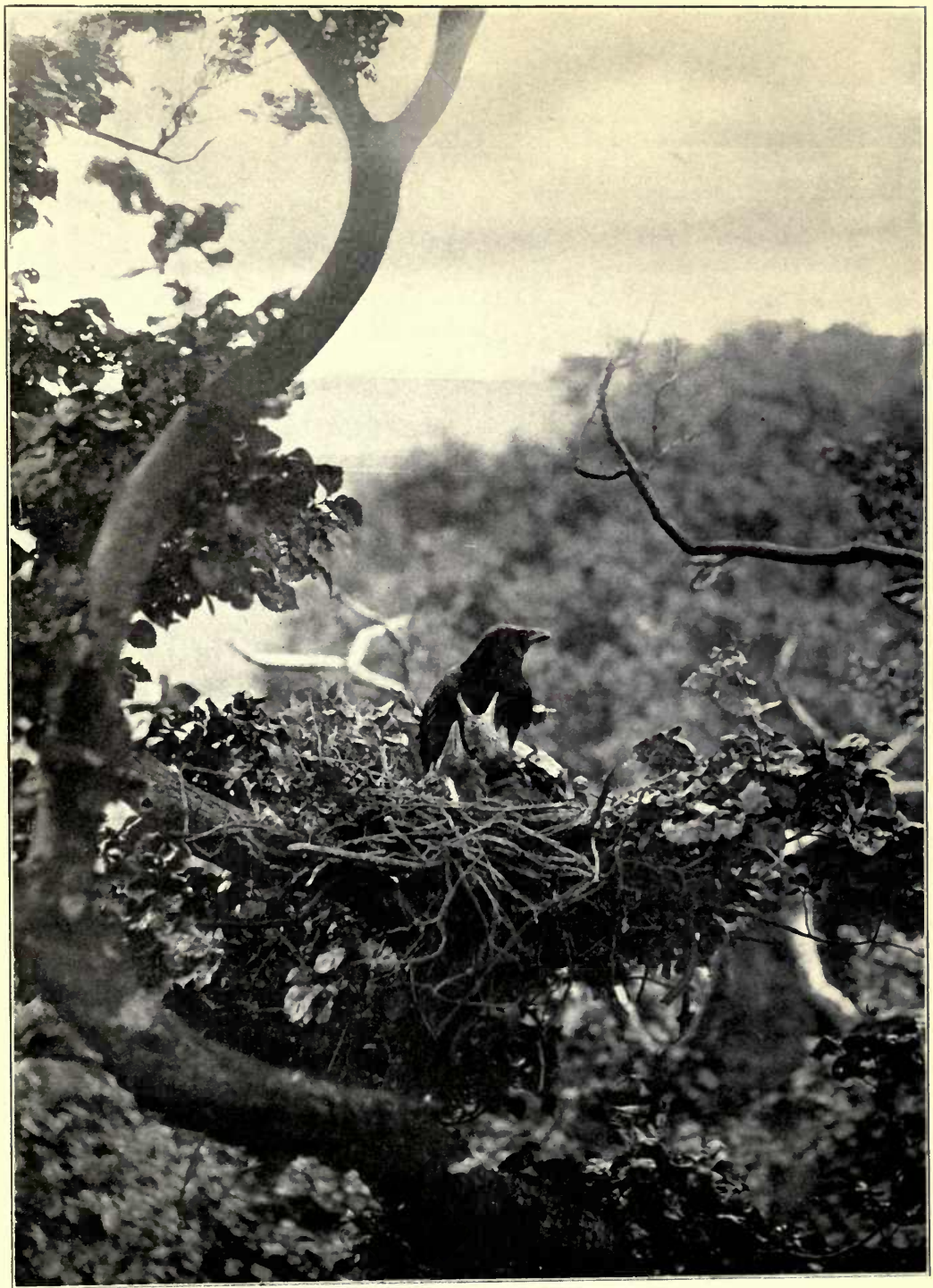

SUSPICION : 

left his sheep in the field across which my string ran to the foot of the camera tree, and even as I looked I saw them slowly advancing towards it.

And in a few moments, as they meandered along, their feet became entangled in it, an unsolicited exposure was made, and the string was broken !

I now decided to abandon the idea of Crow photography for the day, and having re-arranged things, set out in search of my companion. At last I found him comfortably reclining in the shade of a spreading oak, and acquainted him with my doleful news.

He was most sympathetic, and even suggested that on the following day he would like to take a turn in the hiding-place and see if he could not do better. I ventured to suggest, as I thoughtfully regarded his enormous frame, for he weighed some 15 stone, that he might perhaps find the place a little on the small side. ' $\mathrm{Oh}$, that'll be all right,' he answered cheerfully; 'I shall be comfortable enough.'

And so it was arranged that, on the following day, he should lie in wait and try for a photograph of the Crow.

And in due course we arrived on the scene of action: the camera was prepared, the string arranged, and everything in readiness for the great effort.

'You are sure you can get in ?' I asked my friend as we stood at the entrance of the hide.

'Of course I can,' he replied, and therewith sank on to his hands and knees with the idea of proving his statement.

His head and shoulders slowly disappeared into the little opening, while his back parts-which he seemed less able to control-almost lifted the entire roof from its position; which reminded me of the manner in which packs used to catch against the roofs of low dug-outs in France.

But at last he was safely inside, and thoroughly covered in.

'All right?' I asked.

'Yes, thanks,' he replied.

'Got the string?'

'Yes.'

'Everything in order ?'

'Yes.'

'Can you see the nest?'

'No.'

'Well, how the dickens will you know when to pull the string ?'

However, having managed to discern the nest, and feeling that everything was really in readiness this time, he told me that I could go away. ' All right,' I said, 'I'm going now. Don't forget : if the Crow comes on to the nest-Pull the string.'

What happened next I do not know-except that when the Crow did 
ultimately visit the nest he pulled the string so hard that the shutter became detached from the front of the lens-!!

But in the end, and after two weeks of unsuccessful efforts, one photograph, and one only, of the Crow at her nest was secured, which is reproduced among these pages.

Young Crows are fed by the old ones for some time after they are able to fly, and may be seen following with fluttering wings in the wake of the parent as he-or she-struts here and there on the look out for suitable food.

The Crow, like the Rook, feeds largely upon the larvæ of various insects ; but is also very partial to the flesh of dead animals, or birds, which it may find lying in an open place, such as the middle of a marsh, and invariably first extracts and swallows the eye which is uppermost, before troubling to get at any other more succulent portion!

The photograph of the young Crow, which also appears in these pages, was taken in the Doone country, and shows a nest which was built in quite a low hawthorn-tree growing from the side of a steep and rocky bank.

When we found the nest it contained four young Crows, which, unhappily for us, were almost ready to fly.

Had the nest belonged to any other bird, we should, no doubt, have obtained some unusually pictorial results, showing the old bird and her family; but since it was a Crow, we were doomed to disappointment. For the parent birds, by calling to the young from a distance, induced them to attempt the first flight, and it was by good luck rather than judgment that we succeeded in getting a picture of the last of the young ones a few moments before he too went off into the world. 


\section{CHAPTER XI}

\section{Concerning a Sparrow Hawk Family}

$\mathrm{O}$

$\mathrm{NE}$ has only to see a Sparrow Hawk at really close quarters to know, by its expression, the shape and size of its feet and talons, and the threatening way in which it fixes its cold yellow eyes on to anything in the way of food, that it is a bird of indomitable spirit-a creature of wild impulse and inexorable purpose.

There is, to me, something particularly dramatic about the pose of a Sparrow Hawk when out for blood-particularly a female-as hunching her shoulders she glares around with slow moving head and eyes that literally squint with eager expectancy.

And with such lightning speed does she-as it were-'dive' after any unsuspecting quarry, and snatch at it with her needle-sharp talons, that the business of securing the victim is finished and done with before the amazed onlooker has clearly realized what is taking place.

But should this first impulsive dash prove unsuccessful, the Sparrow Hawk does not, like the Merlin, persevere in the hunt with the idea of wearing down the quarry; but swings away either to take perch upon some convenient bough or leisurely to continue her flight. Should she adopt the latter alternative, she keeps to within a few feet of the ground, swerving just sufficiently to avoid any obstacles that she may encounter, or surmounting them with the careless ease that is typical of the short-winged hawks : though it is a bad day for the blackbird or thrush, intent on turning over the leaves in search of food, who is thus surprised by the dreaded form.

Owing to this habit of gliding over the ground, and pouncing upon some victim, the Sparrow Hawk is quite frequently caught in the nets of bird catchers, as she makes for one of the decoy birds. It is, of course, the aim of the man at the end of the line to close the net at the exact moment that the hawk strikes, and thus prevent further visits of a like nature. But he who can thus catch a Sparrow Hawk in the act of striking at its quarry must indeed be an expert, for the speed with which a Sparrow Hawk dashes at its quarry must really be scen to be understood. 
And it is upon this sudden onslaught that the Sparrow Hawk relies for the capture of her food. So intent is she on the business that she has frequently been known to dash against-or through-a window in her efforts to secure some bird on the other side. To my own knowledge a Sparrow Hawk a few years ago crashed against a cage, and held on to its wires in her anxiety to gain possession of the canary inside!

One cannot, consequently, compare the speed of a Merlin, or Hobby, with that of a Sparrow Hawk, for both of the former will think little of travelling the best part of a mile or more in the process of wearing down the victim, whereas, as has been explained, the Sparrow Hawk's dash is a short-lived effort, and is either at once a success or a failure. Its method of hunting is, in fact, entirely different from any other of the resident British hawks.

In general appearance, too, the Sparrow Hawk differs very widely from the others. In the first place it belongs to the short-winged hawks, that is those hawks whose folded wings do not extend for more than about half the length of the tail; then it has deep-set, yellow eyes, that tend to add to its already ferocious appearance, and particularly long legs, which are of the utmost value in enabling it to snatch up quarry even after the latter has dived into thick cover.

There is also a greater difference in size between the male, and female Sparrow Hawk than is the case with the others; and, compared to his enormous and more ferocious-looking wife, the little male is indeed an insignificant, meek little man, who looks as though he ought to belong to another species altogether.

A good deal of controversy has arisen as to whether the Sparrow Hawk constructs a nest of its own, or whether it utilizes the disused one of some other bird. I have in the course of many seasons discovered some dozens of Sparrow Hawks' nests, which, with the exception of three only, had all been built entirely by the birds themselves; in fact, I have often discovered a partially constructed Sparrow Hawk's nest which I have identified directly, and which has ultimately held a clutch of Sparrow Hawk's eggs.

As to the three exceptions, two of them were properly constructed Sparrow Hawk's nests, which had as their foundation the remains of an old squirrel's drey, and the other was a more slipshod affair, built on the remains of a several years' old crow's nest.

The majority of the Sparrow Hawks' nests which I have known have been in fir or larch trees, but in many districts, including that in which the accompanying photographs were taken, they are invariably built in deciduous trees - possibly because the other kind are not available.

The birds seem to be fond of using the flexible ends of larch branches as a foundation for the nest, and small pieces of the bark of pine-trees as an inner lining; though where these are not to be obtained they have to use as a founda- 


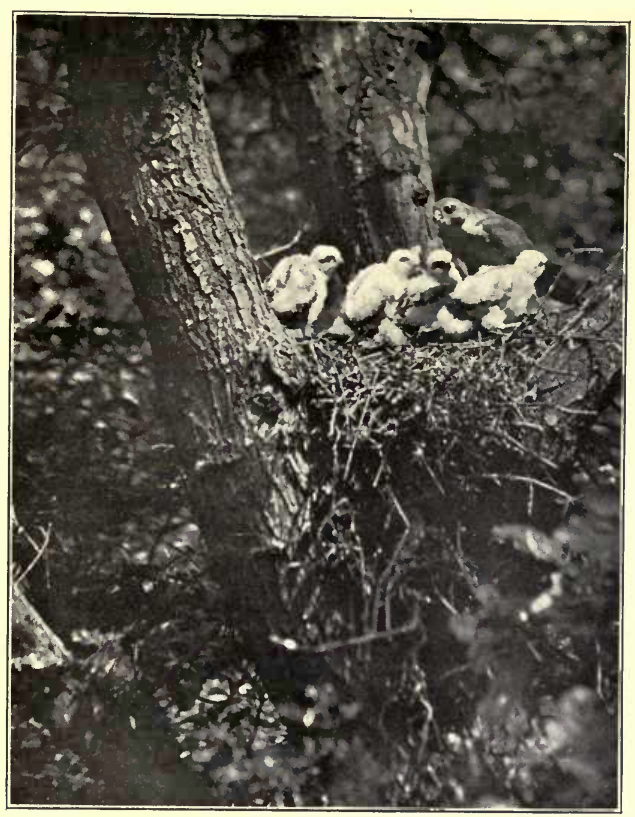

THE SPARROW-HAWK

THE FAMILY LINE-UP

FOR THE MEAL-

AT A IATER STAGE

THFY FEEI) THEMSELVES

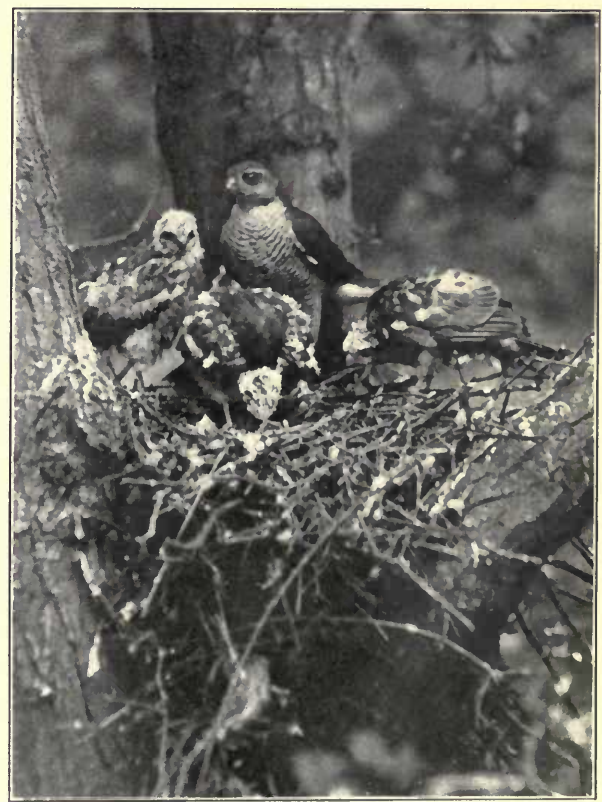



tion the less artistic sticks that are lying about : and, as a lining, either small twigs or green leaves.

Then the food of the Sparrow Hawk-like that of the Little Owl and the Kestrel-has been the cause of yet further agitation. The grievance being, as in the case of the others, that it destroys game birds.

And we may as well admit at once that the Sparrow Hawk is the one common bird of prey of these islands which is able to kill, not only quite small pheasants or partridges, but birds which are considerably heavier than itself. For, unlike the Kestrel and the Little Owl, the Sparrow Hawk does not usually betray its presence until it is in the act of making the final dash. And, in addition, it is courageous enough to attack young pheasants that are assuming their mature plumage, and strong enough to carry a plucked bird as large as a wood-pigeon to its nest.

Most of the Sparrow Hawks' nests which I have examined after the young have flown have contained the bones of such birds as doves, blackbirds, thrushes, sparrows, and other small fry ; whilst I have on rare occasions found the remains of jay, cuckoo, night-jar, wood-pigeon, and green woodpecker.

Two nests that I have in mind, however, were literally piled up with the bones of defunct young pheasants-and it would seem that the parent hawk, having discovered that it was possible to overcome such large and abundant fowl, had acquired the habit of making a dead set at them. It is significant that both of these nests were in the midst of very large preserves, where there were not many bushes, and where in consequence there was a shortage of small birds. For the Sparrow Hawk does not select a young game bird, if there are blackbirds, starlings, or some lesser fry to be had. It will, however, acquire the habit of taking them if these others are not in sufficient quantities. That at least is what my own experience has taught me. The inference that Sparrow Hawks hunt in the immediate neighbourhood of the nest might be drawn from the foregoing remarks, although it is far from my intention to suggest that such actually is the case. As a matter of fact I have never yet seen or heard a bird caught by a Sparrow Hawk anywhere in the close vicinity of the nest; though I have on many occasions seen the male approaching the nesting wood from a distance with a bird in his talons, and believe that hawks invariably prefer to hunt at some little distance from the home.

During the time that the nest is undergoing construction, the Sparrow Hawks may often be seen soaring at a considerable height-particularly when the sun is shining-and, up to the time when the female is sitting, they usually spend part of each day in thus taking the air. Sometimes a pair will be joined by a third-and the three of them will circle above the trees in perfect amity : in fact it is by seeing the hawks thus soaring that one may often discover their nest.

I have always had such a profound admiration for the Sparrow Hawk 
that I had hoped for many years to have the opportunity of watching-and perhaps photographing-the growth of a family of them from the time that they emerged from the egg until the day that they left the nest.

Not until the summer of this year of 1921 was I able to fulfil my ambition. I should not even then have been able to do so had it not been for the kindness of the proprietor of the estate in agreeing that the hawks should not be molested.

Towards the end of May the nest, which was built in an oak-tree, held six beautifully blotched eggs, that I judged were only slightly set. I was somewhat surprised to find that this was the case, as the bird had sat very tightly when I approached the tree, and I had rather expected to find that the nest contained young.

It was not until June 12 that the eggs were ' chipping,' by which time the observation post was nearing completion, and it was on that day, whilst inside it arranging the finishing touches, that I first saw the female Sparrow Hawk at close quarters.

The building of the observation post, which was 11 feet from the hawk's nest, had, of course, covered quite a long period, and until this particular day I had never remained in it for very long, in case the hawk should return to her nest whilst I was inside, for my sudden appearance would no doubt have scared her very considerably. On this occasion, however, I had decided to finish the job, and thinking that the hawk might return before I had done so, I had taken the precaution of tying to the end of the rope which I used for climbing to the observation post a couple of branches ; so that, by jerking the rope up and down, the branches would clatter on the ground and the hawk, thinking that some one was walking under the trees, would leave the nest, and so give me the opportunity of decamping unnoticed.

But although I had half expected that she might return, I experienced quite a shock when, on peeping through the observation hole on to the nest, I saw that she was preparing to cover the eggs! She really was a magnificent creature, and, judging by the extraordinary blue of her back, she must have been very old; in fact she was almost as blue as the male, who later on occasionally visited the nest, and seemed by her side to be quite a pigmy hawk. Still, he was in beautiful order, and had brighter cheeks, breast, and thigh tufts than his mate.

It was indeed a delight to watch so beautiful a bird at such close rangeparticularly as she took no notice of any slight movements within the observation post.

When I returned to my friends that evening, I was so pleased with my experience that I tried to induce them to agree to sit in the observation post for an hour or so one day, just for the joy of watching at such wonderfully close range, and in such comparative comfort, one of our shyest birds. But 
although they all agreed to do so, and their enthusiasm seemed to be genuine enough, not one of them ever carried the promise into effect !

On the following day, having at length fixed the cinema camera in position and made myself more or less comfortable on a seat which I had previously arranged, I sat with my eye to the look-out hole, awaiting the coming of the hawk.

I noticed that four of the eggs had already hatched, the little hawks, with the remaining two eggs lying huddled together in the middle of the nest. Judging by the experience of the previous day, I felt pretty sure-since every precaution had been taken not to scare the old bird-that she would soon return to the nest; and as it turned out my surmise was correct, for within twenty minutes she suddenly, and without the slightest sound of warning, appeared on the edge of the nest. So silently and so unexpectedly did she arrive that, close as I was to her, it took me a fraction of a second to fully realize that she was there.

For a little while she stood erect on the side of the nest, with her head inclined forward, in a listening attitude, and with one yellow eye fixed intently on my hiding-place. Then presently, having it seemed satisfied herself that all was well, she puffed out her feathers, and lowering her body so that her toes just protruded beneath her breast feathers, commenced to shuffle in the most awkward way towards her young. I have never seen any bird except a hawk prepare to cover her eggs or young in this extraordinary fashion-which, by the way, reminded me of the actions of the Hobby and the Peregrine.

Having eventually advanced sufficiently far to be able to cover the young, she spent some little time in raising and lowering her body, and in shuffling about before settling comfortably down to brood. Once more I gazed admiringly at her as she sat in the bright sunshine. Her back looked bluer than ever, whilst her golden eye with the projecting brow, her delicately lined breast, and perfectly formed tail, combined to complete the most beautiful Sparrow Hawk I have ever had the pleasure of seeing.

What a sin to shoot such a creature!

She had not brooded the young for more than ten minutes when, from the trees on my right, I heard the subdued, long-drawn call of the male, a soft ' $\mathrm{p}$-e-e-e-w' repeated two or three times. At once, and again without a sound, the female had left the nest, and was absent for some twenty or thirty seconds. Then, as unexpectedly as before, she was standing again on the edge of the nestthis time with a small bird grasped in one foot.

I could not tell exactly what species of bird this was, since it had already been thoroughly plucked by the male, and in addition was minus its headthough from its shape I should say, with some degree of certainty, that it was some kind of warbler - a whitethroat perhaps, for the woods literally abounded with these little birds. 
And as to its head being missing-I have usually noticed that the birds brought to the nest by Merlins, Hobbies, Kestrels, and Sparrow Hawks have been decapitated, no doubt because the male, feeling that his efforts are entitled to some reward, generally eats the head himself.

Such a tiny bird, encircled by the female's talons, looked ridiculously small, and to all appearance she could have managed one several sizes bigger; for, holding it on to the nest with the two large middle talons of each foot, she wrenched pieces off with her beak with the utmost ease; and legs, breast, wings, and what few feathers were still adhering to them, disappeared with the same facility.

Her meal finished the hawk once more puffed out her feathers, and shuffled on to the family-though I noticed that she did not during that morning feed them at all-no doubt because young birds when first hatched do not require food for some little while.

On the following day another young hawk had hatched, and the old Sparrow Hawk seemed to be even more solicitous for the welfare of her family than on the previous day; for I had hardly settled myself in the observation post when she returned to the nest, and with very little hesitation commenced to shuffle forward towards them.

On visiting the nest just ten days later I was surprised to see-from the observation post-that there were now only four young ones in the nest, and decided to climb up to see if I could account for the disappearance of the fifth.

The egg I discovered was still intact, and obviously bad, so I threw it overboard, but the missing youngster I failed to trace until I had returned to earth, where I discovered it lying dead on the ground beneath the nest.

So, the problem solved, I returned once more to the observation post and prepared again to await the return of the old bird. Once again she behaved in the most pleasing manner, coming on to the nest before $I$ had been in position for many minutes, and again shuffling towards her young. This time, however, she did not cover them, but instead turned her back towards the sun, which was beating down directly on to the nest, and, by spreading her wings and tail, made a sort of shelter, under the shadow of which they could take refuge from the hot glare.

The old Sparrow Hawk seemed to feel the heat very considerably herself, for she had her beak open as though panting for breath-though it is not at all unusual for any sitting bird to open her beak if the sun should be shining on to her.

At exactly mid-day the plaintive cry of the male sounded from his favourite tree on the right, and in response the female slipped silently off the nest.

It may be a coincidence, but $I$ have never yet seen the male of any species of hawk take food actually to the sitting female-though $I$ have on countless occasions watched one of them bring it to the vicinity of the nest, and have seen 


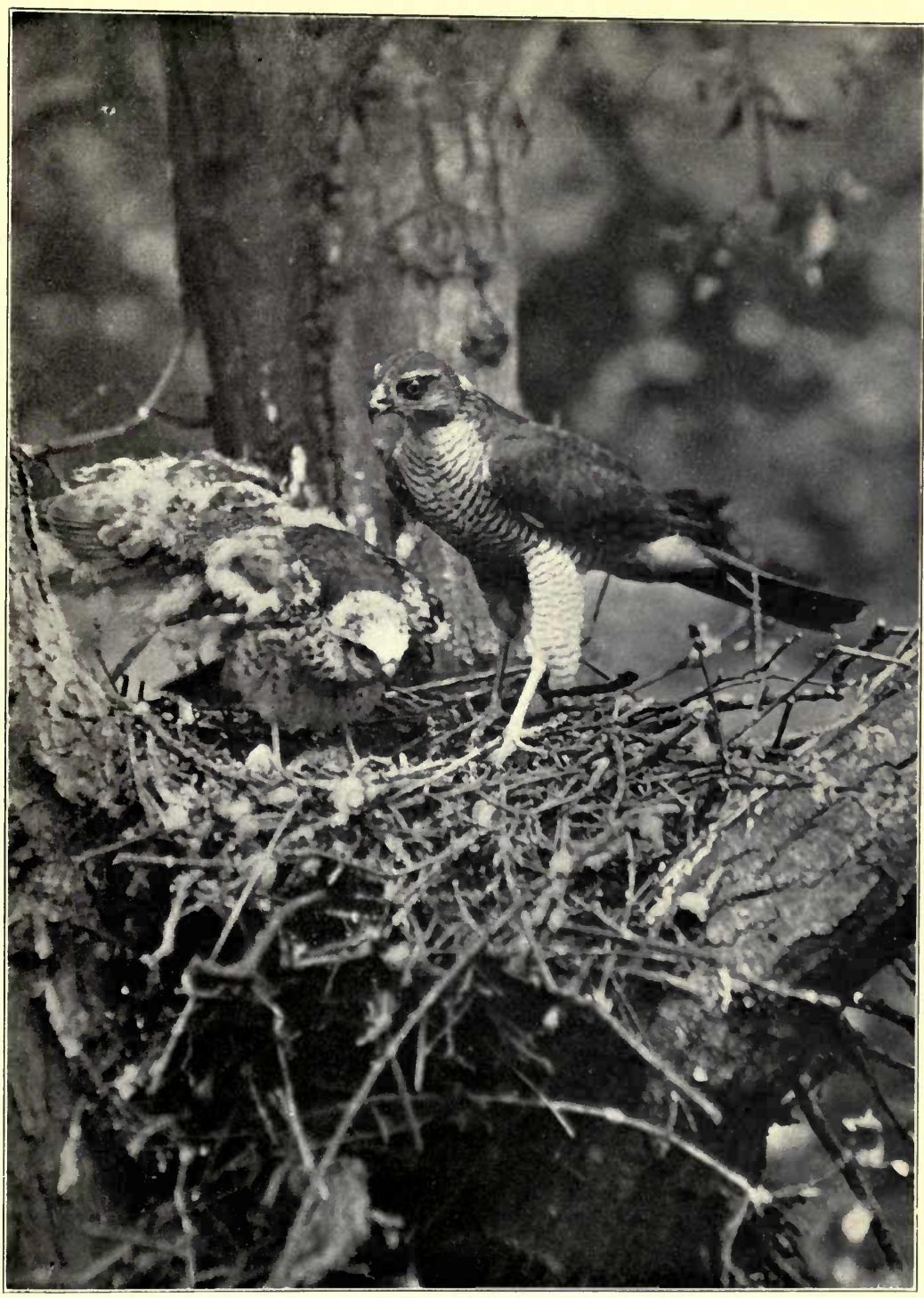

'IIIE SPARROW-HAWK'S WILD EYE 

the female in response to the call leave her eggs or young to meet him, and secure the prey.

When the female returned to the nest she again had a small bird in her talons, which, as before, lacked its head, and the majority of its feathers. Holding this down as on the previous occasion she commenced to tear off tiny pieces, which the youngsters, who had lined up before her as though expecting a feast, pecked from the tip of her beak as it was held out towards them.

Occasionally she would offer to them an awkwardly shaped piece, which the recipient would find difficult, or impossible, to swallow; and then, noticing his unsuccessful struggles to get rid of it, she would take it into her own beak again and swallow it herself.

Considering that the young ones were only ten days old, they had grown, as young creatures do grow, in an amazing manner-already they sat up on their elbows in splendid style, and had looked at me in the most perky way when I climbed up in search for their missing brother.

The quills too were already coming through the down, although no feathers were yet apparent.

At about three o'clock, the male brought another bird to the trees, which looked, when the female had carried it on to the nest, like a sparrow, or a greenfinch.

Just a week later another visit was paid to the hawk family, though, before climbing to the observation post, I helped my companion to construct a hidingplace some distance away, from which, with the aid of glasses, he would be able to see the goings-on in the nest.

Whilst we were making the hiding-place the female Sparrow Hawk, no doubt watching our movements, soared above the trees. Our presence in fact seemed to have a disquieting effect on her temper, for she made wild dashes at any dangerous-looking bird that came anywhere near to her. At one time three crows were flapping innocently overhead-when the little hawk, recognizing in them some possible enemies, shot up into their midst, and sent them flying in all directions. One of them she singled out for further attacks, and the unhappy crow really seemed to be exerting himself to the utmost to avoid her furious onslaught. As she swung at him he would turn head downwards and with wings spread and tail pointing to the sky, came swishing and gliding towards the earth like a piece of cardboard that is thrown edgeways into the air.

A little later a Heron reposefully sailed along in the direction of the heronry, and the hawk, now thoroughly worked up, shot after him as though he, too, were an arch-enemy; the poor Heron squawking frantically as he endeavoured, by doing a corkscrew nose-dive, to get clear of the feathered termagant !

When I ultimately looked on to the nest from the observation post I could not help a feeling of surprise that the young hawks had developed so much since 
I had last seen them, for now the brown feathers of maturity were already replacing the down of youth, while they spent the major portion of their time in standing upright on the nest, and preening and arranging their growing feathers. As before, they were fed at mid-day, but this time received a further supply of food at one o'clock, and yet more at about three.

As they were finishing their mid-day rations, the male settled on the nest, perhaps to see how they were getting on-he did not stay long, however, for a slight noise from the observation post caused him to dash off instantly, although his mate maintained her usual unconcern. In fact, by this time the female had become so accustomed to the observation post and the noises which proceeded from it, that I found it difficult to scare her away when I wanted to make my exit, or when I wished to secure moving pictures of her leaving the nest. I tried pulling the branches at the end of the rope right up to my hiding-place ; then I clapped my hands and even shouted, without causing her the least uneasiness. Once I dropped my hat to see if I could induce her to leave-but again without result.

When at last I heard my companion's whistle from the footpath amongst the trees, I decided that this should be my opportunity for getting the pictures as she went off at his approach. So as he drew nearer I commenced to turn the handle, and shouted to him to 'put her off.' For some time she remained standing motionless on the side of the nest, and not until my friend had violently shaken a small elder bush did she at last leave.

A week later, that is July 7 , I watched the young hawks preparing to leave, and actually leaving, the nest. They were now pretty well covered by their brownish feathers, although a good deal of down was still adhering to their bodies. They were, strangely enough, all males.

They seemed anxious to attempt a trial flight, but as yet seemed to lack confidence, for every now and then one of them would stand on the extreme edge of the nest, lean forward and raise his wings above his back, as though about to take the plunge, and then, thinking better of it, would turn round and spend some seconds in jumping into the air, and flapping wildly with his wings as though giving vent to his pent-up feelings.

At last, however, one of them took the fatal leap, and flew with extraordinary ease to a branch some 10 or $\mathbf{1 2}$ feet from the nest, where he sat preening himself more intently than ever.

And soon another followed him, and then another; the one remaining youngster contenting himself by continually repeating the upward jumping and wing-flapping exercise. Some time later the old female returned to the nest with a headless starling in her talons. I am inclined to think that she had caught this herself; for it was bigger than the mate's usual prey; also, she had not been with the young for some hours; and I did not hear the call of the male before she appeared on the nest. 
The single young one on the nest set up a plaintive mewing when he saw her approaching, which was taken up by the other three in the branches. Ignoring the absence of three of her family, the mother commenced to tear the victim to pieces, and seemed quite happy when the solitary youngster took from her beak and swallowed the little bits that she gave to him.

But in the meantime the mewings of the three young ones in the branches were growing more and more insistent, until one by one they returned and shared in the meal. I noticed that before plucking up courage to fly the tone of their mewing grew higher and higher pitched, and was at the moment of taking off exceedingly shrill and very quickly repeated.

On the following day all four of the young hawks were sitting among the branches, though they would frequently return to the nest to lie down and take a rest. They always greeted the arrival of their parent with an outburst of mewing, and as they gained confidence in their wings, they returned the more readily to her side.

For yet another week the young hawks returned to the nest for food, although by that time they were experts on the wing, and one might imagine would have found their way further afield.

On July 15 an unplucked and intact Great Tit was lying on the nestthe first bird that I had seen there which had not been plucked. It is possible, since the young hawks must sooner or later acquire the habit of plucking their quarry for themselves, that the parents at this stage purposely bring intact birds to the nest in order to encourage them to make a start.

Whether either of the young hawks succeeded in plucking it I cannot say, for when one of them came to the nest he merely snatched it up and carried it away, fearful no doubt lest the others should claim a share.

And so my experience with the Sparrow Hawk family came to an end-I did hear of them being fed on the ground some days later, but on trying to approach the place only succeeded in catching a glimpse of their vanishing forms as they flashed away through the trees.

It may be gathered from the foregoing that the Sparrow Hawk, as well as being a highly temperamental creature, is also extremely courageous. But in order to prove perhaps more conclusively that such really is the case, the following incident, for the truth of which I can personally vouch, may be of interest:-

A sitting female Sparrow Hawk was approached one evening by a man with a gun, who was out to end her life. As she left the nest he fired both barrels at her, but, apparently, only succeeded in dislodging a bunch of feathers.

On the following day he again went to the nest, but seeing no sign of her, imagined that she had either left the place in terror or had dropped among the trees to die. 
So he decided to climb up to the nest, and take any eggs there might be for his son's collection.

On looking over the edge of the nest, he was surprised to see that the Sparrow Hawk was back on her eggs. She was dead. 


\section{CHAPTER XII}

\section{The Home Life of the Heron}

$I^{\prime}$

N the romantic age, when Falconry was the sport of Kings, a deep interest was taken in the Heron, for the reason that in those days it was the quarry de luxe of the lordly Peregrine; and to interfere with a Heron or its nest involved risks of the most painful punishment the law could inflict, so anxious were the authorities to preserve the birds for their favourite sport.

And even in these days of hammerless ejectors and split cane rods, one cannot but recognize in the Heron a bird so beautiful in form and colour-so decorative, that even the most enthusiastic trout-stream owner would, one imagines, be sorry to find it completely exterminated.

It is generally the ambition of every aspiring naturalist photographer to obtain a successful picture of the nest and eggs of some particularly rare or attractive bird-a comparatively simple matter when the nest is on the ground or in a bush, but an exceedingly trying one when, as in the case of the Heron, the nest is in the top of some apparently inaccessible tree.

A photograph of a Heron's nest and eggs was the result of the writer's earliest attempt at serious tree-top photography: and strangely enoughprobably more by good luck than judgment-it proved to be so pleasing as regards composition, lighting, and so on, as to subsequently create such a favourable impression upon a certain photographic critic of the day that the author was encouraged to carry on with his interesting, if at times risky, diversion.

It was secured after a most unhappy two hours had been spent in climbing the tree, and in attempting to fix in position the little camera in which such implicit confidence had been placed. And then, of course, the business of focusing, readjusting and so on had to be gone through, the unsteadiness of the camera rectified, and the dark-slide ultimately placed in position. At the psychological moment a misty rain began to fall, and the writer, who had read in the photographic handbooks that in order to take good photographs one must have the sun shining over the left shoulder, felt his heart sink to the region of his boots.

Had he thought as he thinks now, he would certainly have welcomed this 
veil of mist, for with luck it might impart the atmosphere of height and mystery, which would seem to be so desirable in such a case.

Since that day it has fallen to his lot to spend many hours amongst the Herons' nests, and to have had ample opportunity of observing and photographing not only their sky-blue eggs in varying lights, but the birds themselves, their manner of brooding; of feeding the young; a nd of disgorging their food.

It perhaps goes without saying that, in order to become thus acquainted with such an arboreal family, it is necessary to construct an observation post on the same lines as that which we made when studying the Rook, into which, in due course, the observer may retire, and whence he can watch events without himself being seen.

The building of the observation post will probably extend over a period of weeks, for the Heron, like the Rook, is an exceedingly shy bird, and if so huge a structure were to appear too suddenly, the result would probably be that the family under observation would be deserted.

However, the construction of the observation post has been dealt with more fully in previous chapters, and for the purpose of the moment we will suppose that we have an observation post already prepared at the top of an oak tree, and within a few yards of several Herons' nests ; that it is about 8.30 on a July morning; and that we are on the way to the Heronry.

The day is sunny and still ; hardly a breath of air stirs among the trees, and the place seems uncannily quiet.

It is always so towards the end of July. One hears little of the bird voices of early summer, except perhaps the song of the ubiquitous wood-pigeon, who does his best to coo a love song from the hawthorns in the valley.

Through the dead leaves and undergrowth on the way to the Heronry a little pathway has been cleared, so that it is possible to creep along to the trees in comparative silence, and at least without the upsetting accompaniment of snapping twigs. At a bend in the path a halt is made, for away up through the branches one of the Heron's nests may be seen, and standing upon it, silhouetted against the sky, four nearly full grown young Herons. What extraordinarily beautiful birds they look-even at such a distance. A few yards further on, and still under cover, we are at the foot of a tree, in the topmost branches of which the observation post, well camouflaged with dead branches, looks for all the world like an enormous inverted wren's nest.

Close by it are two more nests : one containing eggs, and the other halfgrown young ones, and by peering through the foliage one can see that an old Heron is on each of them. Only the head and neck of the one with the eggs can be seen, as she is sitting; but the other is standing on the edge of her nest preening herself. What a magnificent bird! One feels inclined to stand and watch her indefinitely. 


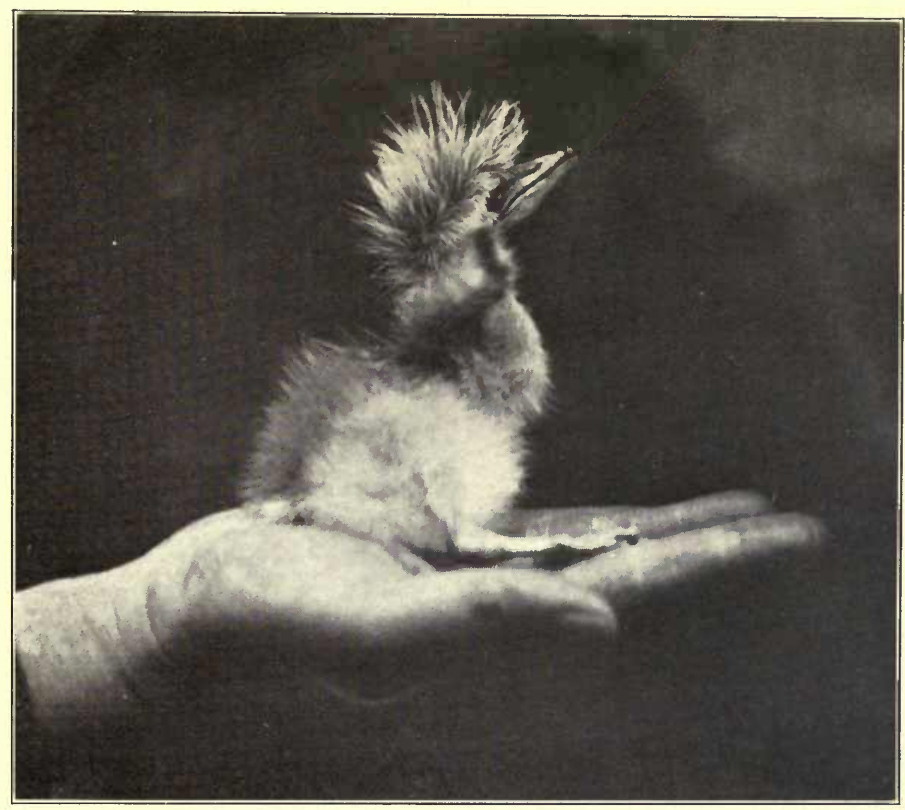

A YOUNG HERON JUST HATCHED

A

HERON'S

NEST

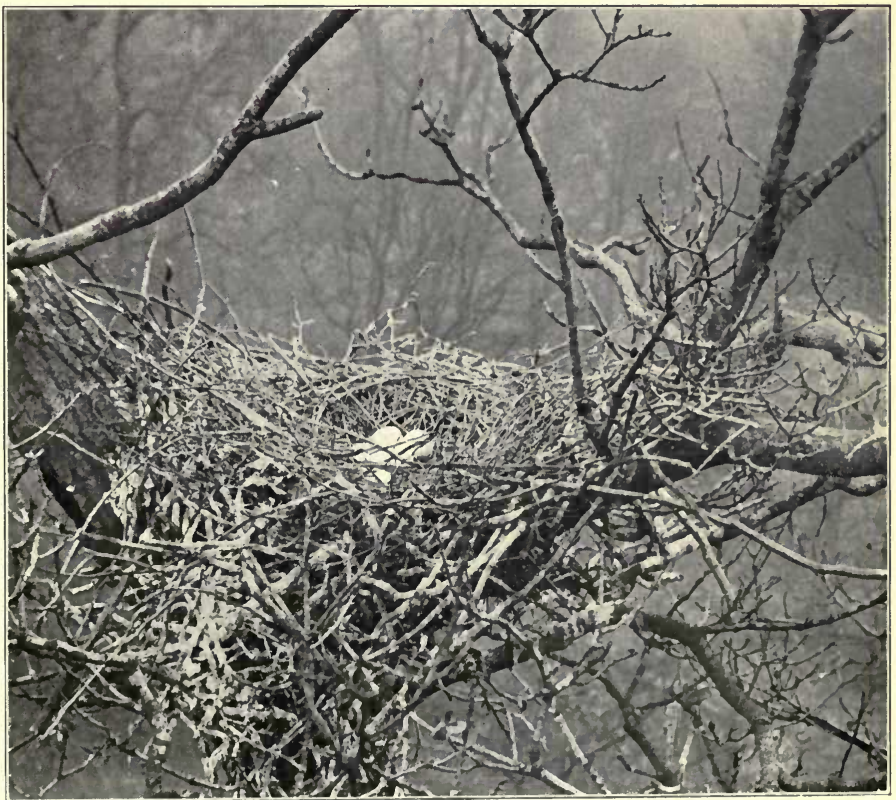



But if the Herons are to be seen at really close quarters it is perhaps waste of time to spy at them from this distance and elevation, and we may as well proceed without further delay with the business of climbing to the observation post, and with this end in view we step into the open from our overhead cover.

Immediately the whole wood is in an uproar! Herons ' fraanking' with resentment, flop from their nests above, whilst some, bolder than the others, wait still as stone upon the edge of their nests before joining the dark soaring forms gathering in the air above the trees.

Glancing up at the nest with the four large young ones we notice that it now seems to be empty, and we wonder whether they too have attempted to follow their older relations into the sky!

The tree-an oak-is somewhat difficult of ascension, for it lacks any helping branches for the first 20 feet or so, and for this distance one has to work one's way up in much the same manner as one climbs a rope in the gymnasium.

At last the observation post is reached, and before creeping into its interior, we notice, as we cast a glance at the nearest Heron's nest, that the four young ones which we had thought might have taken flight, are crouching on the floor of it.

Inside the observation post is a more or less horizontal branch, which serves as a seat, and after the exertion of climbing the tree, one sinks on to it with feelings of deep thankfulness for its timely presence.

It is a mistake, however, to be too optimistic under such conditions, for we may be sure that long before even an hour has passed, the seat will become painfully uncomfortable, and we can only hope that, when a change of position becomes essential, our movements will not frighten any of the old Herons, which may, by that time, have returned to their nests.

Peeping through a little spy-hole, which has already been prepared, we notice that the four young Herons are still crouching-so absolutely motionless are they that one has to gaze at them for quite a considerable time before being able to make out which sleek head belongs to which body; or to decide exactly how many staring yellow eyes there are among the compact mass.

For thirty or forty minutes they remain thus inert, and one begins to wonder if they will ever come back to life. Then without any warning, one of them, hoping no doubt that the danger has at length passed, raises himself on to his knees-or elbows-and turning his head half-sideways, fixes his gaze upon a large semi-digested fish, probably weighing over $2 \mathrm{lb}$., which one of the other members of the family had disgorged at the approach of seeming danger.

Anxious, no doubt, not to lose such a golden opportunity, he hesitates no longer : his head shoots forward, and he seizes the tempting morsel with the tip of his beak. The process of swallowing it seems to cause him considerable 
anxiety and trouble; but with a series of the most energetic jerks, accompanied by a strained expression and bulging eyes, he eventually succeeds in his task : the shape of the fish being seen for the last time as it passes down the interior of his slender neck.

A few words apropos of this peculiarity of regurgitation by young herons may not be out of place here. What prompts them thus to lose their food to no advantage? Surely it cannot be that the feeling of fear which overcomes them is so violent that it literally sickens them.

The writer is of the opinion that it is due to an instinctive desire to lighten themselves in case of an emergency flight-and for two reasons. Firstly, it seems that young herons do not disgorge food from fright until they are approaching the age at which they will become 'branchers,' that is to say, will be sufficiently developed to take short flights to neighbouring branches.

And secondly, it is a fact well known to Falconers that a Heron ' ringing up' (rising in the air) before a couple of Falcons, will, in its efforts to lighten itself, and so keep above its pursuers, disgorge any food which may still be undigested. So that in watching such a flight one might expect to see a small shower of-for instance-fish and shrimps fall from the clouds.

But this habit will be referred to later, and to return to the nest under discussion, we see that the four young herons, having now sufficiently recovered from the shock of seeing a human being, are all standing upright upon the nest, preening their feathers and stretching their beautiful grey wings.

One of them suffering apparently from some scalp irritation, stands upon one foot, and for some half a minute scratches the top of his head with the middle toe of the other. They are very busy fitting themselves for the life that lies before them.

Through another peephole-a little more to the right-we can see the nest which contains eggs, and also the female parent Heron, which in the meantime has returned to her charges.

She is sitting quite flat, so that the top of her back is only slightly above the level of the edge of the nest, and with her head wedged back between her shoulders.

What a piercing yellow eye she has! So round it is, and so severely does it seem to fasten its gaze into the very depths of the peephole, that one feels quite embarrassed at being thus found out whilst playing 'Peeping Tom.' As a matter of fact this is the Heron's normal expression-it reminds one somehow of the glassy stare of a snake.

Occasionally she raises her head-but without the least movement of any other part of her body-to satisfy herself that a blackbird or rabbit scrabbling about in the leaves below is really nothing to occasion alarm.

To see her head return to its position between the shoulders is indeed a 


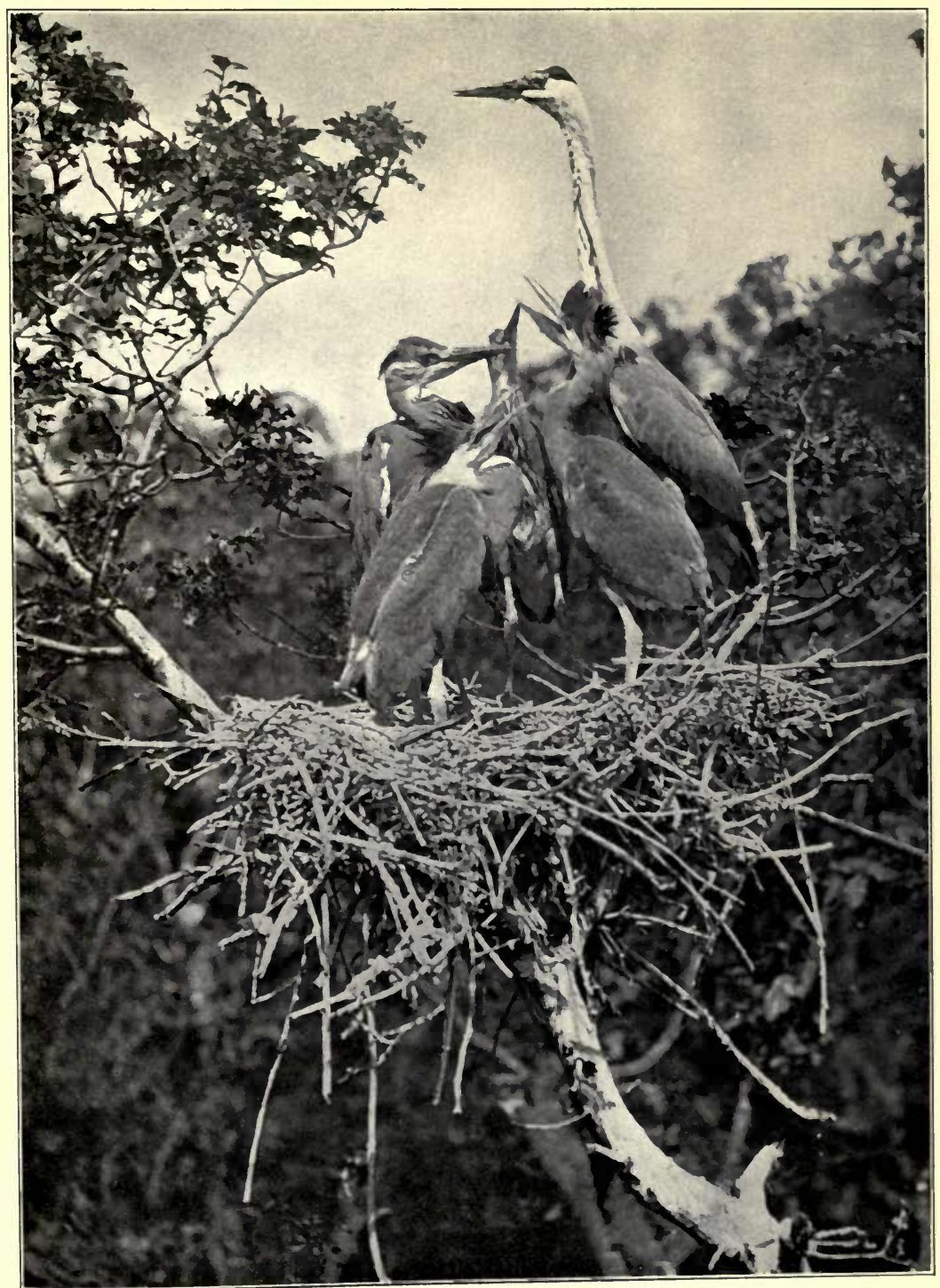

WITH HER YELLOW EYE FIXED ON THE O.P. 

revelation; so gradually, so almost imperceptibly does it subside, that it is only by watching its position in relation to some twig which is really stationary that one realizes the fact that it is moving at all.

But how exceedingly uncomfortable the seat is becoming! A change of position is clearly indicated-and that without delay; already one foot has ' gone to sleep,' whilst the other, owing to its being wedged into a fork of the tree, has developed a species of cramp. So by stealthily clutching an overhead branch the body is gently raised a few inches forward, and lowered again with as little to do as possible. What a relief! But a good idea would surely be to make a cushion of a sack which is hanging from a branch supporting the roof of the observation post, and seems to be serving no useful purpose in its present position.

So the sack is quietly taken down, folded into the semblance of a cushion, and placed upon the "seat branch'; the body in turn is again raised and lowered, this time on to the yielding sack.

This of course is much more comfortable-a splendid idea-and being a little higher one can look with less inconvenience through the various peepholes. Particularly well, can the nest on the left-that containing the halfgrown young ones-be seen.

These youngsters are the most extraordinary little creatures. A good deal of the 'down of youth' (if the yellowish feathery effect may be called ' down') is still adhering to their bodies-and that, combined with their growing feathers, which seem to be pushing through at most awkward angles, gives them a shaggy, unkempt appearance, which borders on the ridiculous.

This unsophisticated family, not yet having reached the age when fear of apparent enemies induces them to crouch, or disgorge food, lead a happy care-free life, and at the moment seem to be wondering what to do next. One of them gazes for some time into his ibrother's motionless face, and then pecks thoughtfully at the yellow eye. This act of friendship seems to be misunderstood, for a squabble ensues-the two of them sinking into a sitting position, and pecking wildly in the direction of each other's faces.

First one, as it were 'throwing' his head at the other, leads off : the blow misses its mark by several inches, and the opponent seizing his opportunity, retaliates in the same manner. He too fails to score a hit, and the first, having in the meantime assumed the correct attitude of aggression, once more tries his luck-again without success.

Soon they are at it hammer and tongs, squawking and squealing in the heat of battle. Really they look very much more like two figures fighting in a Punch and Judy show than two junior members of a most dignified race of birds. One wonders how they would settle the difference if their parent should unexpectedly return to feed them!

But no mature bird-with the exception of the one sitting on the right- 
has yct put in an appearance. She is as motionless as ever-her cold yellow eye still-apparently-fixed on the peephole.

Well, it is an opportunity for another change of position, so the body is raised as on the previous occasion.

In an instant the sitting Heron's head has shot up to the full length of her neck-for a fraction of a second it is held so; clean cut in form, and with eye rounded in terror-then a 'whoof-whoof' of her great wings and-she is gone! Almost immediately the 'flop' of something hitting the ground below reminds us that we had omitted to fasten the cushion-sack on to our seat! Hence the Heron's consternation.

So once more the hard branch-minus the cushion-is utilized as a seat; and it would seem lucky that the sack dropped when it did, for a few minutes later the half-grown young ones-their quarrel forgotten-suddenly develop a state of the most feverish excitement. With crests and 'hackles' raised, they stamp about the nest, uttering the while a queer 'chun-chun-chun'-not unlike the noise that a steam-roller makes-and trying, it almost seems, to brush each other aside with their ' quilly' half-spread wings. In a few seconds the cause of their excitement appears, for with his great wings beating the air as he steadies his flight, the most glorious male Heron lands upon the edge of the nest.

The young ones, now quite overcome by their excitement and unable to contain themselves any longer, begin to bob up and down before him, curtsying as it were, in their anxiety for the food which they cannot see, but which they conclude will be produced.

'Food which they cannot see,' and food moreover which the observer would not even suspect-for the Heron does not, as is sometimes erroneously believed-carry its food in a pouch at the base of the bill as a Rook does-nor in fact anywhere else where its presence might be detected. The food is swallowed, and then disgorged for the young, and is usually more or less digested.

The actual process of regurgitation covers a period of several minutes. In the first place the parent Heron raises his head to the full extent of his slender neck, and with convulsive workings of his cheeks and throat prepares to eject the meal.

This secms to tantalize the young ones to such an extent that their steamroller cry gives place to a noisy pig-like squealing, while, reaching up unsteadily on their immature legs, they make wild jabs with their beaks in the direction of their parent's face.

Then, quite deliberately, the provident head is lowered, so that the young herons may, commencing at the extreme base of the bill-and sometimes about the region of the eyes-draw their beaks along his to the tip-in much the same way as one milks a cow-and by so doing, scrape off some semi-fluid substance which seems to give them great satisfaction. 
Then again his head is raised; more convulsions of the throat and cheeks follow, whilst the youngsters, squealing with undiminished energy, seize and scrape his lowered beak as before.

At length, having raised and lowered his head some seven or eight times, he ultimately, in spite of the frantic efforts of the family to seize any unoccupied portion of his bill, succeeds in disgorging into the nest what may be described as the 'main meal,' consisting of partially digested eels, and, apparently, some of the usual crustaceans.

The young ones gobble up this mass in an extraordinarily short time, and then, their interest in their parent having temporarily abated, amuse themselves by silently searching for unnoticed trifles amongst the crevices of the nest.

Meanwhile their parent, well satisfied it would seem, with the progress of the family, stands contentedly on the edge of the nest, blinking his eyes, and making from time to time the characteristic 'clop,' which he does by closing his beak with a snap.

Then, having shaken himself heartily, he turns his head towards the marshes, spreads his great wings and sails away.

A commotion on the right suggests that a Heron has just alighted, and turning to the right-hand peephole, we peer through to see that the female Heron with the eggs in her nest has again returned, and is standing on her threshold having a last look round before settling down; probably half expecting to see another sack fall from the observation post!

However, things seem normal, and she steps gracefully forward, and, bending her legs, sinks gently down into the nest. Then once more the yellow eye is fixed-at least so it seems-upon the little peephole.

Here it may perhaps be mentioned that there exists to-day in many parts of the country a common belief that the Heron constructs its nest with a couple of holes through which the legs of the sitting bird may be allowed to hang. The writer has sometimes ventured to question this theory with some of its followers, but to no purpose ; for the argument is finally settled by their remarking that the birds must build their nests in this way, or they would be unable, on account of their long legs, to sit at all !

About an hour after the male has fed and left the nest of half-grown young ones, the female comes to feed them. One knows some few seconds before she reaches the nest that one or other of the parent birds is about to arrive, for the young ones begin their bobbing movements and the curious 'chun-chun' noise.

When she at length pitches on the side of the nest, we are indeed amazed to see a bird so badly turned out at this time of the year. With wet head and neck-evidently from a very recent immersion in water-and lacking the beautiful black plumes at the back of the head, she really reminds one very much of 
the stuffed specimens which were once so popular in village inns. Her plumage too is of a uniform greyish colour-very different from the splendid greys, whites and blacks of the male.

But at least she provides a most interesting entertainment, so we must not be too critical.

Having gone through the usual throat-working and beak-stroking preliminaries, she lowers her head for the last time, and to the joyful shrieks of her family, disgorges an enormous eel partially digested at the head end, which falls a shiny, inert mass on to the nest.

On this the youngsters fall like a little pack of wolves, pecking off and swallowing small pieces from the most convenient parts : each one working his hardest to secure the lion's share before it is too late. Ultimately one of them seizes the body of the eel in his beak, and by a series of rapid forward jerks of his head, attempts to work it down his throat-but the eel is altogether too bulky, and the young heron, in despair, drops it again on to the nest, whence it is immediately snatched up by another young heron who, in turn, tries his utmost to dispose of it.

Not yet willing to give in, and yet thoroughly exhausted by his efforts, this young heron is forced to rest, or to have a 'breather' at least; and overbalanced by the weight of the eel, he does so whilst propped up by the tip of his beak, which is pressed on to the nest!

However, none of them are able to manage the eel, so the patient mother (one imagines with a sigh of resignation) once more picks it up, swallows it, and retires to some tree near by, where time may have an opportunity of doing the work of partial digestion. After about an hour she once more returns to the nest, is greeted in the same fashion as before, and produces the same eel (considerably smaller this time), and seems much relieved when one of the youngsters, after a good deal of effort, manages to swallow it.

In the meantime the four large young herons on the nest nearest to our observation post, have spent their time in preening themselves, exercising their wings, and watching the goings on in other nests, but have never become in the least excited, and seemingly take no notice of the herons overhead.

Suddenly, however, a change comes over them. With wide-open eyes, raised crests and beaks pointing skywards, they gaze above them. Slowly their beaks move sideways, and again upwards, obviously following the flight of an approaching Heron.

It seems incredible that they can be able to distinguish their parents from the scores of herons which daily pass above them, and yet on this occasion they have certainly made no mistake, for within a few seconds, welcomed by the squawkings and curtsyings of the family, a beautiful female Heron alights beside them.

Now it is interesting to note how very much more vigorously these almost 


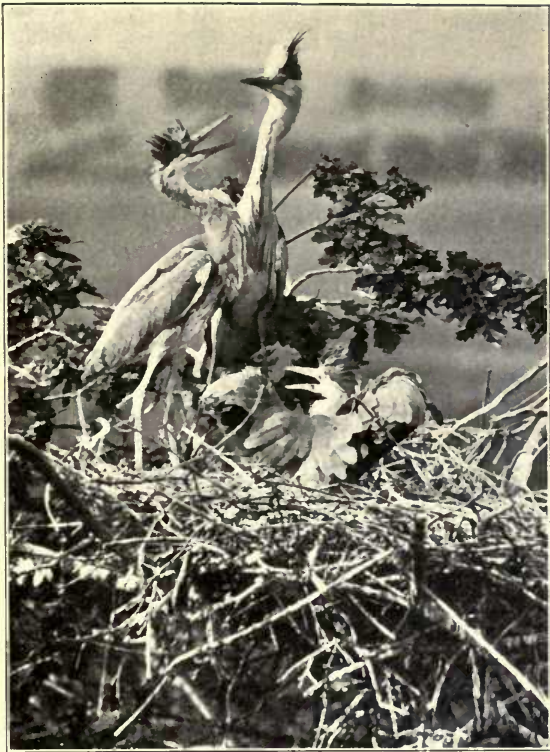

(1) The young herons noisily acclaim the arrival of their parent, and

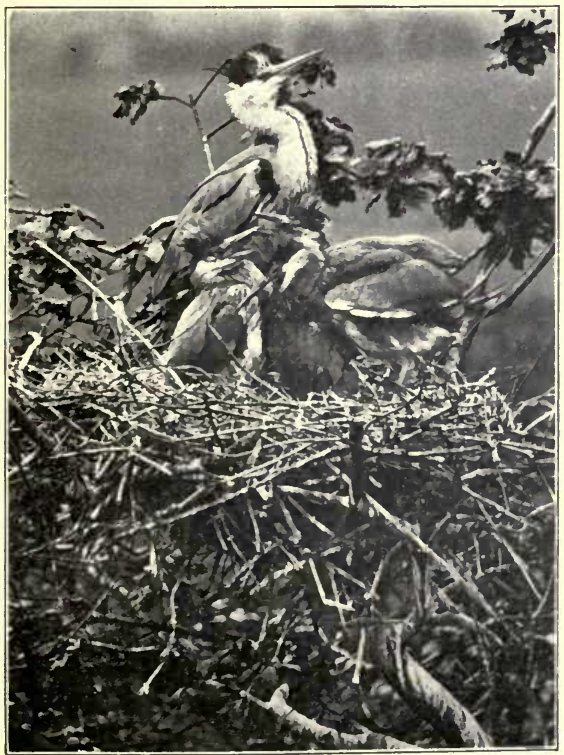

(3) Having fought over, and swallowed the nnsavoury-looking mass.

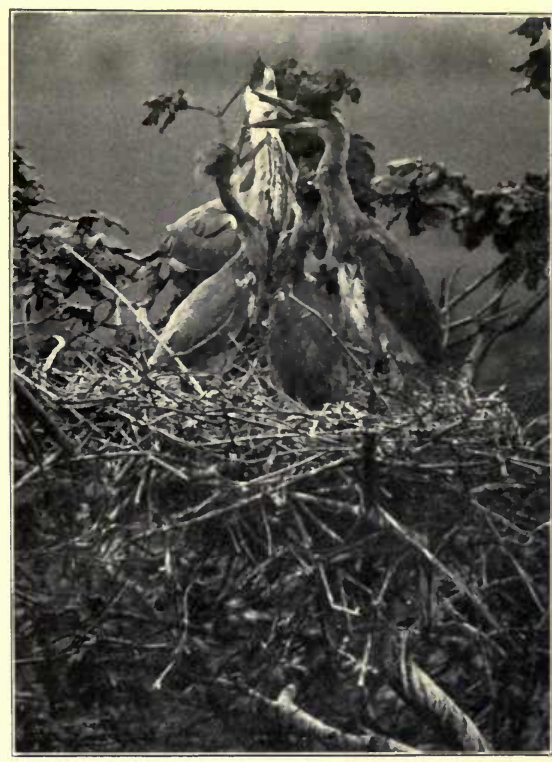

(2) by "stroking" her beak endeavour to induce her to disgorge.

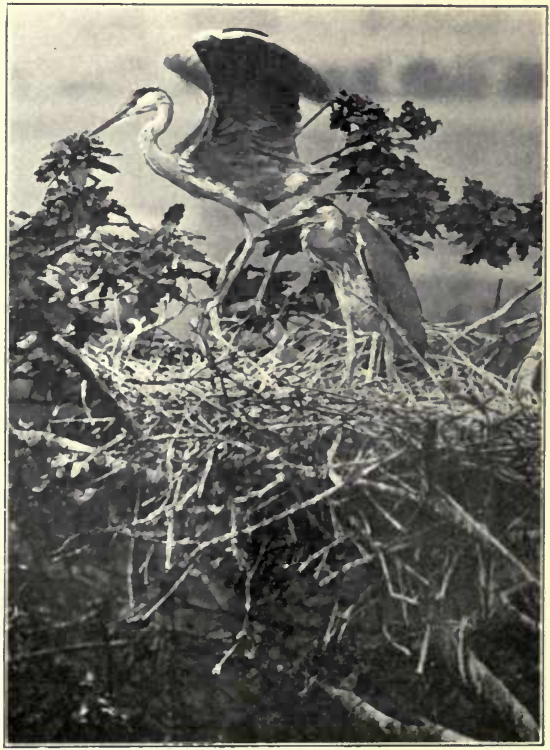

(4) J'hey, one by one, adjourn to the neighbouring tree tops. 

fully fledged young herons endeavour to hurry the process of regurgitation. Almost before the bird has time to steady herself, one of them, reaching up to her high-held head, and literally snatching her beak in his, attempts to drag her head downwards towards the nest.

As he loosens his hold, another, making a rather wild shot, seizes her head -at about the region of the eyes-in his beak, and almost topples the patient creature backwards over the edge of the nest in his endeavours to induce her to disgorge.

There is no waiting now for the beak to be lowered before it is seized by one or other of the young ones. At whatever elevation her head is held, one of them makes a grab, and seizing her somewhere near the base of the beak, literally forces her head down towards the nest.

Whether or no the parent bird welcomes this noisy demonstration, as proving that the family is healthy and gaining in strength, it is impossible to say. She certainly seems not to resent this rough behaviour, and in the endas in the case of the other bird-disgorges a mass of food on to the nest, the various ingredients of which the young herons do not have the least difficulty in swallowing; unless of course it should be snatched from the very mouth of one by another, or is seized by two of them at the same moment, when a lively struggle for complete ownership ensues.

At all events, the food is quickly disposed of. The old heron soon makes her departure, and the young ones, having collected any remains from the floor of the nest, prepare to take life comfortably for a while. The writer has noticed that whilst the young herons are quite small-and when first hatched they are not naked, but are protected by a shaggy greyish-coloured coat-they are fed frequently throughout the day on digested food which is taken in a semiliquid state from the tip of the parent heron's beak-and that at this period one or other of the old herons is generally on the nest, either brooding the young or standing by their side.

But as the family develops the visits of the parents become less frequent, and when they do occur, are of much shorter duration.

Since, in order to witness the foregoing incidents, a very considerable time has been spent in the observation post, and in spite of frequent changes of position, we have found our branch seat and limited quarters increasingly uncomfortable, we now decide, with cramped muscles and aching back, to return to earth.

Hanging from the observation post to the ground is a thin line-and tied to the end of it a collection of tin cans, slates, and branches-all in readiness to jangle and clang when the observer jerks the string.

For it perhaps goes without saying that suddenly to appear from the observation post when the time for retiring comes round-and when perhaps one, two or three old herons may be on their nests only some 20 feet away- 
would perhaps lead to one, or all of them dashing off in consternation, and being so terrified as to never return.

So, in order to safeguard against this dreadful possibility, the contrivance at the end of the string has been arranged, and before beginning to descend the tree, it is necessary to continue to jerk the string until all the mature herons leave the vicinity.

At the first clatter from below the Heron with the eggs instantly raises her head-for a few seconds she remains motionless, perhaps undecided whether to leave or stay-but as the sound increases in vehemence, she ultimately rises to her feet, stands for a few seconds in bold relief against the distant treetops, then lowering her head, she spreads her wings, and aided by a vigorous 'push off,' swings away out of sight.

*

$*$

$*$

*

How unsteadily one stands when on earth once again! However, it is a small and temporary price to pay for such an interesting experience.

Before closing this chapter, something ought to be said regarding the food upon which herons normally subsist.

It is generally impossible to tell even from the distance of a few feet, exactly what the parent heron disgorges for the family-amid such confusion one cannot hope to see more than the form of some shining object as it is vigorously jerked down its captor's throat.

On one occasion, however, during the present summer, the writer was watching, and photographing, a female heron feeding her young-when he noticed that one of the youngsters had got into difficulties. In its efforts to secure a good share of the meal, it had contrived to get its neck encircled by the body of a large and very long eel, whose head was already some few inches down the heron's throat.

There was no question about this particular item of the meal, particularly as, since it had become stuck to the young heron's neck feathers, there was plenty of time to identify it!

But as a general rule, the simplest, as well as-may we say?-the most humane method of determining the Heron's normal food, is to examine whatever food may be disgorged by the larger young ones.

If one should climb up to a heron's nest in which there should chance to be a family of well-grown youngsters, one-or all-of them is practically certain to disgorge food, possibly for the reason already suggested.

In consequence of this unique habit, it is a good plan to wear the oldest possible clothes when such a calamity is possible (an umbrella has been suggested !) for although the food is often disgorged on to the nest (and later swallowed again), it is not infrequently distributed overboard, and may very possibly land upon whatever portion of the climber is uppermost. As an 
instance of which I may quote the case of an intimate friend of mine, who, having climbed-after very considerable difficulty-almost up to a heron's nest, was glancing up to see how much further he had to go, when one of the young herons, disturbed no doubt by the violent shakings of his house, and foreseeing possible danger, decided to lighten himself in case of an emergency flight. Most of the cargo landed on my friend's chest. Half a semi-digested eel and a portion of water rat sliding into the opening of his waistcoat !

But after the young herons have left the nest, and before they leave for the marshes or the mud flats, they spend their days in the tops of the trees in or around the Heronry, and return to the nest to be fed, and it is during this stage that they will disgorge upon the slightest provocation, and it is not at all unusual for them to do so when disturbed merely by the fact of one's walking under the trees in which they are sitting.

At about the end of June, when the tops of the trees about the Heronry are, as it were, dotted with the figures of young herons, the resounding ' flops' as disgorged eel, or fish, or water rat hits the ground, remind one of the sound of ripe fruit dropping in an orchard on a windy day.

If these objects be examined, they will be seen to vary very considerably -eels-big and small there are in plenty, an occasional fish will be found (I have discovered carp, a few flat fish, and once actually the undigested half of a large gold fish), water voles in great numbers; also countless moles, shrimps, and water beetles (the latter of the species known as Dytiscus Marginalis). Also on one occasion, the whole of a quite fresh Redshank-immature but fully fledged-was thrown up, and I have at other times found the feathers of other birds inside the Heron's castings or pellets.

For the Heron, like the Hawks, Owl and Crow tribe, produces castings of the indigestible portions of whatever may have been consumed, and the examination of such castings is further prouf of what the Heron has eaten.

One cannot expect, however, to discover by this means what kinds of fish the Heron has been taking (and perhaps by doing so to prove that he does not take trout !), for his digestive powers enable him to assimilate the bones, scales, and so on of fish, eels, etc., and the castings are generally composed entirely of the fur and claws of water voles (or water rats) and moles, with a few wing cases of Dytiscus Marginalis, and occasional feathers.

Having ultimately become sufficiently strong on the wing, the young herons leave the tree-top world of their youth, and generally go to the marshlands, where they quickly learn to fend for themselves.

On the marshes close to a Heronry in the south-east corner of England, one may frequently see towards the end of June, or during July, as many as forty or fifty full-grown young herons, standing in the middle of a semi-dried marsh, or in the water at the edge of a dyke.

Early in the morning, or towards evening, they may be seen walking in a 
slow stately manner amongst the grass, carefully searching the ground for anything in the way of food.

Suddenly one of them comes to a standstill, and with head lowered and beak almost horizontal with the ground, remains for a short time absolutely still, before striking; instinctively, as it were, assuming the pose that the mature heron adopts whilst hesitating before striking at a fish or eel.

It is an interesting fact that the Heron, with beak held horizontally, is able to look down on to any object beneath it. For since the eyes protrude considerably over the portion of the base of the bill that runs beneath them, and the part of the skull immediately above the eyes rather overhangs, the bird is able to look down with both eyes at an object directly beneath it, whilst it cannot look directly upwards without turning the head on one side.

When the young herons have finally left for the feeding-grounds one can, now that there is no longer fear of scaring them, climb up to one of the nests and examine it at close quarters. Extraordinarily well constructed, it is often -when built up year after year-more than 2 feet deep, and sometimes measures as much as 4 feet across. It is made of quite large sticks-some of them as thick as, and longer than, a soldier's 'swagger stick'-with an inner lining of small twigs, roots, or pieces of dry bracken stems : the whole structure being so strong as to support easily the weight of a human being. 


\section{CHAPTER XIII}

\section{Birds and Artillery Fire}

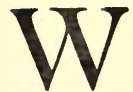

HEN one looks back upon the early days of the war, and remembers the plight of the unfortunate people whose modest homes were situated in what was known as the 'Battle Area,' one is filled with admiration for those who, full of confidence in the Allied Armies, and the belief that help would come at any moment, clung to their homes until the last moment.

I can think of nothing more hopelessly pathetic than the little rooms, littered with half-finished lace-work and children's toys, which had been so suddenly—so tragically-evacuated : and which were so soon to be blown to atoms.

Somehow there seems to be a similarity between the indomitable hopefulness of these people in refusing to leave the places in which their lives had been spent-and the tenacity of the birds of such districts, in clinging, in spite of all, to their ancestral breeding areas. For any of us who were in the firing-line for any length of time during those fateful days, and who chanced to take an interest in wild creatures, will remember that the din of a bombardment, or the crackle of rifle fire, had little effect on the birds of the neighbourhood, and that it was rather owing to the ultimate lack of cover that they betook themselves to more peaceful quarters.

How uncanny it seemed, in the spring of 1915, to hear the Golden Oriole calling cheerfully-almost defiantly-from the top of a shattered tree standing amidst the ruins of what had once been Hooge Château ; or to listen to the song of the nightingale on those summer evenings, and to mark how it grew in vehemence as the whine and crash of 'whiz-bang' and ' heavy' grew in intensity.

And then the swallows and their nests in the smashed barns on the outskirts of St. Eloi : the magpies at Kemmel, and a host of others. None of them breed in those places now. No oak-tree remains to conceal, with its verdant foliage, the suspended nest of the Golden Oriole, or the glorious colouring of the bird itself.

Deep under the fouled earth are buried the rafters on which the swallows 
nested : and only such birds as the partridge and the lark-fortunate under such conditions in being supplied with ample cover in the shape of bushes and grasses - continue to frequent the land as they did in happier days.

Those are strange days to think of now-but days with, after all, certain redeeming features, and days that $\mathbf{I}$, for one, shall not easily forget.

In my capacity as ' sniper' I perhaps had unusual opportunities of noting and observing the various birds with which the firing-line abounded, and on one occasion at least, the chance of inspecting at close quarters a nest which I had never seen before.

We had started out for the day-May 31, 1915-just before dawn, and as usual had stopped at a little pond just behind our firing-line, where we invariably had the only wash of the day, before proceeding on our journey.

Even the pond and its vicinity was full of life-a hare started from under our feet as we approached it, and a little further on a brace of partridges rose with a whirr of wings.

It was a wonderfully quiet morning; and the pond looked extraordinarily beautiful in the first light of dawn. On one side of it was a grand old hawthorn bush, whose drooping branches gently touched the water; whilst in the centre was a tiny grass-covered island supporting an old willow-tree, at whose foot was a moorhen's nest containing egg-shells that suggested tiny moorhens recently hatched. This little family seemed to be doing well, for we saw them later on, paddling along in the wake of their mother, who proudly, and with flirting tail, led the way. Sometimes too, they might be seen pecking about amongst the rushes at the further side of the pond, or clambering out of the water to rest awhile on the little island.

In the hawthorn bush a pigeon was sitting on a couple of eggs; she had quite frightened us a few days before by suddenly dashing out of the bush in that noisy, clattering way that wood-pigeons have!

As it grew lighter we crept forward behind a hedge that was the only available cover, and drew nearer to our destination, which, in fact, was the remains of what had once been a dairy farm. Dead cows, calves, and an occasional pig were lying about everywhere. The farm-house, the dairy, and most of the outbuildings were burnt to the ground; the only building still standing being a cow-shed known as 'Sniper's Barn.'

To reach this cow-shed was our object, and to accomplish it we crawled carefully along the foot of the hedge for some distance, in order to go unseen over a slight ridge before getting on to our feet, and advancing in a crouching position towards the mass of bricks, once forming an outhouse to the farm, which loomed indistinctly before us in the grey light.

At this point it was necessary to pass carefully between the ruins and the hedge on the left; then on over a decomposing cow's body (being careful to hold the breath at this point), until the shell-hole in the wall on the right was 
reached : through this, and across a heap of bricks and mortar to another shellhole which led into the cow-shed.

It was necessary to be extremely careful in getting through this shell-hole into the cow-shed, for through the door on the right the German trenches could be plainly seen, and should the enemy have any reason to believe that the place was occupied they would be certain to shell it.

The further end of the cow-shed was facing the enemy, and it was from here that we endeavoured to fulfil our particular mission. We had two loop-holes in use-one that looked out on to the German lines immediately in front of us, and the other, that we had recently constructed by removing a brick, was so placed that it was possible to see portions of their trenches on our right.

Originally the floor above had been used by the French machine-gunners, as the empty rounds testified, but it could not be used in our time, as the front of it had been blown out by a shell-burst. I went to investigate the position one day, but found that the advantages of the extra height were not very considerable. However, I did find, in addition to the empty rounds, a nest of kittens that were as wild as hawks.

Affixed to one of the beams in our cow-shed was a swallow's nest, shown in one of the illustrations, in which were four or five eggs. The swallow eventually grew quite accustomed to us, and would sit composedly upon her eggs without taking the least notice of any firing that might be going on.

Strange indeed it seemed that in such surroundings all these creatures should be thus living, hunting, rearing their young, and behaving generally as though things were quite normal. A blackbird once actually built her nest in a stack from which a great deal of sniping was done, and even succeeded in hatching her young-only, unfortunately, the enemy shelled the stack and set it on fire.

This particular morning happened to be unusually quiet, and we wondered if such a desirable state of affairs might be accounted for by a relief having taken place in the enemy lines during the night. But the morning mist had not yet cleared, and we could rest assured that we should get plenty of 'strafing' quite soon enough.

I was standing at the left-hand loop-hole, trying to distinguish movement in the enemy's lines, when my attention was attracted by the song of a bird that sounded somehow familiar-and yet I could not place it. Surely I had heard it at home-but-where? Loud and insistent it came in short snatches, lasting only for a couple of seconds or so, and with but a short interval before it was again repeated. It could not be a Missel Thrush, and yet-it was extraordinarily like it. What could it be? Suddenly it dawned upon me that the song was none other than that of the Golden Oriole-a bird I had always hoped to meet at home, but had always failed to locate.

The song came from the direction of a wood on our left, from which a line 
of trees ran towards the German trenches; one could see the line of trees plainly enough through the left-hand loop-hole, though the wood itself was just too far back to be visible. For the first time during my military career my 'bird interest' was really awakened. What feelings that song would have aroused had it been heard in the peaceful woods at home!

Since things were quiet, we decided to try to reach the wood without being seen by the enemy, for my companion, although not having the least interest in birds, was quite enthusiastic at the idea, and we accordingly set out on our journey.

It was, first of all, necessary to return to the pond, whence we could crawl along some old French trenches to the left, and behind a high hedge which led to a pool in the corner of a field behind the wood, from where we could enter the wood without the risk of being seen.

Half an hour later found us creeping through the tall oaks and undergrowth of the wood towards the Golden Oriole, who still continued to pour out his disconnected, though very beautiful, little song.

As we crept forward a nightingale was singing on our left, and a dove noisily left her flimsy nest of twigs, through which two eggs could be seen. Whilst a jay, more perturbed by our presence than by shell-fire, flew shrieking ahead of us. And the Oriole meanwhile sang serenely on.

Yet this wood was shelled every day by the enemy. Several dead cows were lying in the track through it, whilst many of the trees were smashed by the explosions, their branches lying everywhere-torn from the trunk as though by some giant hand; and every now and then a rifie bullet would crack through the branches above.

For a while, though, we had forgotten the war, for our eyes were straining to catch sight of the Oriole's yellow breast, which harmonizes so well with the oak's sunlit foliage.

And at last we saw him-a glorious bird with bright yellow breast, perched on the topmost branch of one of the oaks-and within 10 feet of him the nest-over the edge of which the female's tail was protruding!

Photography of this nest was somewhat awkward, as the tree which had to be climbed in order to get a proper view was not at all conveniently shapedand for part of the journey to its upper branches would be in view of the German lines.

However things might have been a very great deal worse, particularly as, just as we were crawling back to our cow-shed, the Germans started a bombardment of the wood.

We quite frequently encountered various forms of wild life on these expeditions. One day, as we were crawling stealthily along a hedge, a female Sparrow Hawk, in hot pursuit of a thrush, almost dashed into us. Whilst on another occasion we came upon a partridge that had been hit by a stray German bullet 
THE

SNIPING

POSITION

Showing-

THF SWIJIOW'S NEST-
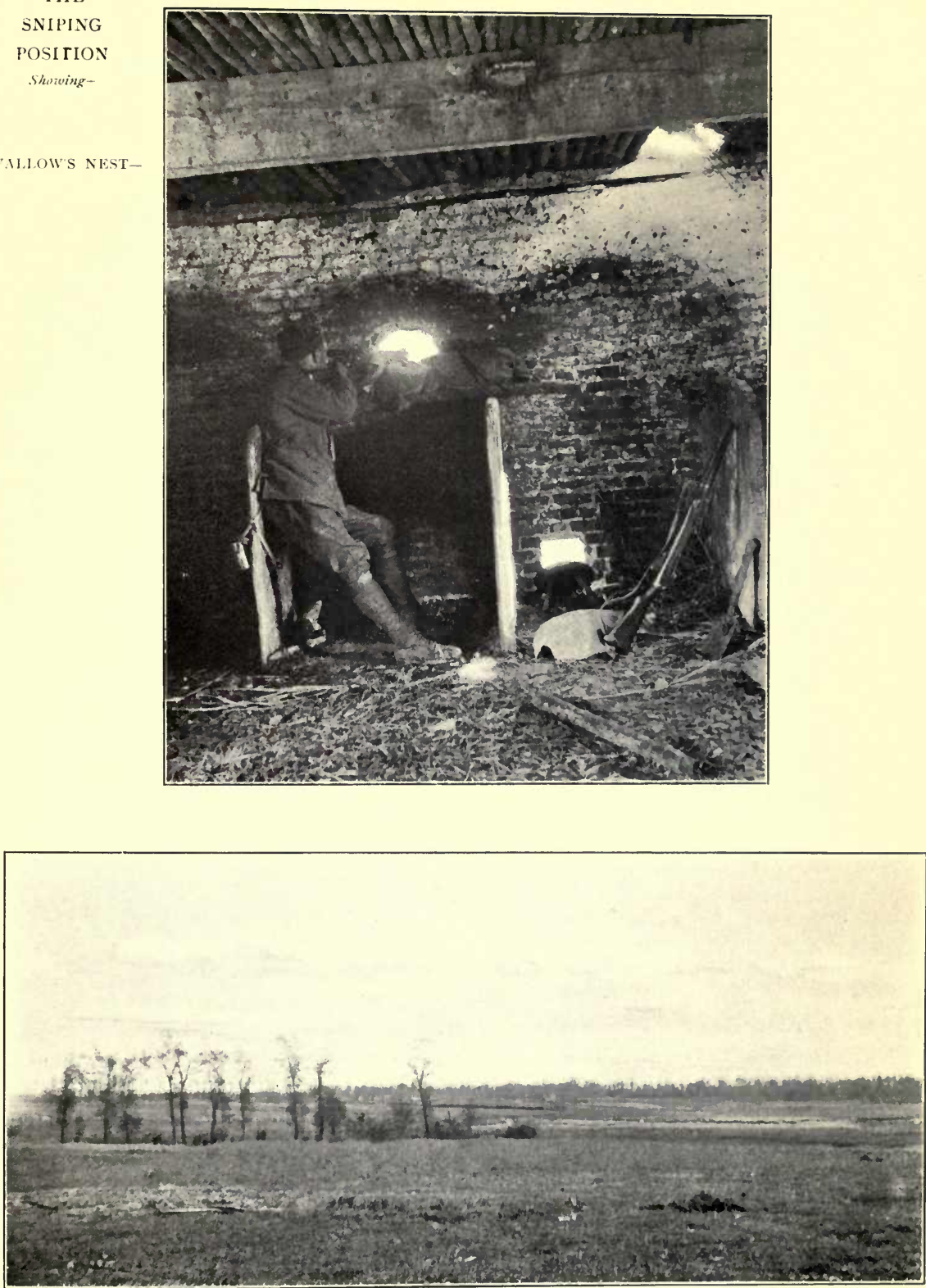

ANI) THE VIEW THROUGII THE LOOPHOLE

(The German trenches may be seen in the middle distance.) 

and I remember at St. Eloi seeing a blackbird drop dead from a tree under which a shell had burst. One wonders how many other creatures suffered the same fate.

Kestrels and Little $\mathrm{Owls}$ were exceedingly common in the firing-line, particularly on the Somme, although I cannot think they nested in that land of unrest-for there were no trees and no buildings that would serve as nestingplaces.

The wily magpie also stuck nobly to his accustomed breeding haunts, and we used to watch a pair of them, not far from the ruins of Ypres, building their nest at the top of a battered tree within 200 yards of our front-line trenches.

Considering that the war was presumably over in the late autumn of 1918 , and that eighteen months later our recollections of its ghastliness had already been partially dimmed, I was perhaps justified, whilst rook-hawking in the wide open spaces of the West of England, in experiencing a kind of minor shock when I suddenly found myself gazing through my glasses at a collection of shell-torn trees that recalled about as vividly as anything could recall in that peaceful spring of 1920, the shattered remains of Thiepval Wood in 1916.

Away over the chalky undulations-so absolutely typical of the Somme country, and silhouetted against an evening sky-the gaunt stems looked curiously silent and deserted. And yet ... could those dark lumps amongst the remaining branches be nests of some kind?

A closer examination showed that, far from being silent and desertedand in spite of heavy Artillery fire two or three days a week-the trees were crowded with busy, noisy life. For on the top of their bare stems, or among their broken limbs, a colony of Rooks, clinging to the accustomed nesting-site with a tenacity that is typical of their race, had placed their nests.

Within 500 yards were undamaged trees in plenty-trees, one would imagine, that could offer every inducement to a pair of matrimonially inclined Rooks-but they were bare of nests.

Oddly enough, some trees, such as one generally finds in the garden, and which, in fact, at one time formed part of the little farmstead that stood on the spot, were positively crammed with Rooks' nests.

It would seem that the Rooks, obeying the homing instinct which is so strongly developed in many birds, preferred to construct their nests amidst the branches of any tree or bush that happened to grow within the favoured area, rather than take advantage of the shelter of tall beeches and pines that were within such easy reach.

For not only were fruit-trees encumbered with the great piles of branches and twigs, but even elder and yew bushes (one cannot dignify them by calling them trees) were similarly utilized.

Certainly this was the most extraordinary Rookery that the writer has yet 
encountered. Some of the nests were so low that their foundations could be touched with the upstretched arm as one stood beneath.

Most of them had been relieved of their eggs by the oologically inclined visitors to the place, or perhaps by the enthusiastic followers of a game known as 'hop-egg.'

In one case some one had taken the trouble to climb up to a nest in an elder bush, and to fill it with half bricks, having first thrown out the unfortunate young Rooks !

The occupants of the taller trees had not, of course, suffered this sort of hostile treatment, though even they had not got through altogether unscathed; for some of the nests had been hit by pieces of flying shrapnel, whilst beneath the trees lay the forms of several dead Rooks. Caught up in the branches at the edge of his nest, a male Rook was hanging. Killed no doubt as he attended to the business of nest-building, or the needs of his sitting mate, his body remained swinging in the breeze-a warning, one would think, to all other Rooks to betake themselves elsewhere.

But so complex is the mentality of the wily Rook that his neighbours persisted in their determination to lay their eggs and rear their young within a few yards of his remains; whilst his mate, quite unruffled by the proximity of her late husband's body, continued to sit closely upon her five eggs.

Photographically, these nests in the taller trees were without doubt by far the most promising. Little or no foliage existed to hide them, or cause those unhappy white and black patches on an otherwise satisfactory print; and, in addition, no loafing troops-hard put to it to invent an amusement for a Sunday afternoon-would be likely to interfere with them; and lastly, with good luck, the camera might be placed at such an elevation as would include a background of the distant downs instead of the sky.

So the writer climbed a suitable-looking, though (since a shell had passed clean through the centre of the stem) somewhat shaky beech-tree, and looked across on to a collection of nests which seemed to offer unusual possibilities from a pictorial point of view.

Photography from this position was not attempted until May 7, and then not until 1 p.m., although the writer had made an early start. For in the meantime he had been treated to an Artillery demonstration-the shells bursting with such accuracy and frequency amongst the trees supporting the Rooks' homes as to suggest that at the termination of the bombardment there would be nothing but débris left.

At length, however, the bombardment died down, and through the clearing smoke the trees once more stood out-apparently none the worse for their shaking.

The writer then learnt that the Battery had finished firing for the day: that the F.O.O. was coming in, and that they were already 'packin up.' 


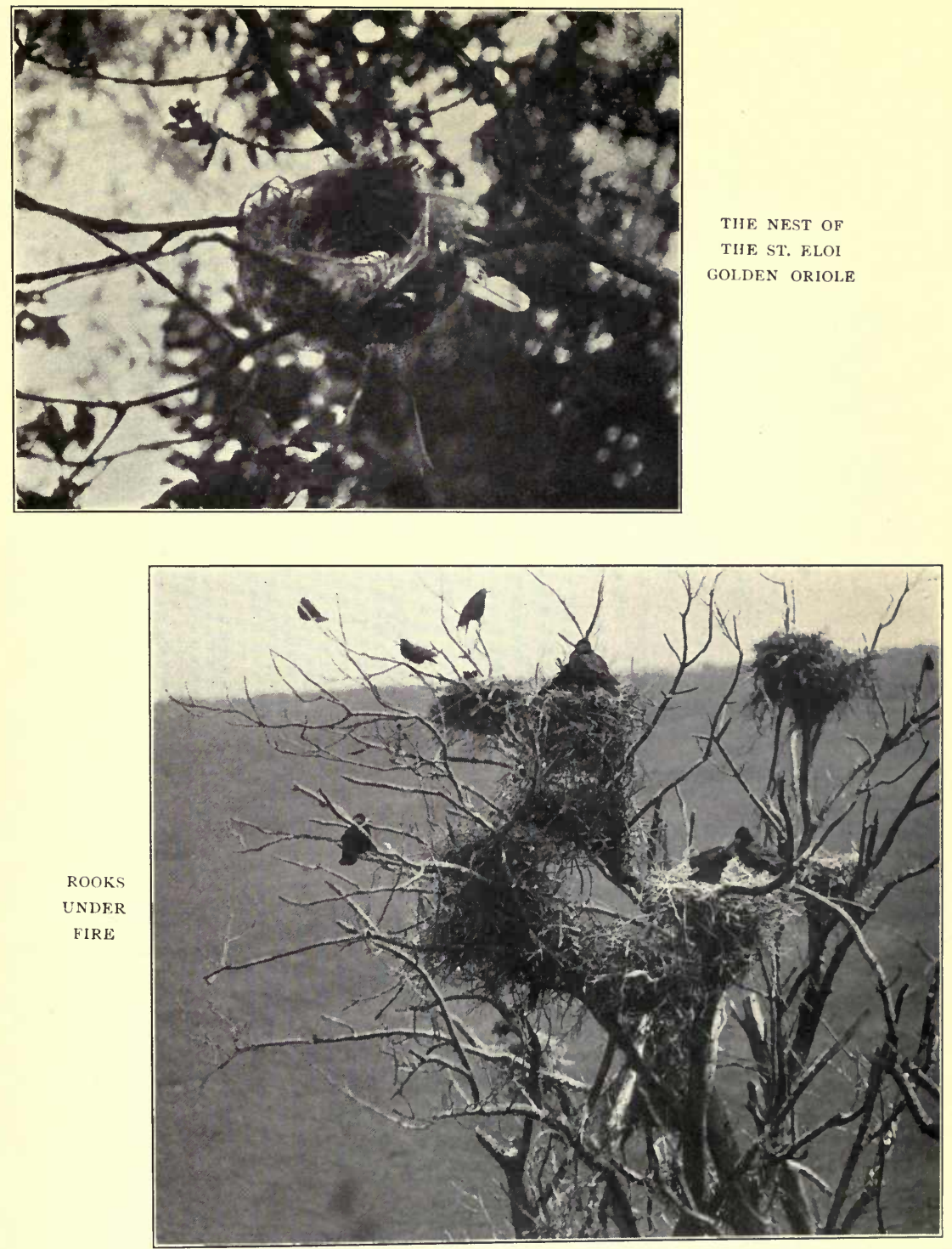



Cheered by the news, the journey towards the Rookery was resumed, and once again visions of the Somme were recalled. The little valley leading to the wood was really exactly like the numerous 'Death Valleys' of France ; whilst the freshly torn earth and pungent smell of H.E. suggested derelict rifles, equipment, and German tin hats.

The trees themselves had suffered little from the recent hammering, though more branches had been torn off, fresh shell splinters were sticking in their sides, and strongly smelling shell-holes had made their appearance amongst their twisted roots. Some two hours later, the camera was fixed in position, and duly focused; the string attached (what a business that is without the help of a companion!), and the dark slide withdrawn in readiness for an exposure.

The writer, not wishing to disturb the Rooks unnecessarily, had decided to retire to a shell-hole for a while before trying for a picture ; and, seated there, was comfortably engaged in partaking of luncheon and watching the Rooks, when he was rudely awakened to the disagreeable realities of life by a most unexpected feeling. This feeling was caused by a dull ' bomp' in the distance, followed by the slow, slithering whine of an approaching ' heavy.'

For a short moment that 'hollow feeling' was experienced; and then the shell, passing away to the left, exploded on an adjacent range with an almighty 'Ber-rang' and the shriek of flying fragments.

All being well, the business of photographing the Rooks proceeded-the results-some of which appear on these pages-showing that the Rooks returned to their nests as though nothing untoward had occurred : that they behaved in fact very much as the birds of France and Belgium behaved before they were literally driven away by the utter devastation of their haunts. 



\section{CHAPTER XIV}

\section{Some Strange Incidents}

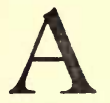

VOLUME of this kind would perhaps be incomplete without some reference to the various phenomena-regarding the habits and under the writer's notice.

For, strangely enough, such deviations from the normal would often seem to be some indication as to whether the creatures involved are capable of exercising actual thought, or whether they merely obey a blind instinct.

Perhaps the most curious ease was that brought to my notice in the spring of 1913, which concerned a pair of Robins and a pair of Pied Wagtails who had co-operated in building, inhabiting, and rearing their young in the same nest. Although it concerns other than tree-nesting birds, it is so remarkable as to be worthy of mention here.

Instances of a pair of birds-in addition to the gregarious varietiesoccupying the nest which actually adjoins that of their neighbours are not uncommon; neither is it unusual for one pair of birds to oust another from the home they have so laboriously prepared, and perhaps to sit upon the eggs of the original owner, in addition to their own. Whilst cases in which a bird deposits her egg, or eggs, in the nest of another are quite common.

But, as far as my experience goes, the Robin-Wagtail episode is unique; in fact, had the news of it emanated from a less reliable source than Captain Douglas English, I am afraid that I should not have believed it; and should probably have accounted for the mixed eggs by supposing that some one had been trying an experiment.

However, investigation proved that the nest actually was tenanted by two pairs of birds, all of whom seemed anxious to share the domestic responsibilities.

When we first arrived at the place, we found that the female Robin was sitting on the nest. We quietly put her off, and her departure revealed two newly hatched young Wagtails, one newly hatched young Robin, one Wagtail's egg, and two Robins' eggs. We were told that the nest originally contained four eggs of the Robin, and four of the Wagtail, but that one of each 
kind had disappeared-perhaps to swell the collection of some budding oologist.

We examined the nest carefully, and it certainly seemed a hybrid structure, being composed of dead ivy leaves, some grass, one or two tufts of red flannel, and an inner lining of wool and fine grasses.

After our inspection we retired to a bank a few yards away, and, sitting down to await events, soon had the satisfaction of at least seeing the Robin return to the business of incubation. But of the Wagtail we saw not a sign, although we waited for some hour or so. In fact we at length began to grow sceptical and to consider the possibility of some one having placed the Wagtail's eggs in the Robin's nest for fun, and the chance of the Wagtail having been seen near the nest in search of flies. And yet there remained the fact that the story of both birds occupying the nest had been told to us by three independent eye-witnesses as to whose bona fides there could be no possible question.

In the evening of the following day my brother and I again visited the place, and to our delight-and I must confess astonishment-found both the Robin and the Wagtail sitting on the nest : the Robin underneath, and the Wagtail rather to the side of the nest and covering the Robin's tail.

On our third visit we found that all four birds - the pair of Wagtails, and the pair of Robins were engaged in feeding the curious family, and delivering the food indiscriminately as far as we could make out. On one occasion both Wagtails were on the nest together, and had the situation been better lighted we should have had no difficulty in obtaining photographs; for in the course of an hour the Wagtails came to the nest thirteen times.

The Robins seemed veryshy of their partners, andalthough they occasionally settled for a moment on the nest and hurriedly poked some food down the first gaping mouth that presented itself, they were obviously in a state of nervous tension.

On the following day it was the Robins, curiously enough, which were chiefly in evidence, for they paid fifteen visits to the nest between six and six-thirty, whilst the Wagtails only put in an appearance three times-and that during a period of nearly three hours.

Next day, like the preceding one, turned out to be a Robin day : for although we watched the nest for some hours, and saw the Robins continually feeding the young ones, we did not once see the Wagtails visit the nest. They hovered quite near to it, and dashed like little hawks at the Robins when they saw them offering food to the youngsters.

It was curious to see Robins reduced to such a state of fear as were those two, for when the Wagtails perched near the nest they kept at a prudent distance, and waited until the coast was clear before venturing to feed the young ones.

Unhappily this strange 'menage' was fated to an untimely end : for a 
cat pulled the nest out, and carried off its helpless occupants. And, incidentally by so doing, prevented any further observation of the most remarkable episode in bird-life that $\mathbf{I}$ have ever witnessed.

A curious instance of a Carrion Crow's determination to rear a normal family rather than a single young one is contained in the following account, which concerns a nest which I discovered in the days when I was an ardent egg collector.

On April 23, I had climbed to a Crow's nest, over the edge of which I had seen the Crow's tail protruding, and to my joy found it contained four extraordinarily beautiful eggs.

These, I need hardly say, I took away with me, and flattered myself that I had secured a particularly fine clutch. On May 6 of the same year I again passed under the elm-tree, and once more noticed the tip of the Crow's tail projecting from the nest. Yet again I set to work to climb the tree to see if she had laid a second clutch, and found that the nest this time actually contained five eggs.

This seemed to me incomprehensible, for when a bird has its first clutch of eggs destroyed, or taken, it almost invariably lays a smaller clutch-if a second trial is attempted.

On returning home, however, I blew the eggs, and found that whilst four of them were newly laid, the fifth was hard-set-proving that the Crow, dissatisfied with the idea of a single youngster, had during the fortnight that had elapsed, produced another four eggs-making the total equal to that of the original number laid.

And at about the same time I found a Missel Thrush's nest containing eggs whose history to me at least, seemed inexplicable. The number of eggs which the Missel Thrush lays is normally four; this nest however contained no less than eight eggs, four of which were quite fresh; two were on the point of hatching, and two were bad. One can only suppose that either the Missel Thrush was disturbed, and became sceptical as to whether the original four would hatch, and so laid a second consignment-or that the original female was killed; and the male procured another, who added her cggs to those already in the nest, and incubated them all.

The second solution is not very probable however, for in that case four of the eggs would in all probability have been bad.

And whilst on the subject of Missel Thrushes, I should like to relate an incident concerning one of them-an incident which also illustrates the cxtraordinary speed with which a Sparrow Hawk dashes at his victim.

I had noticed in a low oak-tree, a Missel Thrush's nest, and from below could see that it was littered with small feathers. Supposing that the bird had died whilst covering her eggs, and that the feathers had become detached from her decomposing body. I climbed up to investigate - to find that the 


\section{WILD LIFE IN THE TREE TOPS}

unhappy Missel Thrush was indeed dead on her eggs, minus her head, which had obviously been swept clean from her body.

Those who have seen a Sparrow Hawk come down like a flash, pick up a bird in its stride, and carry it away, will realize that it is the only creature who could have done this thing. So instantaneous must have been the death of the Missel Thrush that her body had not moved; it was covering the eggs with slightly spread wings, and puffed-out breast feathers, exactly as though it were alive.

Such tragedies not infrequently occur; and I am reminded of an instance which occurred during the past summer, whilst I was cinematographing the Rooks.

I was walking near the Rookery one afternoon towards the end of May, when I noticed a Rook fluttering on the top of a tall willow-tree. For a while I stood and watched it without realizing what was amiss, for it first of all fluttered violently, without apparently making any headway, and then sat up on the branch again.

As I drew nearer the Rook repeated this extraordinary movement and it occurred to me that perhaps it had had its leg broken by one of the party who were Rook-shooting some days before, and got the limb caught somehow in a fork of a branch.

So I proceeded to climb the tree with the idea of discovering the reason of the Rook's strange behaviour, and found that, somehow or other, it had got some sheep's wool twisted around its leg, just above the foot, and that this in turn was twisted firmly round one of the topmost branches of the tree. I need hardly say that I set the terrified Rook free, and am confident that, had I not done so, he would undoubtedly have shared the fate of the numerous small birds that have become entangled in horse-hair.

It may not be generally known that it is the habit of the Mallard, or Wild Duck, in certain localities to nest in trees as well as upon the ground, and one is inclined to wonder whether the peculiarity is due to an instinctive fear of the foxes. In any case it seems to originate, at least in some districts, where foxes are numerous, and to continue after they have been exterminated.

In one district with which I am particularly familiar it is not at all unusual to find a Wild Duck's nest in one of the hollow oak or elm-trees with which the place abounds; and in spite of the fact that the young ducks when hatched have to risk a tumble to the ground, they generally seem to get safely away.

During the eariy summer of 1914, I happened to be staying in this district, and went one day to investigate a hollow elm which in the previous year contained the nest of a Barn Owl. I climbed the tree very quietly, as I thought that I might be able to peep in on the owl, and, if she were sitting, to retire without disturbing her. I received a rude shock when, just as I was going to peep stealthily into the hole, a Wild Duck, with a whirr of wings, dashed out, 


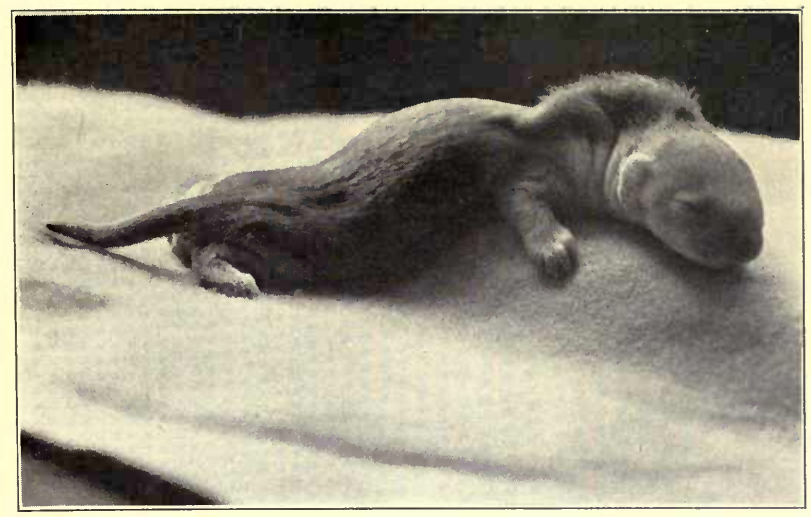

THE "SCRUFF" OF THE

YOUNG STOAT

FROM THE

STOAT'S I.ARDER

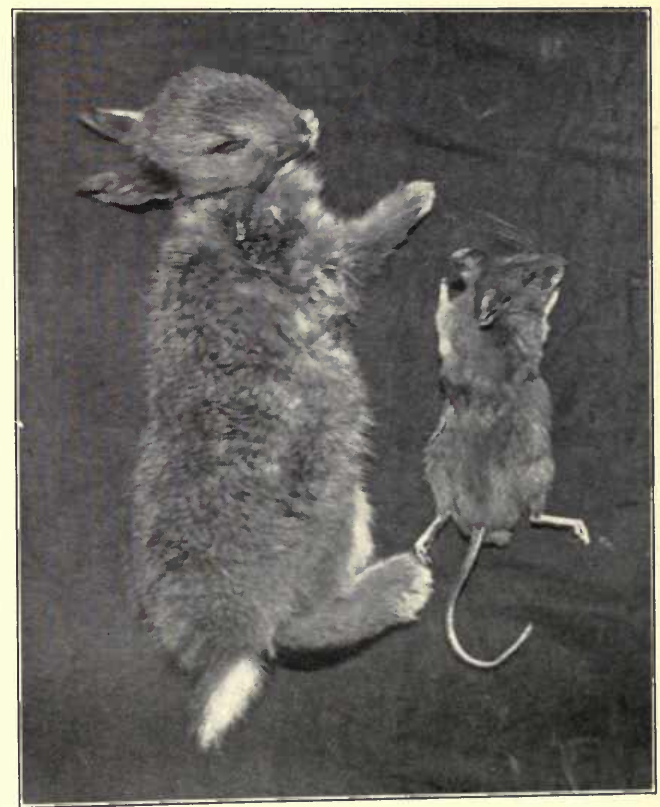



hit me in the face, and nearly succeeded in dislodging me! Inside the hollow was the duck's nest, with some six or eight eggs lying amid the down.

But the hollow tree had yet further surprises in store for me, for on visiting it some weeks later, and climbing up with the resolve not to jump if the duck lashed out I received perhaps an even greater shock than before. For, as I peered in to look on to the nest, I was met, not by the form of the flying duck, but by an angry 'tchak' that issued from somewhere just inside the hole.

As I gazed within, and my eyes grew accustomed to the light, I thought that the slight movements I could distinguish were made by some young ducks; then it seemed that a little form I could make out was a weasel with its head buried in the dry chips of wood and dust at the bottom of the hole.

Presently the little creature-which I now saw was a stoat-raised its head, and, advancing to within six inches of my face, uttered its spitting 'tchak' -and retired again up the hollow trunk.

Presently I saw its head appear from a hole some 12 feet further up the tree-another entrance to the 'chimney' which led up from its nest.

I knew that the chimney existed, for in the previous year two Barn Owls had flown into the hole where the stoat now had her nest, and had emerged from the upper exit. I thereupon climbed up to this top hole, and, pcering within, could clearly see the stoat inside. Three or four times she came to the entrance of the hole-which by this time smelt strongly of offensive odour which the stoat is capable of emitting-and 'spat' at me; once when I had my face close to the hole.

On climbing down again, and once more looking into the nest hole, I thought that I could see what seemed to be the head of a small rabbit near the nest, but on reaching and withdrawing it found that it was a young stoat, which its mother had been covering with rabbit fur when I first looked in.

I discovered that there were altogether five of these young stoats hidden amongst the duck's down and rabbit fur in the corner of the hole.

Such young stoats-as shown in one of the illustrations-are provided with a 'scruff' at the back of the neck, which consists of loose skin covered with comparatively long hair, the hair being of a much redder colour than that with which the rest of the body is covered.

This 'scruff' is an instance of the manner in which Nature provides for the peculiarities of her children; for it happens that stoats are very much addicted to the habit of carrying their young from place to place, and in fact seldom allow them to remain in one particular spot for any length of time.

That stoats are efficient tree-climbers, I have long had reason to know, for I remember in my school-days climbing up to a squirrel's nest in a tall oak-tree in which I expected to find a family of squirrels, and my amazement when a stoat darted out! My friends at the bottom of the tree thought that 
we might be able to catch it-but the stoat avoided our clumsy efforts with the greatest ease, and, jumping from the top of a tall bough, dropped like a piece of wire to earth, and disappeared.

And I have also seen a stoat sitting on the side of a thrush's nest in a small elder-tree, and in spite of the clamour of a collection of the small birds of the neighbourhood, calmly eating the young thrushes!

An intimate friend of mine, and a keen observer, who has had unusual opportunities of studying the habits of stoats, tells me that he once came upon one of them carrying a young one in her mouth, which she dropped when he gave chase to her. Knowing the extraordinary devotion of the female stoat to her young, he decided to wait to see if she would return to continue the work in which she had been surprised. Having waited for three hours, he decided to waste no more time, and as he rose to go, was on the point of proceeding homeward when he sighted the stoat going in the same direction as when he had first seen her, and with yet another youngster in her mouthonly this time she was making a detour across the middle of an open sevenacre field! And while he had been waiting she had doubtless moved other members of the family in the same manner.

On another occasion he discovered a thrush's nest in a hawthorn hedge which contained the half-eaten remains of a young rabbit-clearly the work of a stoat. A little further on was another thrush's nest beautifully lined with rabbit's fur, in which no doubt the stoat basked on sunny days : yet a third nest, also a thrush's, contained four eggs, which were covered with still further remains of the stoat's work-in the shape of half a small rabbit.

But perhaps his most extraordinary expericnce was when, attracted by the frantic screams of a Green Woodpecker, he approached a tall elm-tree, and saw a stoat climbing up to the Woodpecker's nesting-hole. He stood motionless whilst the stoat reached and entered the hole. Presently it disappeared inside, but soon reappeared again with one of the Woodpecker's eggs in its mouth. This was dropped outside the hole, and of course smashed on the way down. Again the stoat disappeared into the hole and again appeared with another Woodpecker's egg. This time, however, he was greeted ly a charge of shot which effectually ended his career.

On the same day that we discovered the young stoats in the duck's nest we made another extraordinary discovery-that of a duck sitting on an old Heron's nest. The Heron's nest was at the top of a fairly high oak-tree, and contained a clutch of the Mallard's eggs. Unhappily, it was in an impossible position to photograph, though I have always regretted not being able to secure a pictorial record of such an unusual nesting-place.!

I have altogether spent a good deal of time among the Herons, and so have perhaps undergone more queer experiences in their company than elsewhere. 
In the summer of 1920 I constructed an observation post overlooking a Heron's nest; and, as explained in the chapter on Herons, arranged that its construction should cover a period of some weeks. Consequently, when I ultimately decided to try for photographs, I had not visited the place for some days.

I was, nevertheless, surprised to find inside it, on the small piece of sacking that sagged down behind my branch-seat, a small handful of twigs, and on them a Stock-Dove's egg!

As I could not possibly sit down, as things were, without smashing the egg, I picked up both it and the nest, and placed them in my pocket. When I had at length satisfactorily arranged things, and was waiting for the return of the Heron, I decided, in order to avoid accidentally crushing the egg, to put it in another sag in the canvas on my right. So, withdrawing most of the twigs from my pocket, I roughly arranged them, and then laid the egg in position.

Some time later, when my thoughts were concentrated on the young Herons opposite, I heard a bird fluttering about amongst the withered branches with which the observation post was camouflaged, and guessed at once that it was the Stock-Dove, who, since I had closed the entrance after getting inside, was unable to get in!

Its failure, however, was certainly not due to lack of persistence, for it fluttered to the back and front and sides, endeavouring to find an entrance; and eventually managed to squeeze in between the edge of the canvas and a branch of the tree.

For some time it stood, with head on one side, and stretched forward, trying to make out, in the darkness, what kind of a thing I was.

I need hardly say that I sat absolutely still, for I did not want to scare the bird, and in fact, welcomed a visitor to brighten my dull hours of waiting. And at length the little pigeon, having satisfied itself that all was well, stepped forward to where I had placed the egg.

To my surprise he-for it was presumably the male bird-began to coo heartily, and placing one foot on the egg, moved it about as though testing its quality, or admiring its shape; then he lowered his head, and nibbled at it with his beak, perhaps to satisfy himself as to its really being the right one.

And then, walking to the hole by which he had entered, he forced himself through the opening, and fluttered on to a branch outside.

He was evidently dissatisfied with the nest, for, having fluttered about once more among the decorations of the observation post, he again returned, this time with a tiny piece of twig-about $1 \frac{1}{2}$ inches long-in his beak!

This fine contribution having been laid by the side of the egg, the little pigeon commenced to coo proudly; evidently well pleased with what he had done. 
But at this moment-to my consternation-I heard the young Herons in ' $m y$ ' nest begin their excited 'chun-chun' noise, and for a moment was at a loss as to how I had best act. For it is quite certain that had I made an attempt to turn the handle of the cinema camera, the pigeon would have dashed out in a frenzy of fear-and it is equally certain that such an exit would have caused the Heron to leave her family as unceremoniously.

So, stealthily reaching forward in the darkness with my right hand, and following the move with a sudden grab, I had made captive the astonished pigeon before she had even time to flutter! And transferring her to my left hand, I sat in readiness for the coming of the Heron.

And when the time of tension had passed, and the Heron was gone off again, I opened the entrance flap and threw the pigeon out into the air.

And the incident did not end there, for when I next visited my hide the little pile of twigs supported two eggs, whilst another pair of Doves had made a second nest-in the place where the first had been-and laid an egg on it.

I once missed an extraordinary photograph from this observation post which would have shown a magpie searching for fragments of food beneath the Heron's nest ; only she persisted in keeping just out of the picture. And then I wish I had been able to get a record of a family of five fully fledged young jays, who perched on a branch outside my observation post, within two feet of my head, and were fed on insects by their devoted parents.

But there is much that one just misses in the way of bird photographs.

And there are occasions when one secures by pure accident something of particular interest, and of unusual pictorial value.

An instance of which is, perhaps, the following-and final-story which, like so many of the others, occurred 'before the war.'

We were trying for a photograph of the mature Heron, and when I had focused the camera on a nest with certain pictorial qualities, my brother, who had frequently performed similar services, agreed to await the return of the bird.

Whilst I enjoyed myself out on the marshes, he patiently waited on, without seeing a sign of the parent Herons. As time went by he began to feel a little sceptical as to whether any good results would be achieved; when a rabbit, galloping through the wood, and all unconscious of him, or his apparatus, blundered into the string and made an exposure!

I was at the time somewhat annoyed at being called back; and at having to climb the tree to rearrange things for such a ridiculous reason. But the rabbit was quite forgiven when, on developing the negative, I discovered that it had contributed towards my collection what is-without doubt-one of our most successful achievements. 

UNIVERSITY OF CALIFORNIA LIBRARY

Los Angeles

This book is DUE on the last date stamped below. 
$9 / 22 \gamma$

UC SOUTHERN REGIONAL LIBRARY FACULTY

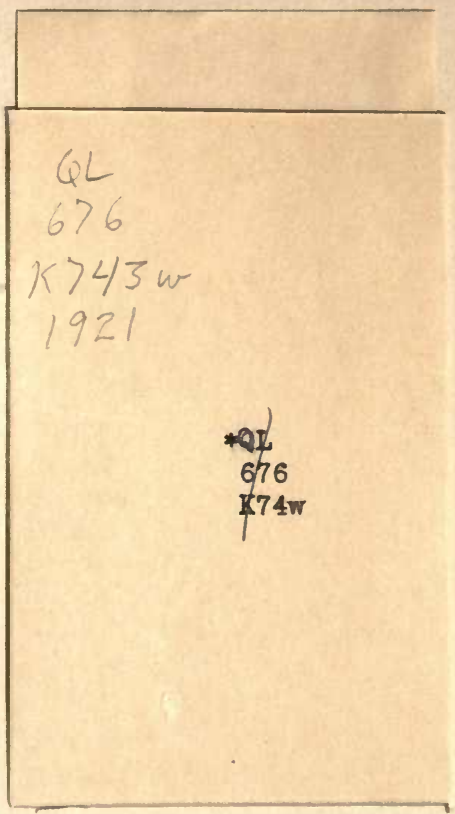


